\title{
Experimental constraints on the relative stabilities of the two systems monazite-(Ce) - allanite-(Ce) - fluorapatite and xenotime-(Y) - (Y,HREE)-rich epidote - (Y,HREE)-rich fluorapatite, in high $\mathrm{Ca}$ and $\mathrm{Na}-\mathrm{Ca}$ environments under $\mathrm{P}-\mathrm{T}$ conditions of 200-1000 MPa and $450-750{ }^{\circ} \mathrm{C}$
}

\author{
Bartosz Budzyń $^{1}$ • Daniel E. Harlov ${ }^{2,3}$ • Gabriela A. Kozub-Budzyń ${ }^{4}$ • Jarosław Majka ${ }^{4,5}$
}

Received: 14 September 2015 / Accepted: 17 August 2016/Published online: 6 September 2016

(C) The Author(s) 2016. This article is published with open access at Springerlink.com

\begin{abstract}
The relative stabilities of phases within the two systems monazite- $(\mathrm{Ce})$ - fluorapatite - allanite- $(\mathrm{Ce})$ and xenotime-(Y) - (Y,HREE)-rich fluorapatite - (Y,HREE)-rich epidote have been tested experimentally as a function of pressure and temperature in systems roughly replicating granitic to pelitic composition with high and moderate bulk $\mathrm{CaO} / \mathrm{Na}_{2} \mathrm{O}$ ratios over a wide range of $\mathrm{P}-\mathrm{T}$ conditions from 200 to $1000 \mathrm{MPa}$ and 450 to $750{ }^{\circ} \mathrm{C}$ via four sets of experiments. These included (1) monazite-(Ce), labradorite, sanidine, biotite, muscovite, $\mathrm{SiO}_{2}, \mathrm{CaF}_{2}$, and $2 \mathrm{M} \mathrm{Ca}(\mathrm{OH})_{2}$; (2) monazite-(Ce), albite, sanidine, biotite, muscovite, $\mathrm{SiO}_{2}, \mathrm{CaF}_{2}, \mathrm{Na}_{2} \mathrm{Si}_{2} \mathrm{O}_{5}$, and $\mathrm{H}_{2} \mathrm{O}$; (3) xenotime-(Y), labradorite, sanidine, biotite, muscovite, garnet, $\mathrm{SiO}_{2}, \mathrm{CaF}_{2}$, and $2 \mathrm{M} \mathrm{Ca}(\mathrm{OH})_{2}$; and (4)
\end{abstract}

Editorial handling: L. Nasdala

Electronic supplementary material The online version of this article (doi:10.1007/s00710-016-0464-0) contains supplementary material, which is available to authorized users.

Bartosz Budzyń

ndbudzyn@cyf-kr.edu.pl

1 Institute of Geological Sciences, Polish Academy of Sciences, Research Centre in Kraków ING PAN, Senacka 1, PL-31002 Kraków, Poland

2 GeoForschungsZentrum Potsdam, Telegrafenberg, D-14473 Potsdam, Germany

3 Department of Geology, University of Johannesburg, P.O. Box 524, Auckland Park 2006, South Africa

4 AGH University of Science and Technology, Faculty of Geology, Geophysics and Environmental Protection, al. A. Mickiewicza 30, PL-30059 Krakow, Poland

5 Department of Earth Sciences, Uppsala University, Villavägen 16, SE-752 36 Uppsala, Sweden
xenotime-(Y), albite, sanidine, biotite, muscovite, garnet, $\mathrm{SiO}_{2}, \mathrm{CaF}_{2}, \mathrm{Na}_{2} \mathrm{Si}_{2} \mathrm{O}_{5}$, and $\mathrm{H}_{2} \mathrm{O}$. Monazite-(Ce) breakdown was documented in experimental sets (1) and (2). In experimental set (1), the $\mathrm{Ca}$ high activity (estimated bulk $\mathrm{CaO} / \mathrm{Na}_{2} \mathrm{O}$ ratio of 13.3) promoted the formation of REE-rich epidote, allanite-(Ce), REE-rich fluorapatite, and fluorcalciobritholite at the expense of monazite-(Ce). In contrast, a bulk $\mathrm{CaO} /$ $\mathrm{Na}_{2} \mathrm{O}$ ratio of $\sim 1.0$ in runs in set (2) prevented the formation of REE-rich epidote and allanite-(Ce). The reacted monazite-(Ce) was partially replaced by REE-rich fluorapatite-fluorcalciobritholite in all runs, REE-rich steacyite in experiments at $450{ }^{\circ} \mathrm{C}, 200-1000 \mathrm{MPa}$, and $550^{\circ} \mathrm{C}, 200$ $600 \mathrm{MPa}$, and minor cheralite in runs at $650-750^{\circ} \mathrm{C}, 200$ $1000 \mathrm{MPa}$. The experimental results support previous natural observations and thermodynamic modeling of phase equilibria, which demonstrate that an increased $\mathrm{CaO}$ bulk content expands the stability field of allanite-(Ce) relative to monazite-(Ce) at higher temperatures indicating that the relative stabilities of monazite- $(\mathrm{Ce})$ and allanite- $(\mathrm{Ce})$ depend on the bulk $\mathrm{CaO} /$ $\mathrm{Na}_{2} \mathrm{O}$ ratio. The experiments also provide new insights into the re-equilibration of monazite-(Ce) via fluid-aided coupled dissolution-reprecipitation, which affects the Th-U-Pb system in runs at $450{ }^{\circ} \mathrm{C}, 200-1000 \mathrm{MPa}$, and $550{ }^{\circ} \mathrm{C}, 200-600 \mathrm{MPa}$. A lack of compositional alteration in the $\mathrm{Th}, \mathrm{U}$, and $\mathrm{Pb}$ in monazite-(Ce) at $550{ }^{\circ} \mathrm{C}, 800-1000 \mathrm{MPa}$, and in experiments at $650-750{ }^{\circ} \mathrm{C}, 200-1000 \mathrm{MPa}$ indicates the limited influence of fluid-mediated alteration on volume diffusion under high $\mathrm{P}-\mathrm{T}$ conditions. Experimental sets (3) and (4) resulted in xenotime-(Y) breakdown and partial replacement by (Y,REE)rich fluorapatite to Y-rich fluorcalciobritholite. Additionally, (Y,HREE)-rich epidote formed at the expense of xenotime-(Y) in three runs with $2 \mathrm{M} \mathrm{Ca}(\mathrm{OH})_{2}$ fluid, at $550{ }^{\circ} \mathrm{C}, 800 \mathrm{MPa} ; 650{ }^{\circ} \mathrm{C}, 800 \mathrm{MPa}$; and $650{ }^{\circ} \mathrm{C}, 1000 \mathrm{MPa}$ similar to the experiments involving monazite-(Ce). These results confirm that replacement of xenotime-(Y) by (Y,HREE)- 
rich epidote is induced by a high $\mathrm{Ca}$ bulk content with a high $\mathrm{CaO} / \mathrm{Na}_{2} \mathrm{O}$ ratio. These experiments demonstrate also that the relative stabilities of xenotime-(Y) and (Y,HREE)-rich epidote are strongly controlled by pressure.

Keywords Monazite-(Ce) $\cdot$ Xenotime-( $(\mathrm{Y}) \cdot$ Allanite- $(\mathrm{Ce})$. Epidote $\cdot$ Fluorapatite $\cdot$ Fluorcalciobritholite $\cdot$ Rare earth elements $\cdot$ Experimental petrology

\section{Introduction}

Monazite [(LREE,Th,U)PO $\mathrm{P}_{4}$ ], xenotime-(Y) [(Y,HREE)PO ${ }_{4}$ ], fluorapatite $\left[(\mathrm{Ca}, \mathrm{LREE}, \mathrm{Si}, \mathrm{Na})_{5}\left(\mathrm{PO}_{4}\right)_{3} \mathrm{~F}\right]$, and allanite $\left[(\mathrm{Ca}, \mathrm{REE})\left(\mathrm{Al}_{2}, \mathrm{Fe}^{2+}\right)\left(\mathrm{Si}_{2} \mathrm{O}_{7}\right)\left(\mathrm{SiO}_{4}\right) \mathrm{O}(\mathrm{OH})\right]$ are common accessory minerals in various types of igneous, metamorphic, and sedimentary rocks and represent the principal hosts of rare earth elements (REEs) in the Earth's crust. They are widely used as geochronometers, including $\mathrm{U}-\mathrm{Pb}$ and $\mathrm{Th}-\mathrm{U}-\mathrm{Pb}$ dating of monazite (Williams et al. 2007) and xenotime-(Y) (Hetherington et al. 2008), Lu-Hf, U-Pb, fission track and (U-Th)/He dating of apatite (Chew and Spikings 2015), and U-Pb dating of allanite (Gregory et al. 2007; Darling et al. 2012). Distribution of $Y$ between co-existing monazite and xenotime-(Y) (Gratz and Heinrich 1997; Heinrich et al. 1997; Andrehs and Heinrich 1998) or monazite and garnet (Pyle et al. 2001) can be utilized as geothermometers. In addition to these important applications, monazite, xenotime-(Y), apatite, and allanite can also be used for studying metasomatic processes; the nature of the fluids responsible for these processes (Putnis 2009; Budzyń et al. 2011; Harlov et al. 2011; Harlov 2015); and to constrain timing of mineralfluid interactions (Williams et al. 2011; Villa and Williams 2013).

The relative stabilities of monazite, allanite, and fluorapatite are of particular interest in studies of igneous and metamorphic processes. For example, in metamorphosed rocks of granitic or pelitic composition, monazite-(Ce) alteration and breakdown involve formation of complex textures involving fluorapatite, allanite-(Ce), epidote $\left[\mathrm{Ca}_{2}\left(\mathrm{Al}_{2}, \mathrm{Fe}^{3+}\right)\left(\mathrm{Si}_{2} \mathrm{O}_{7}\right)\left(\mathrm{SiO}_{4}\right) \mathrm{O}(\mathrm{OH})\right]$, and $\mathrm{ThSiO}_{4}$ or $\mathrm{ThO}_{2}$, mediated by a fluid with high $\mathrm{Ca}$ and $\mathrm{F}$ activities (Broska and Siman 1998; Finger et al. 1998; Broska et al. 2005; Petrík et al. 2006; Janots et al. 2008; Ondrejka et al. 2012). More rarely, monazite-(Ce) can be replaced by secondary fluorapatite and monazite, but not allanite-(Ce) (Rasmussen and Muhling 2007; Budzyń et al. 2010). The diversity of products is strictly related to the P-T conditions, bulk rock composition, and composition of the fluid. Several experimental studies have determined the stabilities of monazite-(Ce), allanite-(Ce), and fluorapatite relative to each other. Experiments at $450-500{ }^{\circ} \mathrm{C}$ and $450-610 \mathrm{MPa}$ utilizing silicate mineral assemblages and various fluids, including
$\mathrm{H}_{2} \mathrm{O}, 2 \mathrm{M} \mathrm{NaOH}, 2 \mathrm{M} \mathrm{KOH}, 1 \mathrm{M} / 2 \mathrm{M} \mathrm{Ca}(\mathrm{OH})_{2}, 1 \mathrm{M} \mathrm{HCl}$, $\mathrm{NaCl}+\mathrm{H}_{2} \mathrm{O}, \mathrm{KCl}+\mathrm{H}_{2} \mathrm{O}, \mathrm{CaCl}_{2}+\mathrm{H}_{2} \mathrm{O}, \mathrm{CaCO}_{3}+\mathrm{H}_{2} \mathrm{O}$, and $\mathrm{Na}_{2} \mathrm{Si}_{2} \mathrm{O}_{5}+\mathrm{H}_{2} \mathrm{O}$, tested the stability of monazite- $(\mathrm{Ce})$ relative to allanite-(Ce) and fluorapatite as a function of P-T-X conditions (Budzyń et al. 2011). Monazite-(Ce) partially broke down to fluorapatite and/or britholite in most of the experiments. In the presence of Ca-bearing fluids, allanite-(Ce) and REE-rich epidote also formed. In the experiment at $450{ }^{\circ} \mathrm{C}$ and $450 \mathrm{MPa}$ with $\mathrm{Na}_{2} \mathrm{Si}_{2} \mathrm{O}_{5}+\mathrm{H}_{2} \mathrm{O}$, alteration of monazite-(Ce) via fluid-mediated coupled dissolutionreprecipitation resulted in the resetting of monazite Th-U-Pb clock far below the diffusional closure temperature (Williams et al. 2011). Recently, the stability of monazite-(Ce) was tested in the presence of silicate mineral assemblages under conditions of $250-350{ }^{\circ} \mathrm{C}$ and $200-400 \mathrm{MPa}$ (Budzyń et al. 2015). Monazite-(Ce) was stable in the presence of $2 \mathrm{M} \mathrm{Ca}(\mathrm{OH})_{2}$, where some fluorapatite to fluorcalciobritholite $\left[(\mathrm{Ca}, \mathrm{REE})_{5}\left(\mathrm{SiO}_{4}, \mathrm{PO}_{4}\right)_{3} \mathrm{~F}\right]$ formed, but no allanite. The presence of $\mathrm{Na}_{2} \mathrm{Si}_{2} \mathrm{O}_{5}+\mathrm{H}_{2} \mathrm{O}$ promoted the strong alteration of the monazite-(Ce) and the formation of steacyite $\left[(\mathrm{K}, \square)(\mathrm{Na}, \mathrm{Ca})_{2}(\mathrm{Th}, \mathrm{U}) \mathrm{Si}_{8} \mathrm{O}_{20}\right]$ enriched in $\mathrm{REE}$, and fluorcalciobritholite. Furthermore, fluid induced monazite-(Ce) alteration promoted mass transfer with partial removal of $\mathrm{Th}, \mathrm{U}$, and $\mathrm{Pb}$ via fluid-mediated coupled dissolution-reprecipitation resulting in significant disturbance of the original ages without resetting in contrast to $450^{\circ} \mathrm{C}$ and $450 \mathrm{MPa}$ experiment in Williams et al. (2011).

These experiments were based on available data from monazite-allanite relations in metamorphosed granites and pelites (Broska and Siman 1998; Finger et al. 1998; Janots et al. 2006), and the thermodynamic modeling of the relative stabilities of monazite-(La) and dissakisite-( $\mathrm{La}), \mathrm{Mg}$ equivalent of allanite (Janots et al. 2007). Later thermodynamic modeling by Spear (2010), which utilized the average whole rock metapelite data of Shaw (1956), showed that increasing the $\mathrm{CaO}$ content from 2.17 to $4.34 \mathrm{wt} . \%$ shifts the transition of allanite-(Ce) to monazite-(Ce) from $\sim 400$ $550{ }^{\circ} \mathrm{C}$, depending on a pressure, to $\sim 480{ }^{\circ} \mathrm{C}$ at $200 \mathrm{MPa}$ and $\sim 750{ }^{\circ} \mathrm{C}$ at $1000 \mathrm{MPa}$, thereby expanding the allanite-(Ce) stability field. Fluorapatite was stable over the entire calculated P-T range (100-1100 MPa and 350$800{ }^{\circ} \mathrm{C}$ ) considered. In the experiments of Budzyń et al. (2011), those with a significantly increased bulk $\mathrm{CaO}$ content ( 11.3-17.7 wt.\%) resulted in allanite-(Ce) and fluorapatitebritholite formation at $450-500{ }^{\circ} \mathrm{C}$ and $400-610 \mathrm{MPa}$ in agreement with Spear's (2010) thermodynamic modeling.

Xenotime- $(\mathrm{Y})$ is recognized as a robust geochronometer, which is resistant to alteration (Rasmussen 2005). In addition, volume diffusion of $\mathrm{Pb}$ has been experimentally demonstrated to be slower than in zircon or monazite (Cherniak 2006). Similar to monazite-(Ce), fluid-mediated alteration has also led to the replacement of xenotime-(Y) by corona-like textures including (Y,HREE)-rich fluorapatite and (Y,HREE)-rich 
epidote in granitic rocks (Broska et al. 2005; Broska and Petrík 2015) or fluorapatite and hingganite-(Y) in pegmatite (Majka et al. 2011). The P-T conditions for such alterations are not well constrained. During progressive metamorphism of pelites, xenotime-(Y) breaks down before the growth of garnet. This is then followed by the breakdown of HREE-rich clinozoisite to xenotime-(Y) at $560-610{ }^{\circ} \mathrm{C}$, depending on bulk composition of rock, particularly the bulk $\mathrm{CaO} / \mathrm{Na}_{2} \mathrm{O}$ ratio (Janots et al. 2008). Because xenotime-(Y) is less abundant than monazite in nature, our knowledge about its stability during metamorphism, particularly in relation to (Y,HREE)rich epidote and (Y,HREE)-rich fluorapatite, is still limited.

In this work, the relative stabilities of monazite-(Ce), allanite-(Ce), and fluorapatite are explored in a series of experiments which expand on the previous experiments of Budzyń et al. (2011) to a broader range of P-T conditions at 200 to $1000 \mathrm{MPa}$ and 450 to $750{ }^{\circ} \mathrm{C}$. The study aims to determine (i) if allanite-(Ce) and/or fluorapatite will form at the expense of monazite- $(\mathrm{Ce})$ in experiments utilizing monazite-(Ce) plus a silicate mineral assemblage and a $2 \mathrm{M}$ $\mathrm{Ca}(\mathrm{OH})_{2}$ fluid or a $\mathrm{Na}_{2} \mathrm{Si}_{2} \mathrm{O}_{5}+\mathrm{H}_{2} \mathrm{O}$ fluid over the above P-T range; and (ii) the impact of fluid-mediated alteration on the remobilization of $\mathrm{Th}, \mathrm{U}$, and $\mathrm{Pb}$ in the monazite-(Ce) structure in the presence of a $\mathrm{Na}_{2} \mathrm{Si}_{2} \mathrm{O}_{5}+\mathrm{H}_{2} \mathrm{O}$, with regards to its impact on geochronology. Starting mixes with both fluids had an elevated bulk $\mathrm{Ca}$ content that should promote fluorapatite and allanite-(Ce) formation. A simultaneous set of parallel experiments for xenotime-(Y) were aimed at determining the P-T stability relations between xenotime-(Y), (Y,HREE)-rich epidote, and (Y,HREE)-rich fluorapatite. This study also aims to estimate to what degree $Y+$ REE incorporation into epidote-group minerals is a function of fluid composition or P-T conditions or both in a REE-dominated system.

\section{Experimental and analytical methods}

\section{Experiments}

Experiments were performed utilizing cold-seal autoclaves on a hydrothermal line and the piston-cylinder apparatus. Pressures and temperatures ranged from 200 to $1000 \mathrm{MPa}$ and from 450 to $750{ }^{\circ} \mathrm{C}$. Each run involved four sets of experiments, two for monazite-(Ce) and two for xenotime-(Y), each one corresponding to two different fluids, $2 \mathrm{M} \mathrm{Ca}(\mathrm{OH})_{2}$ or $\mathrm{Na}_{2} \mathrm{Si}_{2} \mathrm{O}_{5}+\mathrm{H}_{2} \mathrm{O}$ (Table 1). In each set of experiments, coarse grains $(50-250 \mu \mathrm{m})$ of monazite- $(\mathrm{Ce})$ and xenotime- $(\mathrm{Y})$ were used to explore reactions, primarily focused on the partial replacement of monazite-(Ce) and xenotime-(Y) by (Y,REE)-enriched epidote and fluorapatite. In order to effect these reactions in an approximation of a metapelitic, geochemical environment, quartz, albite, biotite, garnet, labradorite, muscovite, $\mathrm{K}$-feldspar, and $\mathrm{CaF}_{2}$ from diverse sources were added to the system. These provided the materials necessary for the reactions: monazite- $(\mathrm{Ce})+$ annite + quartz $+\mathrm{Ca}+\mathrm{F}$ (in fluid-I) $=$ fluorapatite + allanite $-(\mathrm{Ce})+$ fluid-II (Broska and Siman 1998), and xenotime-(Y) + annite + anorthite + fluid $=($ Y,HREE $)$-rich apatite $+($ Y,HREE $)$-rich epidote + muscovite (Broska et al. 2005). These experiments were not aimed at achieving thermobarometric equilibria between a group of silicate minerals from a diverse set of sources. Rather, these coarse grains of monazite-(Ce) and xenotime-(Y) were used to induce (Y,REE)-bearing epidote and apatite reaction textures to form, which is the chief focus of this study.

The Burnet monazite-(Ce) used in experiments originates from a pegmatite from Burnet County, Texas, USA. This monazite-(Ce) $\left(10.18-12.54\right.$ wt. $\% \mathrm{ThO}_{2} ; 0.28-0.40$ wt.\% $\mathrm{UO}_{2} ; 0.51-0.65$ wt. $\% \mathrm{PbO}$; see supplementary Table S1 for average composition) was selected to test the relative mobility of $\mathrm{Y}, \mathrm{REE}, \mathrm{Th}, \mathrm{U}$, and $\mathrm{Pb}$. A fragment of the Burnet monazite-(Ce) was crushed and sieved to a $50-250 \mu \mathrm{m}$ fraction. Optically clear to slightly foggy, reddish-brown grains were hand picked out under a binocular microscope. The separated grains were washed in ethanol in an ultrasonic bath. Under high-contrast back-scattered electrons (BSE) imaging, the monazite-(Ce) grains show faint zonation and patchiness in cross section, which is related to slight variations in the $\mathrm{ThO}_{2}$ content.

The xenotime-(Y) used for experiments is a part of a gem quality, euhedral crystal from a pegmatite in the North-West Frontier Province (NWFP), Pakistan. A fragment of the xenotime-(Y) crystal was crushed and sieved to obtain a 50 $250 \mu \mathrm{m}$ grain size fraction. Optically clear grains with no inclusions of foreign mineral phases were hand picked out using a binocular microscope. The xenotime-(Y) separate was then washed in ethanol in an ultrasonic bath.

Four mineral starting mixes were prepared, two for monazite- $(\mathrm{Ce})$ and two for xenotime- $(\mathrm{Y})$ in the presence of silicate minerals. The silicate starting mixes roughly replicate the composition of granitic to pelitic rocks in which the altered monazite-(Ce) and xenotime-(Y) are most commonly found. Each set of experiments have a high bulk $\mathrm{CaO}$ content with respect to natural granites and pelites, i.e. estimated 10.08 wt.\% in set (1), $5.91 \mathrm{wt} . \%$ in set (2), $9.21 \mathrm{wt} . \%$ in set (3) and $5.56 \mathrm{wt} . \%$ in set (4) (Table 2). The two silicate starting mixes were prepared for the monazite-(Ce) and xenotime-(Y) experiments (Table 1). These included (1) monazite-(Ce), labradorite $\left(\mathrm{Ab}_{37} \mathrm{An}_{60} \mathrm{Kfs}_{3}\right.$; Chihuahua, Mexico), sanidine (Eifel region, Germany), biotite (migmatitic gneiss, Sikkim Himalaya, India), muscovite (pegmatite, Siedlimowice, Sudety Mts., Poland), $\mathrm{SiO}_{2}, \mathrm{CaF}_{2}$, and $2 \mathrm{M} \mathrm{Ca}(\mathrm{OH})_{2} ;$ (2) monazite-(Ce), hydrothermal albite ( $\mathrm{Ab}_{100}$; Rožňava, Slovak Republic), sanidine, biotite, muscovite, $\mathrm{SiO}_{2}, \mathrm{CaF}_{2}$, $\mathrm{Na}_{2} \mathrm{Si}_{2} \mathrm{O}_{5}$, and doubly distilled $\mathrm{H}_{2} \mathrm{O}$; (3) xenotime-(Y), 


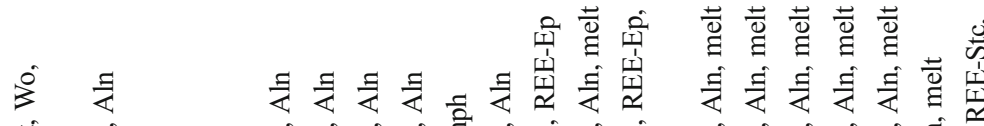

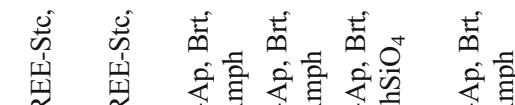
茂苗 की की

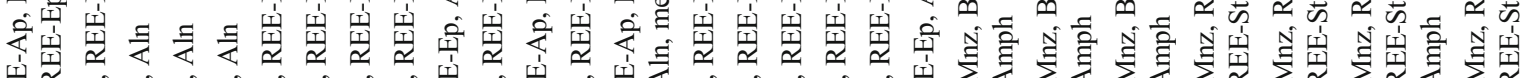

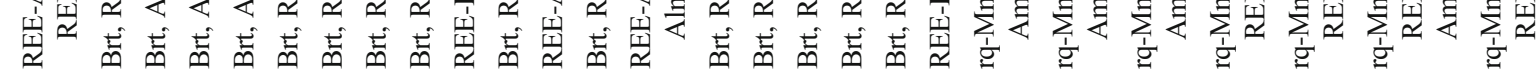

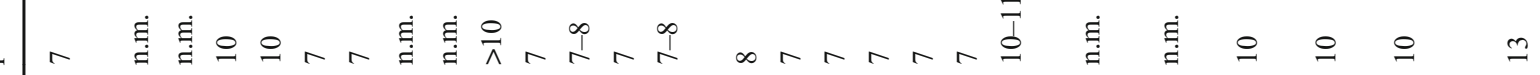

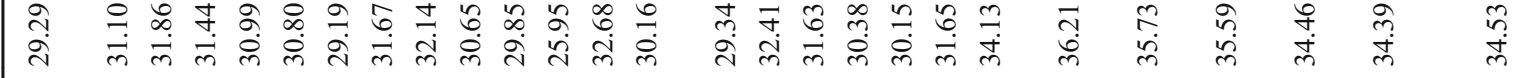

से \& \& 유

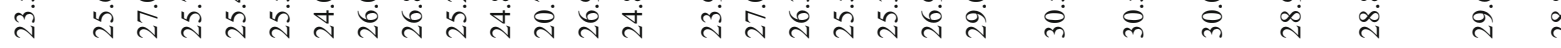

$\rightarrow$ 궁.

ले

点

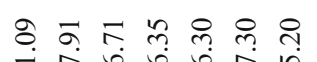

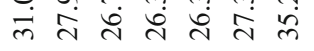

萬

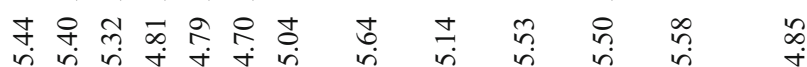

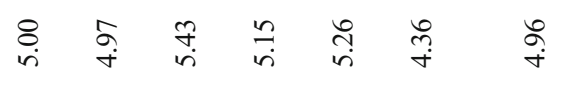

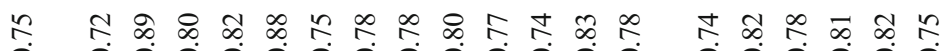

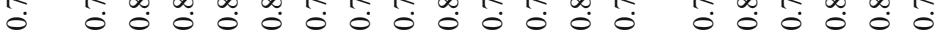

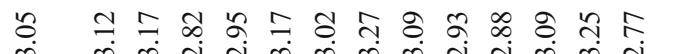

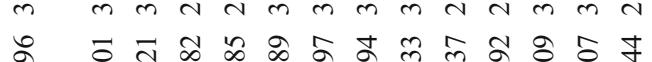

담ำ의

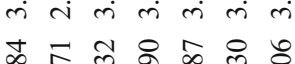

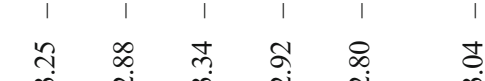

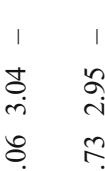

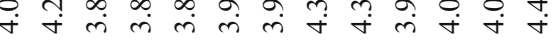

लं

+.

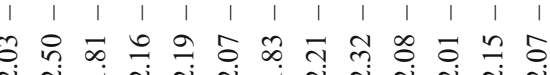

$\begin{array}{ccccccc}1 & 1 & 1 & 1 & 1 & 1 & 1 \\ 0 & \ddots & 0 & \infty & \infty & n & \infty\end{array}$

ป ^ิ

त

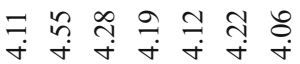

ㅇำ กิ กิ กิ ชิ

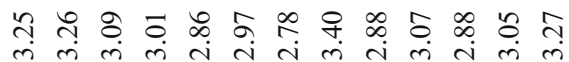

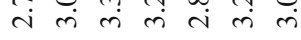

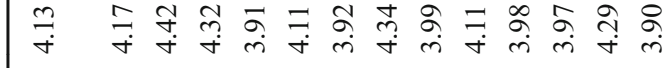

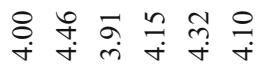

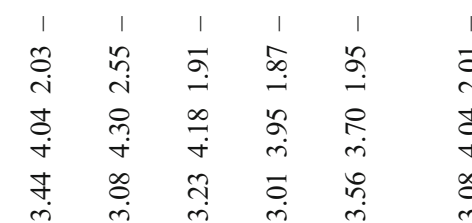

$\begin{array}{llllllll}1 & 1 & 1 & 1 & 1 & 1 & \dot{*}\end{array}$

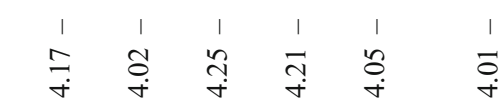

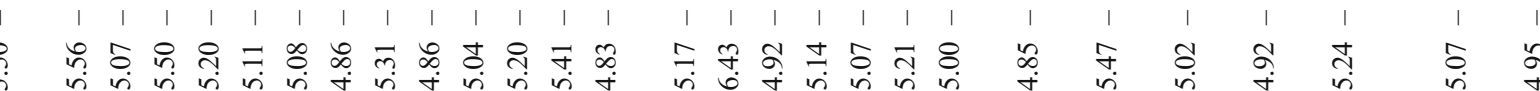
ก

$0 \infty 000 \simeq 0 \infty \pi \infty 0000$ 0 


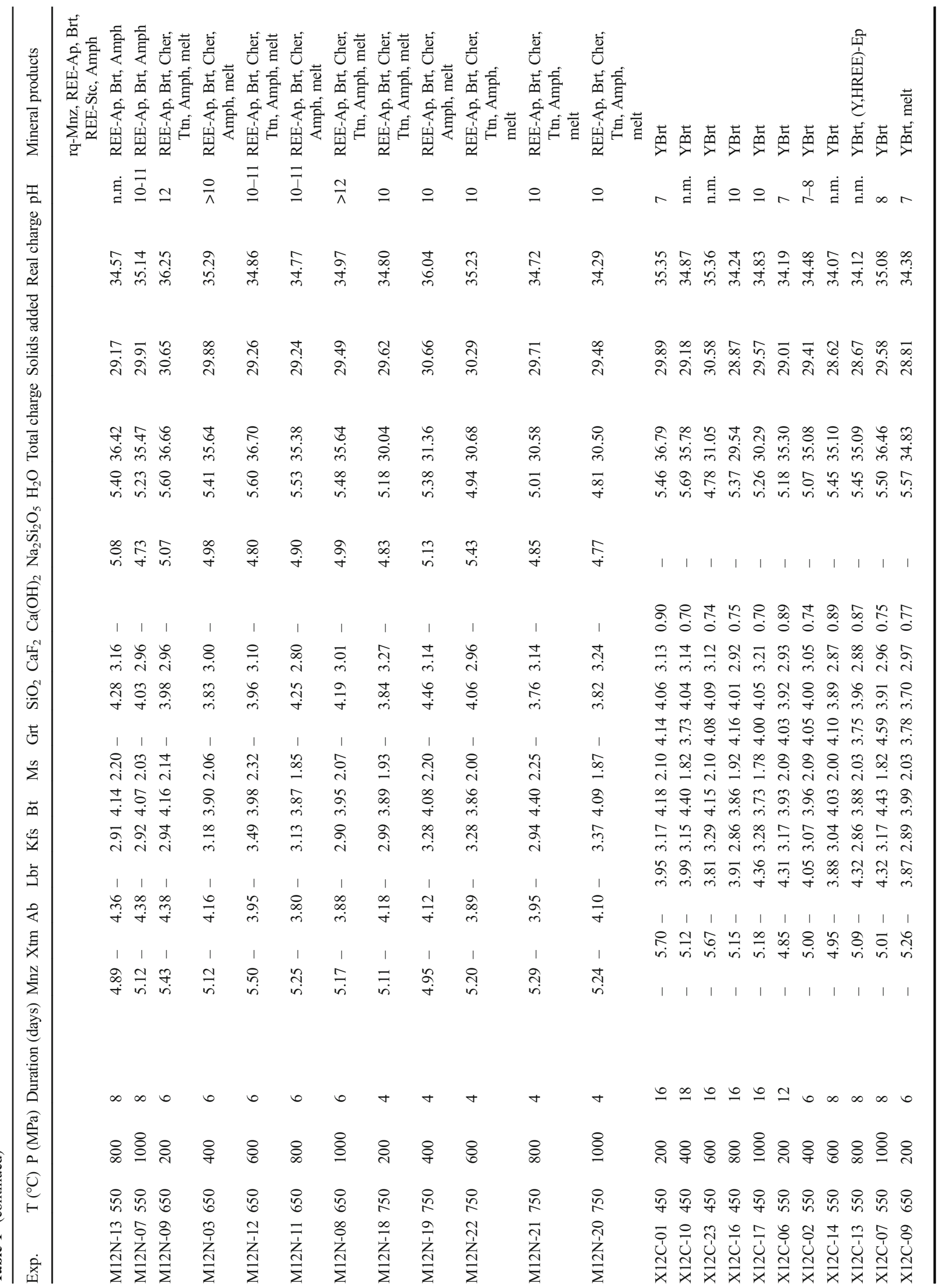




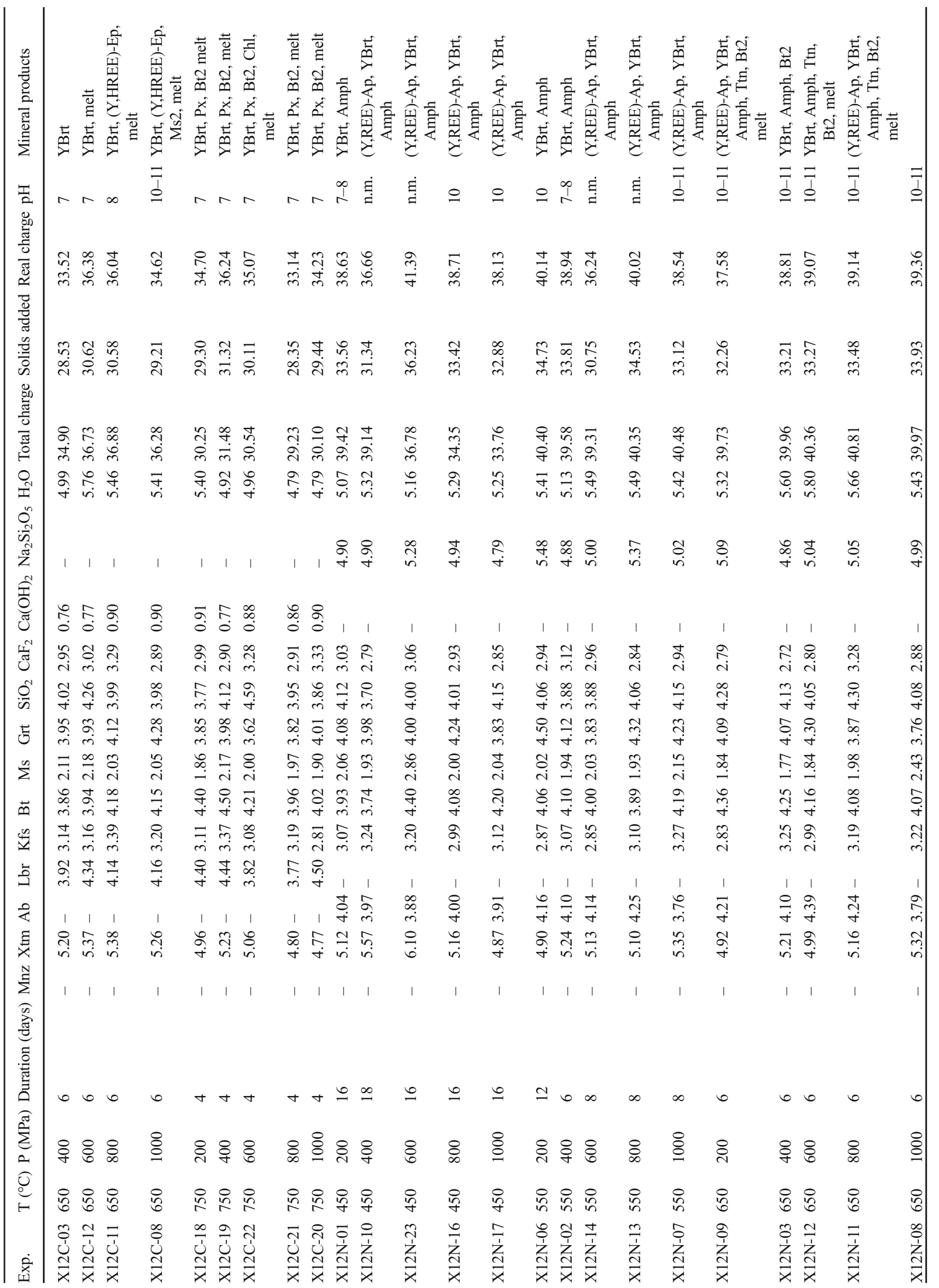




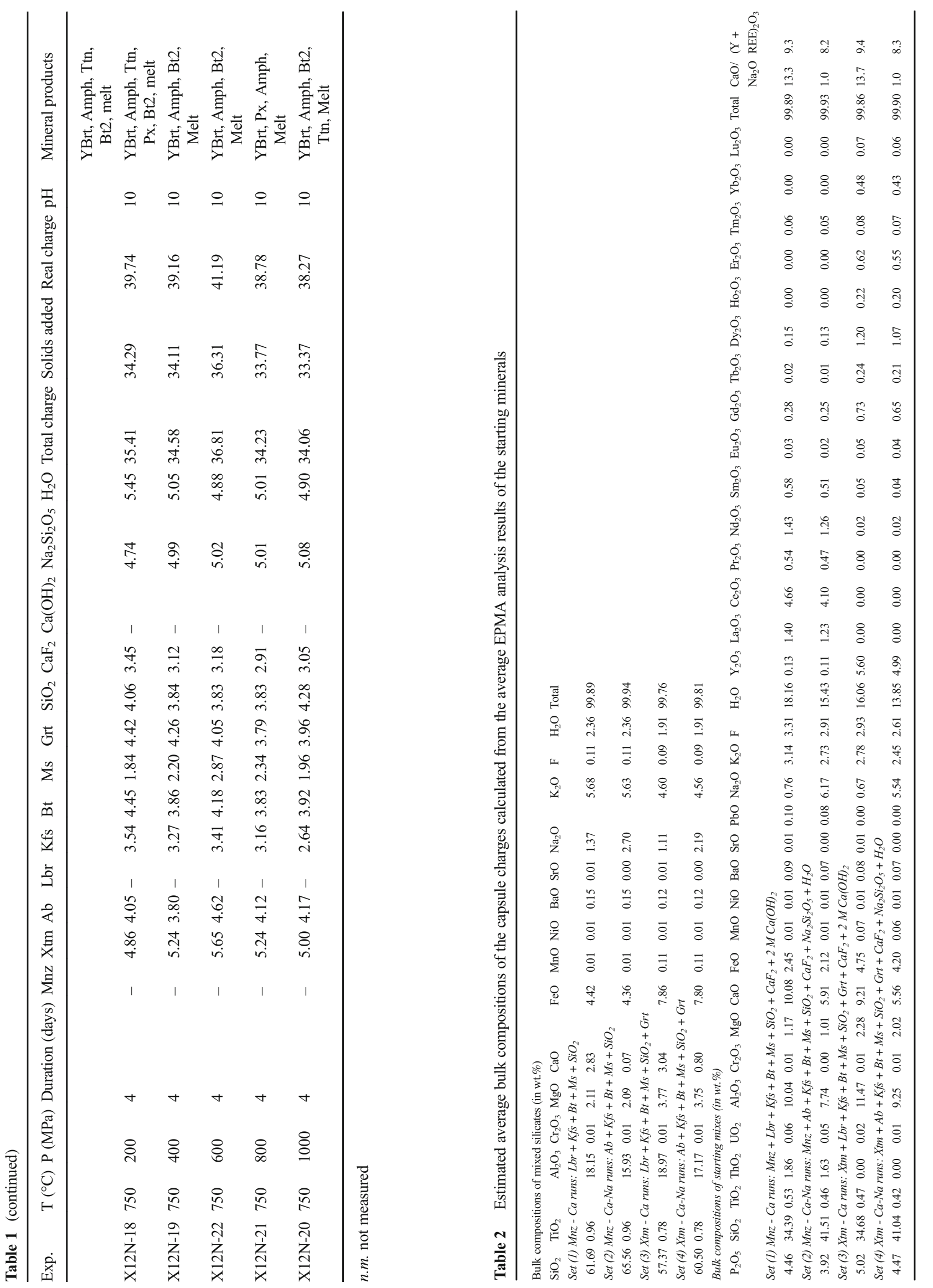


labradorite, sanidine, biotite, muscovite, garnet (Gore Mt., USA), $\mathrm{SiO}_{2}, \mathrm{CaF}_{2}$, and $2 \mathrm{M} \mathrm{Ca}(\mathrm{OH})_{2}$ fluid; and (4) xenotime-(Y), albite, sanidine, biotite, muscovite, garnet, $\mathrm{SiO}_{2}, \mathrm{CaF}_{2}, \mathrm{Na}_{2} \mathrm{Si}_{2} \mathrm{O}_{5}$, and doubly distilled $\mathrm{H}_{2} \mathrm{O}$ (Table 1). The $2 \mathrm{M} \mathrm{Ca}(\mathrm{OH})_{2}$ solution was prepared using a $\mathrm{Ca}(\mathrm{OH})_{2}$ chemical reagent (Merck) and doubly distilled $\mathrm{H}_{2} \mathrm{O}$. Synthetic amorphous $\mathrm{SiO}_{2}$ was used instead of quartz to increase the reaction rates. $\mathrm{CaF}_{2}$ (suprapur; Merck 2842) was used as a source of $\mathrm{Ca}$ and $\mathrm{F}$ to form fluorapatite. Labradorite was used in experiments with $2 \mathrm{M} \mathrm{Ca}(\mathrm{OH})_{2}$ as an additional source of $\mathrm{Ca}$, whereas albite was used in experiments with $\mathrm{Na}_{2} \mathrm{Si}_{2} \mathrm{O}_{5}+\mathrm{H}_{2} \mathrm{O}$ to increase the $\mathrm{Na}$ bulk content. Experiments with xenotime-(Y) included garnet to test $\mathrm{Y}$ partitioning between xenotime-(Y) and garnet. The estimated average bulk composition of the silicate mixes and all other components used in each capsule charge, calculated based on the average composition of each starting phase, are presented in Table 2. High amounts of monazite-(Ce) and xenotime-(Y) in the starting mixes were used in order that these phases might be easily found in the grain mounts. This, however, significantly increased the bulk REE and P contents in the experiments compared to their actual relative abundances in natural rocks.

The minerals in the silicate mixes were crushed and sieved to obtain a 50 to $250 \mu \mathrm{m}$ fraction. Foreign and cloudy mineral grains were hand picked out under the binocular microscope. The Au capsules, $15 \mathrm{~mm}$ long and $3 \mathrm{~mm}$ wide (outer diameter $3.0 \mathrm{~mm}$, inner diameter $2.6 \mathrm{~mm}$ ), were loaded with $\sim 5 \mathrm{mg}$ of doubly distilled $\mathrm{H}_{2} \mathrm{O}, 20-36 \mathrm{mg}$ of mixed solids (Table 1), and arc-welded shut using a Lampert PUK-04 precision welding device. The Au capsules were checked for leaks by weighing, heating in a $105^{\circ} \mathrm{C}$ oven overnight, and then weighed again.

Experiments at 200 to $400 \mathrm{MPa}$ and 450 to $750{ }^{\circ} \mathrm{C}$ (Table 1) were performed in standard cold-seal, $6 \mathrm{~mm}$ bore, René metal autoclaves with $\mathrm{H}_{2} \mathrm{O}$ as the pressure medium. Four gently flattened $\mathrm{Au}$ capsules, two with monazite-(Ce) [experimental sets (1) and (2)] and two with xenotime-(Y) [experimental sets (3) and (4)], were placed in each autoclave. During the run, the experiments were buffered at approximately the Ni-NiO oxygen buffer due to the presence of Ni metal filler rods, which occupied the bore of the autoclave not occupied by the Au capsules. Temperatures were measured externally by a thermocouple tip inserted into the end of autoclave near the Au capsules. Thermocouples are accurate to within $\pm 3{ }^{\circ} \mathrm{C}$. No variation in temperature was observed during each run. The maximum temperature gradient along the length of a capsule was approximately $5{ }^{\circ} \mathrm{C}$ at $750{ }^{\circ} \mathrm{C}$. The temperature gradient was measured in a sealed autoclave on a hydrothermal line at $400 \mathrm{MPa}$ by placing two thermocouples in contact with both ends of a $1 \mathrm{~cm}$ long Au capsule and placing a third thermocouple in contact with the center of the capsule. For the case of $750{ }^{\circ} \mathrm{C}$, as measured by the central thermocouple, the thermal gradient was then determined by the difference between this temperature and the two temperatures measured at either end of the capsule. Pressure on the hydrothermal line was calibrated against a pressure transducer calibrated against a Heise gauge manometer for which the quoted pressure is accurate to $\pm 5 \mathrm{MPa}$. The autoclaves were quenched after the run using compressed air, reaching temperatures of $\sim 100^{\circ} \mathrm{C}$ within $1 \mathrm{~min}$.

Experiments at 600 to $1000 \mathrm{MPa}$ and 450 to $750{ }^{\circ} \mathrm{C}$ (Table 1) were performed using the piston-cylinder apparatus (Johannes et al. 1971; Johannes 1973). An $\mathrm{NaCl}$ assembly with a graphite oven was used in the 450,500 , and $650{ }^{\circ} \mathrm{C}$ runs, and a $\mathrm{CaF}_{2}$ assembly with a graphite oven was used in the $750{ }^{\circ} \mathrm{C}$ runs. In the case of the $\mathrm{CaF}_{2}$ assembly, the actual pressure during the experimental run was corrected for friction (cf. Harlov and Milke 2002). Four gently flattened Au capsules [two for the monazite-(Ce) and two for the xenotime-(Y) experiments] were positioned vertically with the $\mathrm{Ni}-\mathrm{Cr}$ thermocouple tip placed approximately halfway up alongside of one of the capsules (Fig. 1). Biotite sheets were used to separate the capsules. Estimated maximum thermal gradients along the length of the capsule are $\pm 20^{\circ} \mathrm{C}$ and were estimated in the same manner as described above for the hydrothermal autoclave experiments. Estimated uncertainty in pressure is $\pm 50 \mathrm{MPa}$ (cf. Harlov and Milke 2002). At the start of a run, the pressure was taken up to approximately $10-15 \%$ below run conditions, and then the temperature was brought up to the desired value. Thermal expansion caused the pressure to increase to the approximate target value. The pressure was then adjusted to the desired value, and automatically maintained within a preset range during the course of the experiment.

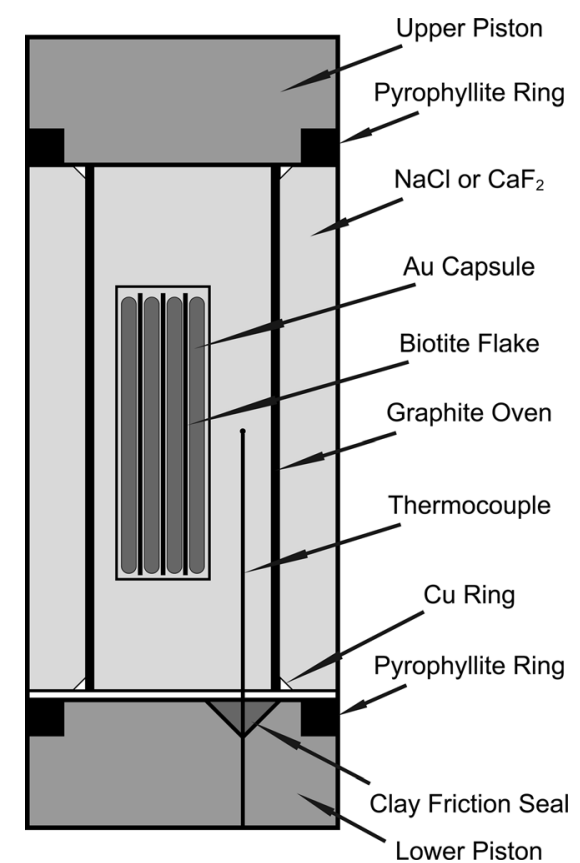

Fig. 1 Sketch of the assembly used in experiments with piston-cylinder apparatus 
During the run, the presence of the graphite oven buffered the experiment to the C-CO- $\mathrm{CO}_{2}$ oxygen buffer. Quench was achieved by turning off the current, such that $\mathrm{H}_{2} \mathrm{O}$-cooling jacket cooled down the $\mathrm{NaCl}$ or $\mathrm{CaF}_{2}$ assembly to below $50{ }^{\circ} \mathrm{C}$ within about $15 \mathrm{~s}$.

After each run, the capsules were carefully examined, cleaned, weighed, and opened. The $\mathrm{pH}$ of the fluid within the capsule was measured using litmus paper. The capsules were then dried at $105^{\circ} \mathrm{C}$ overnight. A portion of the extracted experiment was mounted in epoxy and polished for back scattered electron (BSE) imaging and electron probe micro analysis. A second part of the extracted experimental products was sprinkled on an adhesive carbon mount and carbon coated for BSE imaging. Product phase dimensions were measured in cross section in polished grain mounts. Because the exposures strongly depend dimensionally on the cross cut of the minerals during grinding down and polishing, particularly in the replacement textures, image analysis was not applied in order to avoid misleading volumetric data.

\section{Analytical methods}

The BSE imaging, and preliminary chemical analyses of the starting minerals and the experimental products were performed using a Hitachi S-4700 field emission scanning electron microscope equipped with energy dispersive spectrometer (EDS). Chemical analyses of the mixes and experimental products were performed using a JEOL JXA-8530F HyperProbe Field Emission Electron Probe Microanalyzer (EPMA) equipped with four wavelength spectrometers. Monazite-(Ce) and xenotime-(Y) analyses were collected using a $20 \mathrm{kV}$ accelerating voltage, and a $40 \mathrm{nA}$ beam current with a 3-4 $\mu \mathrm{m}$ beam size for monazite-(Ce) and $1 \mu \mathrm{m}$ beam size for xenotime-(Y). Measured concentrations of REE, U, and $\mathrm{Pb}$ were corrected (online and offline) for various interferences following the combined approach of Åmli and Griffin (1975) and Rhede (personal comm. to JM; see also Förster et al. 2012). Fluorapatite, fluorcalciobritholite, REErich steacyite, REE-rich epidote, and allanite-(Ce) were analyzed using a $20 \mathrm{kV}, 20 \mathrm{nA}$ and a $1-3 \mu \mathrm{m}$ beam size. Feldspars and micas from runs with monazite-(Ce), and amphibole from runs with monazite-(Ce) and xenotime-(Y), were analyzed using a $15 \mathrm{kV}, 10 \mathrm{nA}$, and $2 \mu \mathrm{m}$ beam size for the feldspars, a $4 \mu \mathrm{m}$ beam size for the micas, and a focused beam for the amphibole. Further details on measurement conditions can be found in supplementary Table S2.

Chemical analyses of feldspars, micas, garnets, and titanite from experiments with xenotime-(Y) [sets (3) and (4)], analyses of melt, and compositional X-ray maps of monazite-(Ce) and xenotime-(Y), were performed using a JEOL JXA-8230 SuperProbe Electron Probe Microanalyzer. Measurement conditions can be found in supplementary Table S2. Compositional WDS X-ray maps of altered monazite-(Ce) and xenotime-(Y) were collected using a $15 \mathrm{kV}$ accelerating voltage, $100 \mathrm{nA}$ beam current, $100 \mathrm{~ms}$ dwell time, $0.33 \mu \mathrm{m}$ step size, and a focused beam.

\section{Abbreviations}

The abbreviations of mineral names are used according to those proposed by Whitney and Evans (2010). Ab - albite, Aln - allanite-(Ce), Amph - amphibole, Brt fluorcalciobritholite, $\mathrm{Bt}$ - biotite, $\mathrm{Bt}_{2}$ - secondary low-Ti biotite, Btw - bytownite, Cher - cheralite, Chl - chlorite, Crn corundum, Grt - garnet, Kfs - K-feldspar, Lbr - labradorite, $\mathrm{Mnz}$ - monazite-(Ce), rq-Mnz - re-equilibrated monazite-(Ce) with patchy zoning, Ms - muscovite, $\mathrm{Ms}_{2}-$ secondary muscovite, Or - orthoclase, $\mathrm{Px}$ - pyroxene, Qz quartz, REE-Ap - REE-rich fluorapatite, REE-Ep - REE-rich epidote, Stc - REE-rich steacyite, Ttn - titanite, Wo - wollastonite, Xtm - xenotime-(Y), (Y,REE)-Ap - (Y,REE)-rich fluorapatite, YBrt - Y-rich fluorcalciobritholite, (Y,HREE)Ep - (Y,HREE)-rich epidote.

\section{Experimental results}

\section{Experiments with monazite-(Ce) and $2 \mathrm{M} \mathrm{Ca}(\mathrm{OH})_{2}$}

Monazite-(Ce) breakdown, including various degrees of dissolution on the surface and formation of new phases, were documented in all runs (Fig. 2a, Table 3). The remaining fluid had a neutral $\mathrm{pH}$ in most products, except in runs at $450{ }^{\circ} \mathrm{C}$, 800-1000 MPa; and $550{ }^{\circ} \mathrm{C}, 1000 \mathrm{MPa}$, which tended to have a moderately high $\mathrm{pH}$ (Table 1). Monazite-(Ce) grains from runs at $450-550{ }^{\circ} \mathrm{C}$ and $200-400 \mathrm{MPa}$ are altered mostly along the rims, showing partial dissolution and overgrowth by other mineral phases (Fig. 3b, $d$ and e). In the higher P-T experiments, most of the monazite-(Ce) grains were partially dissolved in the same way, with occasional almost complete replacement by REE-rich epidote-allanite-(Ce) (Fig. 31). The composition of the monazite- $(\mathrm{Ce})$ in the experimental products is the same as the original Burnet monazite-(Ce), indicating that the remaining monazite-(Ce) was not affected by compositional alteration (Fig. 4a and b; supplementary Table S1). High Th content, in both the altered and original monazite-(Ce), is related to the huttonitic and cheralitic substitutions (Fig. 5a and b).

Elongated, hexagonal prisms of REE-rich fluorapatitefluorcalciobritholite (several $\mu \mathrm{m}$ to $\sim 20 \mu \mathrm{m}$ long) formed in most of the experiments (Fig. 3b, d, e, g, h, m and o). REE-rich fluorapatite-fluorcalciobritholite formed either on the monazite-(Ce) grain surface or as aggregates of crystals texturally unrelated to monazite-(Ce). Occasionally, REE-rich fluorapatite-fluorcalciobritholite partially replaces significant parts of the monazite-(Ce) grains forming pseudomorphs 
Fig. 2 Overview of the experimental results from runs with monazite-(Ce) $(\mathbf{a}, \mathbf{b})$ and xenotime- $(\mathrm{Y})(\mathbf{c}, \mathbf{d})$
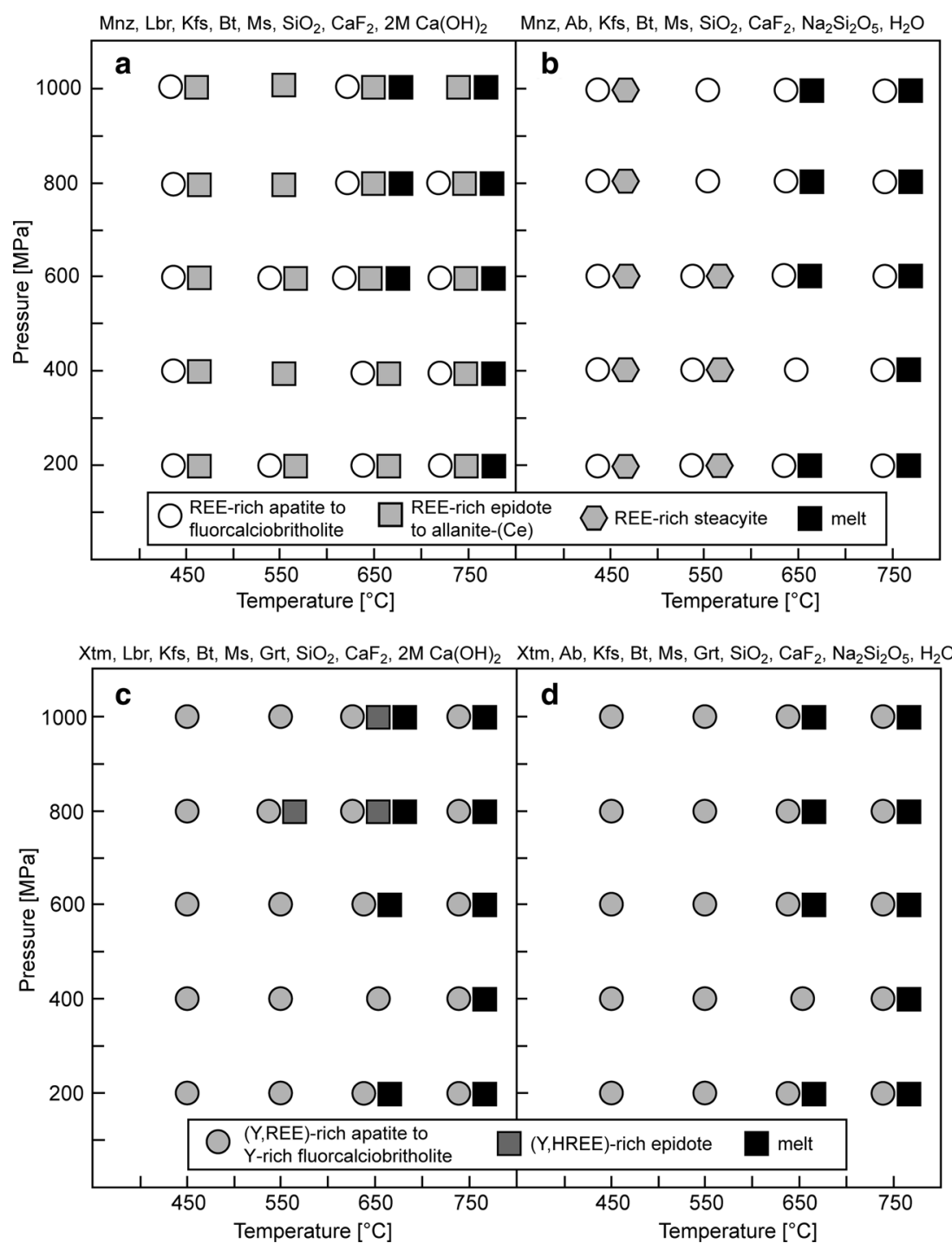

(Fig. 3j). The fluorcalciobritholite is characterized by high $\mathrm{Y}+$ REE and Th concentrations of 24.7-45.3 wt. $\%(\mathrm{Y}+\mathrm{REE})_{2} \mathrm{O}_{3}$ and 3.1-10.3 wt.\% $\mathrm{ThO}_{2}$ (supplementary Table S3). The U content is relatively low and ranges between 0.1 and $0.3 \mathrm{wt} . \%$ $\mathrm{UO}_{2}$. The fluorcalciobritholite phase represents a solid solution between fluorapatite - calciobritholite - fluorbritholite, due to coupled heterovalent substitutions on the $\mathrm{M}$ and $\mathrm{T}$ sites (cf. Pasero et al. 2010).

REE-rich epidote-allanite-(Ce) formed in all the runs. The grain size ranges from several to $\sim 50 \mu \mathrm{m}$ in low P-T runs, to large $\sim 130 \mu \mathrm{m}$ grains formed at the highest P-T conditions. From the BSE images, it is evident that the degree of monazite- $(\mathrm{Ce})$ replacement by allanite-(Ce) increases with increasing P-T conditions. It should be noted that occasionally fluorcalciobritholite is present in the near vicinity of the monazite-(Ce) grain surface, while the allanite-(Ce) crystals form outer rims around the monazite-(Ce) grains (Fig. $3 \mathrm{~m}$ ). Allanite- $(\mathrm{Ce})$ is characterized by an REE content reaching
19.7 wt. \% $\mathrm{REE}_{2} \mathrm{O}_{3}$, and a Th concentration of $1.2 \mathrm{wt} . \%$ $\mathrm{ThO}_{2}$ on average (supplementary Table S4). The Al vs. Y + REE diagram (after Petrík et al. 1995) shows that the epidotegroup minerals are compositionally solid solutions of epidote, clinozoisite, and allanite (Fig. 6). The REE-rich epidoteallanite-(Ce) from these experiments commonly demonstrate REE enrichment in the cores as relatively small areas that, when analyzed, may be contaminated with analyses from neighboring, lower REE content domains.

The starting labradorite grains preserved in all runs occasionally show compositional alterations (Table 3; supplementary Table S5). These include albite rims formed at $450{ }^{\circ} \mathrm{C}, 800 \mathrm{MPa}$, and $\mathrm{K}$-feldspar rims formed at $550{ }^{\circ} \mathrm{C}$, $200 \mathrm{MPa}$; and $650{ }^{\circ} \mathrm{C}, 200,400,1000 \mathrm{MPa}$. In runs at $750{ }^{\circ} \mathrm{C}$ and $400,800,1000 \mathrm{MPa}$, the altered labradorite grain rims achieved a composition of $\mathrm{An}_{79-94} \mathrm{Ab}_{6-17} \mathrm{Kfs}_{1-9}$ with the porosity filled by melt (Fig. 3n; supplementary Table S5). The starting K-feldspar is present in the products, except runs at 
Table 3 Overview of the products from runs with monazite-(Ce)

Set (1) monazite- $(\mathrm{Ce})+$ labradorite + sanidine + biotite + muscovite + $\mathrm{SiO}_{2}+\mathrm{CaF}_{2}+2 \mathrm{M} \mathrm{Ca}(\mathrm{OH})_{2}$

M12C-01, $450{ }^{\circ} \mathrm{C}, 200 \mathrm{MPa}, 16$ days. Monazite-(Ce) shows partial dissolution with REE-rich fluorapatite-fluorcalciobritholite grains formed on the surface. Small amounts of REE-rich epidote and wollastonite formed. Labradorite, K-feldspar and biotite are preserved. Muscovite is gone.

M12C-10, $450{ }^{\circ} \mathrm{C}, 400 \mathrm{MPa}, 18$ days. Monazite-(Ce) shows partial dissolution with small amounts of fluorcalciobritholite and REE-rich epidote-allanite-(Ce) formed on the surface. Labradorite, K-feldspar, biotite and muscovite are preserved.

$\mathrm{M12C}-23,450{ }^{\circ} \mathrm{C}, 600 \mathrm{MPa}, 16$ days. Monazite-(Ce) shows partial dissolution with numerous fluorcalciobritholite and allanite-(Ce) formed. K-feldspar, labradorite, muscovite and biotite are preserved.

M12C-16, $450{ }^{\circ} \mathrm{C}, 800 \mathrm{MPa}, 16$ days. Monazite-(Ce) shows partial dissolution with numerous fluorcalciobritholite and allanite-(Ce) formed. Some labradorite grains achieved K-feldspar rims. Kfeldspar, muscovite and biotite are preserved.

M12C-17, $450{ }^{\circ} \mathrm{C}, 1000 \mathrm{MPa}, 16$ days. Monazite-(Ce) shows partial dissolution with numerous allanite-(Ce) and fluorcalciobritholite formed. K-feldspar, labradorite, muscovite and biotite are preserved.

M12C-06, $550{ }^{\circ} \mathrm{C}, 200 \mathrm{MPa}, 12$ days. Monazite-(Ce) shows partial dissolution with small amounts of fluorcalciobritholite and REE-rich epidote-allanite-(Ce) formed. Labradorite achieved K-feldspar rims. $\mathrm{K}$-feldspar and biotite are preserved. Muscovite is gone.

M12C-02, $550{ }^{\circ} \mathrm{C}, 400 \mathrm{MPa}, 6$ days. Monazite-(Ce) shows partial dissolution with fluorcalciobritholite and REE-rich epidote-allanite(Ce) formed. Labradorite, K-feldspar, biotite and muscovite are preserved.

M12C-14, $550{ }^{\circ} \mathrm{C}, 600 \mathrm{MPa}, 8$ days. Monazite-(Ce) shows partial dissolution with fluorcalciobritholite and numerous REE-rich epidote-allanite-(Ce) formed. Labradorite, $\mathrm{K}$-feldspar and biotite are present. Muscovite is gone.

M12C-13, $550{ }^{\circ} \mathrm{C}, 800 \mathrm{MPa}, 8$ days. Monazite-(Ce) shows partial dissolution with fluorcalciobritholite and numerous REE-rich epidote-allanite-(Ce) formed. Labradorite, K-feldspar, biotite and muscovite are preserved.

M12C-07, $550{ }^{\circ} \mathrm{C}, 1000 \mathrm{MPa}, 8$ days. Monazite-(Ce) shows partial dissolution with fluorcalciobritholite and numerous REE-rich epidote-allanite-(Ce) formed. Labradorite, K-feldspar, biotite and muscovite are preserved.

M12C-09, $650{ }^{\circ} \mathrm{C}, 200 \mathrm{MPa}, 6$ days. Monazite-(Ce) shows partial dissolution with REE-rich epidote formed on the surface. Delicate crystals of fluorcalciobritholite are present on the monazite-(Ce) surface. Labradorite achieved K-feldspar rims. K-feldspar and biotite are preserved. Muscovite is gone.

M12C-03, $650{ }^{\circ} \mathrm{C}, 400 \mathrm{MPa}, 6$ days. Monazite-(Ce) shows partial dissolution with small amounts of REE-rich epidote and REEfluorapatite-fluorcalciobritholite formed. Occasionally significant parts of monazite-(Ce) grains are replaced by REE-fluorapatitefluorcalciobritholite. Labradorite achieved K-feldspar rims. Kfeldspar and biotite are preserved. Muscovite is gone

M12C-12, $650{ }^{\circ} \mathrm{C}, 600 \mathrm{MPa}, 6$ days. Monazite-(Ce) shows partial dissolution with numerous REE-rich epidote-allanite-(Ce) formed on the surface. Delicate crystals of fluorcalciobritholite formed on the monazite-(Ce) surface. Labradorite, K-feldspar and biotite are preserved. Melt formed. Muscovite is gone.

M12C-11, $650{ }^{\circ} \mathrm{C}, 800 \mathrm{MPa}, 6$ days. Monazite-(Ce) shows partial dissolution with numerous REE-rich epidote-allanite-(Ce) formed on the surface. REE-rich epidote is also dispersed in formed melt.
Table 3 (continued)

Delicate crystals of REE-rich fluorapatite-fluorcalciobritholite are present on the monazite-(Ce) surface. Some K-feldspar, labradorite and biotite preserved. Muscovite is gone.

M12C-08, $650{ }^{\circ} \mathrm{C}, 1000 \mathrm{MPa}, 6$ days. Monazite-(Ce) shows partial dissolution with REE-rich epidote-allanite-(Ce) formed. Delicate crystals of fluorcalciobritholite are present on the monazite-(Ce) surface. Melt formed. Some K-feldspar, labradorite and biotite preserved. Labradorite achieved $\mathrm{K}$-feldspar rims. Muscovite is gone.

M12C-18, $750{ }^{\circ} \mathrm{C}, 200 \mathrm{MPa}, 4$ days. Monazite-(Ce) shows partial dissolution with small grains of fluorcalciobritholite formed on the surface. Melt formed. Some REE-rich epidote-allanite-(Ce) are dispersed in melt. Feldspar with composition of bytownite forming porous grains filled with melt is present. Biotite preserved. Kfeldspar, labradorite and muscovite are gone.

M12C-19, $750{ }^{\circ} \mathrm{C}, 400 \mathrm{MPa}, 4$ days. Monazite-(Ce) shows strong dissolution with fluorcalciobritholite formed on the surface. Large REE-rich epidote-allanite-(Ce) grains are present on monazite-(Ce) surface and are dispersed in melt. Some biotite flakes are preserved. Melt formed. Feldspar with composition of bytownite forming porous grains filled with melt is present. Labradorite, $\mathrm{K}$-feldspar and muscovite are gone.

M12C-22, $750{ }^{\circ} \mathrm{C}, 600 \mathrm{MPa}, 4$ days. Monazite-(Ce) shows strong dissolution with fluorcalciobritholite and REE-rich epidote-allanite(Ce) formed on the surface. REE-epidote-allanite-(Ce) grains are present also as separate aggregates. Some K-feldspar, labradorite and biotite grains are preserved. Melt formed. Muscovite is gone.

M12C-21, $750{ }^{\circ} \mathrm{C}, 800 \mathrm{MPa}, 4$ days. Monazite-(Ce) shows strong dissolution with small grains of fluorcalciobritholite and large grains of REE-rich epidote-allanite-(Ce) formed on the surface. Melt formed. REE-rich epidote-allanite-(Ce) is also dispersed in melt. Some biotite preserved. Feldspar with composition of bytownite forming porous grains filled with melt is present. K-feldspar, labradorite and muscovite are gone.

M12C-20, $750{ }^{\circ} \mathrm{C}, 1000 \mathrm{MPa}, 4$ days. Monazite-(Ce) shows partial dissolution on the surface. Melt formed. Large grains of REE-rich epidote-allanite-(Ce) are present in melt. Some starting biotite flakes are preserved. Feldspar with composition of bytownite forming porous grains filled with melt is present. Labradorite, $\mathrm{K}$-feldspar and muscovite are gone.

Set (2) monazite- $(\mathrm{Ce})+$ albite + sanidine + biotite + muscovite $+\mathrm{SiO}_{2}+$ $\mathrm{CaF}_{2}+\mathrm{Na}_{2} \mathrm{Si}_{2} \mathrm{O}_{5}+\mathrm{H}_{2} \mathrm{O}$

M12N-01, $450{ }^{\circ} \mathrm{C}, 200 \mathrm{MPa}, 16$ days. Monazite-(Ce) shows partial dissolution with developed porosity along the rims and shows patchy zoning related to compositional alteration. Delicate

fluorcalciobritholite grains are present on the monazite-(Ce) surface. $\mathrm{K}$-feldspar achieved albite rims. Large grains of REE-rich steacyite formed. Delicate needle-like crystals of $\mathrm{Na}-(\mathrm{Fe}-\mathrm{Mg})$-amphibole are present. Albite and biotite are preserved. Muscovite is gone.

$\mathrm{M} 12 \mathrm{~N}-10,450{ }^{\circ} \mathrm{C}, 400 \mathrm{MPa}, 18$ days. Monazite-(Ce) shows strong dissolution with developed porosity along rims or across the whole grains, and displays patchy zoning. REE-rich steacyite formed grains attached to- to partially replacing monazite-(Ce) and as large individual grains. Large fluorcalciobritholite grains formed. Delicate needle-like crystals of $\mathrm{Na}-(\mathrm{Fe}-\mathrm{Mg})$-amphibole are present. Albite achieved $\mathrm{K}$-feldspar rims, and $\mathrm{K}$-feldspar achieved albite rims. Biotite and muscovite are preserved.

M12N-23, $450{ }^{\circ} \mathrm{C}, 600 \mathrm{MPa}, 16$ days. Monazite-(Ce) shows strong dissolution with developed porosity across the grains and displays patchy zoning. REE-rich steacyite formed grains attached to- to partially replacing monazite-(Ce) and as large individual grains. Large fluorcalciobritholite grains formed. Delicate needle-like 
Table 3 (continued)

crystals of $\mathrm{Na}-(\mathrm{Fe}-\mathrm{Mg})$-amphibole are present. $\mathrm{K}$-feldspar is partially replaced by albite. Albite achieved K-feldspar rims. Biotite and muscovite are preserved.

$\mathrm{M} 12 \mathrm{~N}-16,450{ }^{\circ} \mathrm{C}, 800 \mathrm{MPa}, 16$ days. Monazite-(Ce) shows patchy zoning and strong dissolution with developed porosity partially filled with REE-rich steacyite. REE-rich steacyite forms also large grains attached to monazite-(Ce). Large grains of fluorapatite to fluorcalciobritholite formed. K-feldspar achieved albite rims. Albite achieved K-feldspar rims. Delicate needle-like crystals of Na-(Fe$\mathrm{Mg}$ )-amphibole are present. Muscovite and biotite are gone.

M12N-17, $450{ }^{\circ} \mathrm{C}, 1000 \mathrm{MPa}, 16$ days. Monazite-(Ce) shows strong dissolution with developed porosity partially filled with REE-rich steacyite, and displays internal patchy zoning. REE-rich steacyite forms also large grains attached to monazite-(Ce). Large grains of fluorapatite-fluorcalciobritholite formed. K-feldspar achieved albite rims. Albite achieved K-feldspar rims. Delicate needle-like crystals of $\mathrm{Na}-(\mathrm{Fe}-\mathrm{Mg})$-amphiboles are present. Rare muscovite and biotite are present.

M12N-06, $550{ }^{\circ} \mathrm{C}, 200 \mathrm{MPa}, 12$ days. Monazite-(Ce) shows strong dissolution with porosity along the rims and displays internal patchy zoning. $\mathrm{ThSiO}_{4}$ and fluorapatite-fluorcalciobritholite inclusions formed in monazite-(Ce). Delicate fluorapatite-fluorcalciobritholite grains are also present on the monazite-(Ce) surface. REE-rich steacyite formed on the monazite-(Ce) surface and as individual grains. K-feldspar achieved albite rims. Delicate needle-like crystals of $\mathrm{Na}-(\mathrm{Fe}-\mathrm{Mg})$-amphibole are present. Aggregates of newly-formed small grains of albite are present. Muscovite and biotite are gone.

M12N-02, $550{ }^{\circ} \mathrm{C}, 400 \mathrm{MPa}, 6$ days. Monazite-(Ce) shows dissolution with fluorapatite-fluorcalciobritholite formed on the surface, and displays internal patchy zoning. Small grains of REErich steacyite formed. K-feldspar achieved albite rims. Albite achieved K-feldspar rims. Delicate needle-like crystals of Na-(Fe$\mathrm{Mg}$ )-amphibole are present. Biotite and muscovite are gone.

M12N-14, $550{ }^{\circ} \mathrm{C}, 600 \mathrm{MPa}, 8$ days. Monazite-(Ce) shows strong dissolution with fluorcalciobritholite present on the surface, and displays internal patchy zoning. Fluorcalciobritholite forms also single grains and shows sector zoning with two compositions fluorapatite-fluorcalciobritholite in the cores and fluorcalciobritholite in the rims. Delicate needle-like crystals of $\mathrm{Na}-(\mathrm{Fe}-\mathrm{Mg})$-amphibole are present. Large grains of REE-rich steacyite formed. Albite shows porosity developed along the rims or achieved K-feldspar rims. Kfeldspar achieved albite rims. Muscovite and biotite are gone.

M12N-13, $550{ }^{\circ} \mathrm{C}, 800 \mathrm{MPa}, 8$ days. Monazite-(Ce) shows strong dissolution with parallelly oriented porosity across the grains. Grains of fluorcalciobritholite grains formed on the monazite-(Ce) surface and as individual grains. Fluorcalciobritholite shows sector zoning with two compositions of fluorapatite-fluorcalciobritholite in the cores and fluorcalciobritholite in the rims. Delicate needle-like crystals of $\mathrm{Na}-(\mathrm{Fe}-\mathrm{Mg})$-amphibole are present. Albite shows porosity developed along the rims or achieved $\mathrm{K}$-feldspar rims. K-feldspar is preserved. Muscovite and biotite are gone.

M12N-07, $550{ }^{\circ} \mathrm{C}, 1000 \mathrm{MPa}, 8$ days. Monazite-(Ce) shows partial dissolution on the surface and some porosity developed. Delicate fluorapatite-fluorcalciobritholite grains formed on the monazite-(Ce) surface. Albite achieved K-feldspar rims. Delicate needle-like crystals of $\mathrm{Na}-(\mathrm{Fe}-\mathrm{Mg})$-amphibole are present. K-feldspar, muscovite and biotite are preserved.

M12N-09, $650{ }^{\circ} \mathrm{C}, 200 \mathrm{MPa}, 6$ days. Monazite-(Ce) shows strong dissolution with porosity channels across the grains filled with fluorcalciobritholite and cheralite. Fluorcalciobritholite shows sector zoning with compositions of fluorapatite-fluorcalciobritholite in the cores, and fluorcalciobritholite in the rims. Delicate needle-like
Table 3 (continued)

crystals of $\mathrm{Na}-(\mathrm{Fe}-\mathrm{Mg})$-amphibole are present. Melt and single grains of titanite formed. Some K-feldspar and albite are preserved. Albite achieved K-feldspar rims. K-feldspar is partially replaced by albite. Muscovite and biotite are gone.

M12N-03, $650{ }^{\circ} \mathrm{C}, 400 \mathrm{MPa}, 6$ days. Monazite-(Ce) shows strong dissolution with fluorcalciobritholite and cheralite formed on the surface. Fluorcalciobritholite shows sector zoning with composition of fluorapatite-fluorcalciobritholite in the cores, and

fluorcalciobritholite in the rims. Delicate needle-like crystals of Na(Fe-Mg)-amphibole are present. Melt formed. Some K-feldspar and albite are preserved. Albite achieved K-feldspar rims. Muscovite and biotite are gone.

M12N-12, $650{ }^{\circ} \mathrm{C}, 600 \mathrm{MPa}, 6$ days. Monazite-(Ce) shows strong dissolution with porosity channels along the rims filled with fluorcalciobritholite and cheralite. Fluorcalciobritholite shows sector zoning with composition of fluorapatite-fluorcalciobritholite in the cores and fluorcalciobritholite in the rims. Delicate needle-like crystals of $\mathrm{Na}-(\mathrm{Fe}-\mathrm{Mg})$-amphibole are present. Melt and single grains of titanite formed. Some starting K-feldspar and albite are preserved. Albite achieved K-feldspar rims. Muscovite and biotite are gone.

M12N-11, $650{ }^{\circ} \mathrm{C}, 800 \mathrm{MPa}, 6$ days. Monazite-(Ce) shows strong dissolution with fluorcalciobritholite and cheralite formed on the surface. Fluorcalciobritholite shows sector zoning with composition of fluorapatite-fluorcalciobritholite in the cores and fluorcalciobritholite in the rims. Delicate needle-like crystals of Na(Fe-Mg)-amphibole are present. Melt formed. Some albite and Kfeldspar are preserved. Muscovite and biotite are gone.

M12N-08, $650{ }^{\circ} \mathrm{C}, 1000 \mathrm{MPa}, 6$ days. Monazite-(Ce) shows strong dissolution with porosity channels across the grains filled with fluorcalciobritholite and cheralite. Fluorcalciobritholite shows sector zoning with composition of fluorapatite-fluorcalciobritholite in the cores and fluorcalciobritholite in the rims. Delicate needle-like crystals of $\mathrm{Na}-(\mathrm{Fe}-\mathrm{Mg})$-amphibole are present. Melt and single grains of titanite formed. Some K-feldspar and albite are preserved. Muscovite and biotite are gone.

M12N-18, $750{ }^{\circ} \mathrm{C}, 200 \mathrm{MPa}, 4$ days. Monazite-(Ce) shows strong dissolution with fluorcalciobritholite and cheralite formed on the surface. Fluorcalciobritholite shows sector zoning with composition of fluorapatite-fluorcalciobritholite in the cores and fluorcalciobritholite in the rims. Delicate needle-like crystals of Na(Fe-Mg)-amphibole are present. Titanite and melt formed. Albite, Kfeldspar, muscovite and biotite are gone.

$\mathrm{M} 12 \mathrm{~N}-19,750{ }^{\circ} \mathrm{C}, 400 \mathrm{MPa}, 4$ days. Monazite-(Ce) shows strong dissolution with fluorcalciobritholite and cheralite formed on the surface. Fluorcalciobritholite shows sector zoning with composition of fluorapatite-fluorcalciobritholite in the cores and fluorcalciobritholite in the rims. Delicate needle-like crystals of Na(Fe-Mg)-amphibole are present. Melt formed. Albite, K-feldspar, muscovite and biotite are gone.

M12N-22, $750{ }^{\circ} \mathrm{C}, 600 \mathrm{MPa}, 4$ days. Monazite-(Ce) shows strong dissolution with fluorcalciobritholite and cheralite formed on the surface. Fluorcalciobritholite shows sector zoning with composition of fluorapatite-fluorcalciobritholite in the cores and fluorcalciobritholite in the rims. Delicate needle-like crystals with composition close to ferri-taramite are present. Titanite and melt formed. Albite, K-feldspar, muscovite and biotite are gone.

M12N-21, $750{ }^{\circ} \mathrm{C}, 800 \mathrm{MPa}, 4$ days. Monazite-(Ce) shows strong dissolution with fluorcalciobritholite and cheralite formed on the surface. Fluorcalciobritholite shows sector zoning with composition of fluorapatite-fluorcalciobritholite in the cores and fluorcalciobritholite in the rims. Delicate needle-like crystals with composition close to ferri-taramite are present. 
Table 3 (continued)

Titanite and melt formed. Albite, K-feldspar, muscovite and biotite are gone.

M12N-20, $750{ }^{\circ} \mathrm{C}, 1000 \mathrm{MPa}, 4$ days. Monazite-(Ce) shows strong dissolution with fluorcalciobritholite and cheralite formed on the surface. Fluorcalciobritholite shows sector zoning with composition of fluorapatite-fluorcalciobritholite in the cores and fluorcalciobritholite in the rims. Delicate needle-like crystals with composition close to ferri-taramite are present. Titanite formed. Melt formed. Albite, K-feldspar, muscovite and biotite are gone.

$750{ }^{\circ} \mathrm{C}, 200,400$, and $1000 \mathrm{MPa}$. The K-feldspar grains are partially to completely compositionally altered in most runs, with the altered domains depleted in $\mathrm{Na}$ and Ba relative to the starting Eifel sanidine (supplementary Table S5).

Muscovite was found in run products from the $450{ }^{\circ} \mathrm{C}$, $400-1000 \mathrm{MPa}$, and the $550{ }^{\circ} \mathrm{C}, 400,800$, and $1000 \mathrm{MPa}$ experiments (supplementary Table S6). Muscovite was not observed in the products of the remaining experiments. The biotite was observed to be unaltered in all the runs (supplementary Table S6).

Melt formed in experimental runs at $650{ }^{\circ} \mathrm{C}, 600-$ $1000 \mathrm{MPa}$; and $750^{\circ} \mathrm{C}, 200-1000 \mathrm{MPa}$ (Figs. 1a and 31-p; Table 3). The melt contains $63.56-69.84$ wt. $\% \mathrm{SiO}_{2}$, and is enriched in 0.81-1.28 wt.\% F (supplementary Table S7). Concentrations of $12.91-14.99$ wt. $\% \mathrm{Al}_{2} \mathrm{O}_{3}, 2.21-4.69$ wt. \% $\mathrm{CaO}, 1.33-1.80$ wt. $\% \mathrm{~K}_{2} \mathrm{O}$, and $0.14-0.70$ wt. $\% \mathrm{Na}_{2} \mathrm{O}$ define a peraluminous composition with an alumina saturation index (ASI) of 2.4-3.5. The CIPW Qz-Ab-Or diagram (supplementary Fig. S1) shows that the melt is dominated by quartz, which places the normative composition of the melt outside that of a granite.

\section{Experiments with monazite-(Ce) and $\mathrm{Na}_{2} \mathrm{Si}_{2} \mathrm{O}_{5}+\mathrm{H}_{2} \mathrm{O}$}

All experiments with $\mathrm{Na}_{2} \mathrm{Si}_{2} \mathrm{O}_{5}+\mathrm{H}_{2} \mathrm{O}$ resulted in monazite-(Ce) breakdown (Figs. 7, 8 and 9; Table 3). At the end of each experiment, the remaining fluid in the capsule had a high $\mathrm{pH}$ (Table 1). Monazite-(Ce) in the $450{ }^{\circ} \mathrm{C}, 200$ $1000 \mathrm{MPa}$; and $550{ }^{\circ} \mathrm{C}, 200-600 \mathrm{MPa}$ experiments developed dissolution pits on the surface and porosity within altered areas of the grains (Figs. $7 \mathrm{a}$ and 8 ). Some monazite-(Ce) grains are partially replaced by REE-rich steacyite (Figs. 7c and 9). In cross section, the monazite-(Ce) shows patchy zoning with irregular boundaries between bright and dark patches under high contrast BSE imaging. The bright domains have a composition similar to the starting Burnet monazite-(Ce), while the dark domains are depleted in Th, U, and $\mathrm{Y}$ (Fig. 8b-d), with almost complete removal of $\mathrm{Pb}$ (Fig. $4 \mathrm{c}$ and d), and subsequent enrichment in REE, particularly LREE (supplementary Table S1).

Monazite-(Ce), from the runs at P-T conditions of $550{ }^{\circ} \mathrm{C}, 800$ and $1000 \mathrm{MPa}$, and $650-750{ }^{\circ} \mathrm{C}, 200$
$1000 \mathrm{MPa}$, was strongly reacted, showing large dissolution pits on the surface (Fig. $7 \mathrm{f}$ and $\mathrm{h}$ ), and an oriented porosity across the grains, filled with other minerals. The monazite-(Ce) is overgrown by REE-rich fluorapatitefluorcalciobritholite (Fig. 7g, h, n and o; supplementary Table S3). Occasionally, most of the monazite-(Ce) is replaced by REE-rich fluorapatite-fluorcalciobritholite formed in pores oriented parallel to each other along grain rims (Fig. $7 \mathrm{~g}$ ) or across whole grains (Fig. $7 \mathrm{k}$ and 1). Minute, euhedral to elongated, anhedral grains of cheralite are also present as inclusions at the boundary between the REE-rich fluorapatite-fluorcalciobritholite and host monazite-(Ce) (Fig. 7l).

REE-rich fluorapatite-fluorcalciobritholite formed in all the experiments. Beside partially replacing and/or overgrowing monazite-(Ce), the REE-rich fluorapatitefluorcalciobritholite also formed individual grains or grain aggregates. These individual grains are elongated hexagonal crystals, which range in size from several microns (lowest P-T runs), up to $100 \mu \mathrm{m}$ long and $\sim 8 \mu \mathrm{m}$ across (in the moderate to highest P-T runs). Some grains are sector zoned with a fluorcalciobritholite composition in the center, and a REE-rich fluorapatite in triangular sectors expanding from the center of the grain towards the rim (Fig. $7 \mathrm{~m}$ ). The sector zoning is related to trace element incorporation as controlled by the crystal surface structure during growth of the apatite crystals, and subsequent enrichment of selected sectors in REE (Rakovan and Reeder 1996; Rakovan 2002). The crystals in cross section commonly have cores with a REE-rich fluorapatite-fluorcalciobritholite composition, and a fluorcalciobritholite rim (Fig. 7n).

REE-rich steacyite is present only in products from runs at $450{ }^{\circ} \mathrm{C}, 200-1000 \mathrm{MPa}$; and $550{ }^{\circ} \mathrm{C}, 200$ $600 \mathrm{MPa}$. It forms subhedral to euhedral tetragonal grains varying in size from $10 \mu \mathrm{m}$ in the lower P-T runs up to $\sim 100 \mu \mathrm{m}$ in the $550{ }^{\circ} \mathrm{C}, 600 \mathrm{MPa}$ run (Fig. 7a, d and e). REE-rich steacyite also partially replaces altered monazite-(Ce), irregularly filling the inner regions or, occasionally, filling roughly oriented, parallel channels (Figs. 7c and $\mathrm{d}$ and 9). The composition of REE-rich steacyite is variable, ranging from 10.24 to 27.06 wt. $\% \mathrm{ThO}_{2}, 0.72-2.14$ wt. $\% \mathrm{UO}_{2}$, and $1.93-$ 9.64 wt.\% (Y + REE) ${ }_{2} \mathrm{O}_{3}$ (supplementary Table S8).

Starting albite and K-feldspar are present in products of all runs at $450-650{ }^{\circ} \mathrm{C}$ and $200-1000 \mathrm{MPa}$, whereas none was preserved in the $750{ }^{\circ} \mathrm{C}$ experiments (Table 3). Secondary albite rims formed on K-feldspar grains in runs at $450{ }^{\circ} \mathrm{C}, 200-1000 \mathrm{MPa} ; 550{ }^{\circ} \mathrm{C}, 200$ $600 \mathrm{MPa}$; and $650{ }^{\circ} \mathrm{C}, 200 \mathrm{MPa}$ (Fig. 7b; supplementary Table S5). Albite developed on K-feldspar rims in runs at $450-550{ }^{\circ} \mathrm{C}, 200-1000 \mathrm{MPa}$; and $650{ }^{\circ} \mathrm{C}, 200$ and $600 \mathrm{MPa}$ (Fig. 7j; supplementary Table S5). 

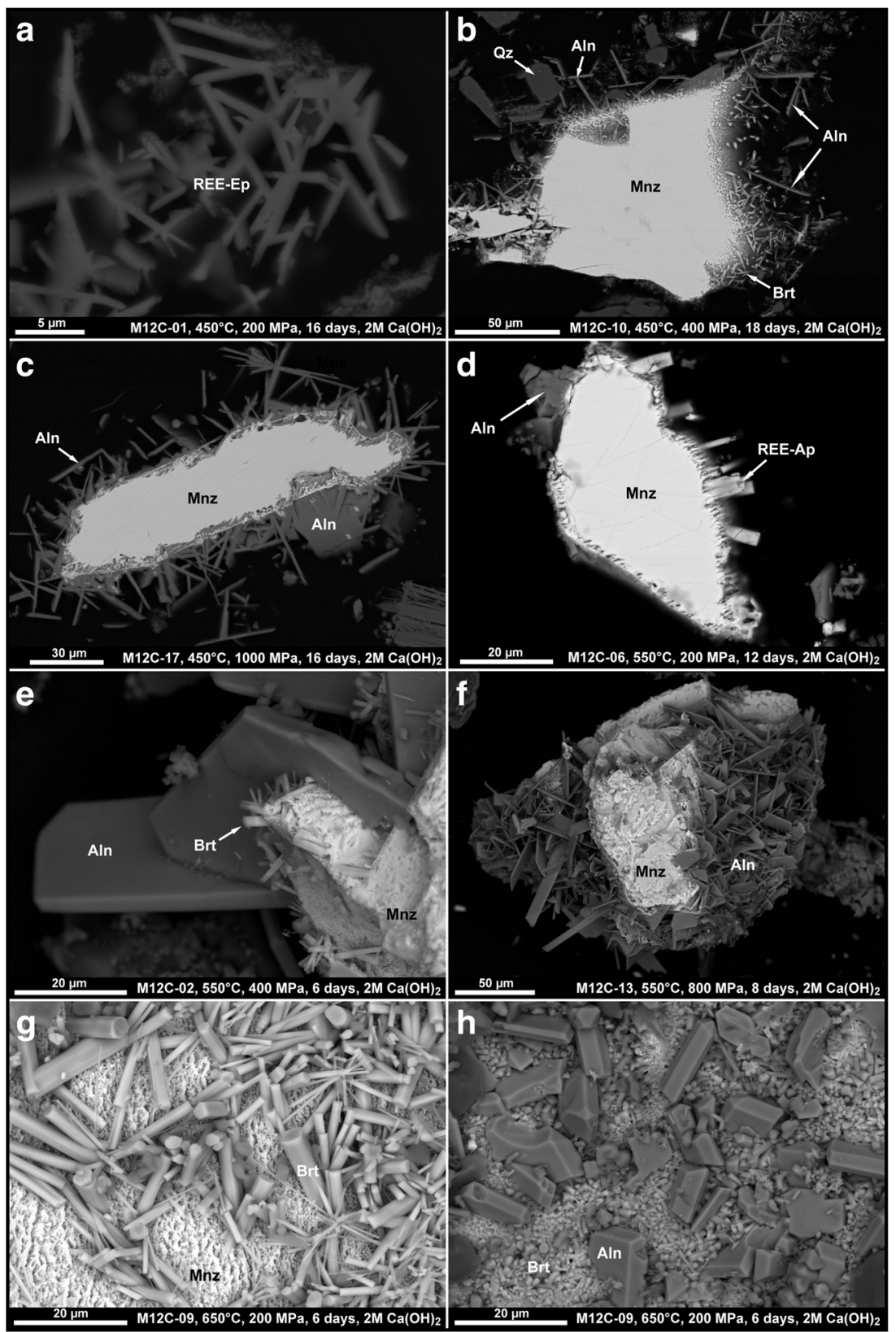

Fig. 3 BSE images showing the results from experiments with monazite(Ce) and $2 \mathrm{M} \mathrm{Ca}(\mathrm{OH})_{2}$; a small crystals of REE-rich epidote formed in the run at $450{ }^{\circ} \mathrm{C}, 200 \mathrm{MPa}$, and 16 days; $\mathbf{b}$ altered monazite-(Ce) overgrown by secondary fluorcalciobritholite and allanite-(Ce) at $450{ }^{\circ} \mathrm{C}$, $400 \mathrm{MPa}$, and 18 days; $\mathbf{c}$ allanite-(Ce) overgrowing altered monazite(Ce) from the run at $450{ }^{\circ} \mathrm{C}, 1000 \mathrm{MPa}$ and 16 days; d-e REE-rich fluorapatite-fluorcalciobritholite and allanite- $(\mathrm{Ce})$ overgrowing altered monazite-(Ce) in experiments at $550{ }^{\circ} \mathrm{C}, 200 \mathrm{MPa}$, and 12 days (d) and $550{ }^{\circ} \mathrm{C}, 400 \mathrm{MPa}$, and 6 days (e); f altered monazite-(Ce) overgrown by numerous tabular crystals of allanite-(Ce) at $550{ }^{\circ} \mathrm{C}, 800 \mathrm{MPa}$, and 8 days; $\mathbf{g}$ hexagonal prisms of fluorcalciobritholite formed on the altered monazite-(Ce) surface $\left(650^{\circ} \mathrm{C}, 200 \mathrm{MPa}, 6\right.$ days); $\mathbf{h}$ tabular crystals of allanite$(\mathrm{Ce})$ and minute hexagonal prisms of fluorcalciobritholite on the altered surface of the monazite-(Ce) $\left(650^{\circ} \mathrm{C}, 200 \mathrm{MPa}, 6\right.$ days $)$; i labradorite

Starting biotite and muscovite are found only in products from runs at $450^{\circ} \mathrm{C}, 400,600$, and $1000 \mathrm{MPa}$; and $550^{\circ} \mathrm{C}, 1000 \mathrm{MPa}$. with developed $\mathrm{K}$-feldspar rim $\left(650^{\circ} \mathrm{C}, 200 \mathrm{MPa}, 6\right.$ days $)$; j monazite(Ce) partially replaced by an aggregate of REE-rich fluorapatite and fluorcalciobritholite $\left(650^{\circ} \mathrm{C}, 400 \mathrm{MPa}, 6\right.$ days $)$; $\mathbf{k}$ altered monazite(Ce) grains overgrown by large crystals of allanite-(Ce) $\left(650{ }^{\circ} \mathrm{C}\right.$, $600 \mathrm{MPa}, 6$ days); 1 remnants of altered monazite-(Ce) replaced by allanite- $(\mathrm{Ce})\left(650{ }^{\circ} \mathrm{C}, 800 \mathrm{MPa}, 6\right.$ days $) ; \mathbf{m}$ overgrowths of fluorcalciobritholite, allanite-(Ce), and REE-rich epidote grains on altered monazite-(Ce), showing a decreasing distribution of REE in the products as a function of the distance from the monazite-(Ce) going outwards $\left(650{ }^{\circ} \mathrm{C}, 1000 \mathrm{MPa}, 6\right.$ days); $\mathbf{n}$ bytownite formed at the expense of labradorite, showing a melt-filled porosity $\left(750{ }^{\circ} \mathrm{C}, 400 \mathrm{MPa}, 4\right.$ days); o monazite- $(\mathrm{Ce})$ grains overgrown by fluorcalciobritholite and allanite(Ce) $\left(750^{\circ} \mathrm{C}, 600 \mathrm{MPa}, 4\right.$ days); $\mathbf{p}$ large crystals of allanite-(Ce) formed at the expense of monazite- $(\mathrm{Ce})\left(750^{\circ} \mathrm{C}, 1000 \mathrm{MPa}, 4\right.$ days $)$

The composition of the micas remained unaltered with respect to the starting composition (supplementary Table S6). 

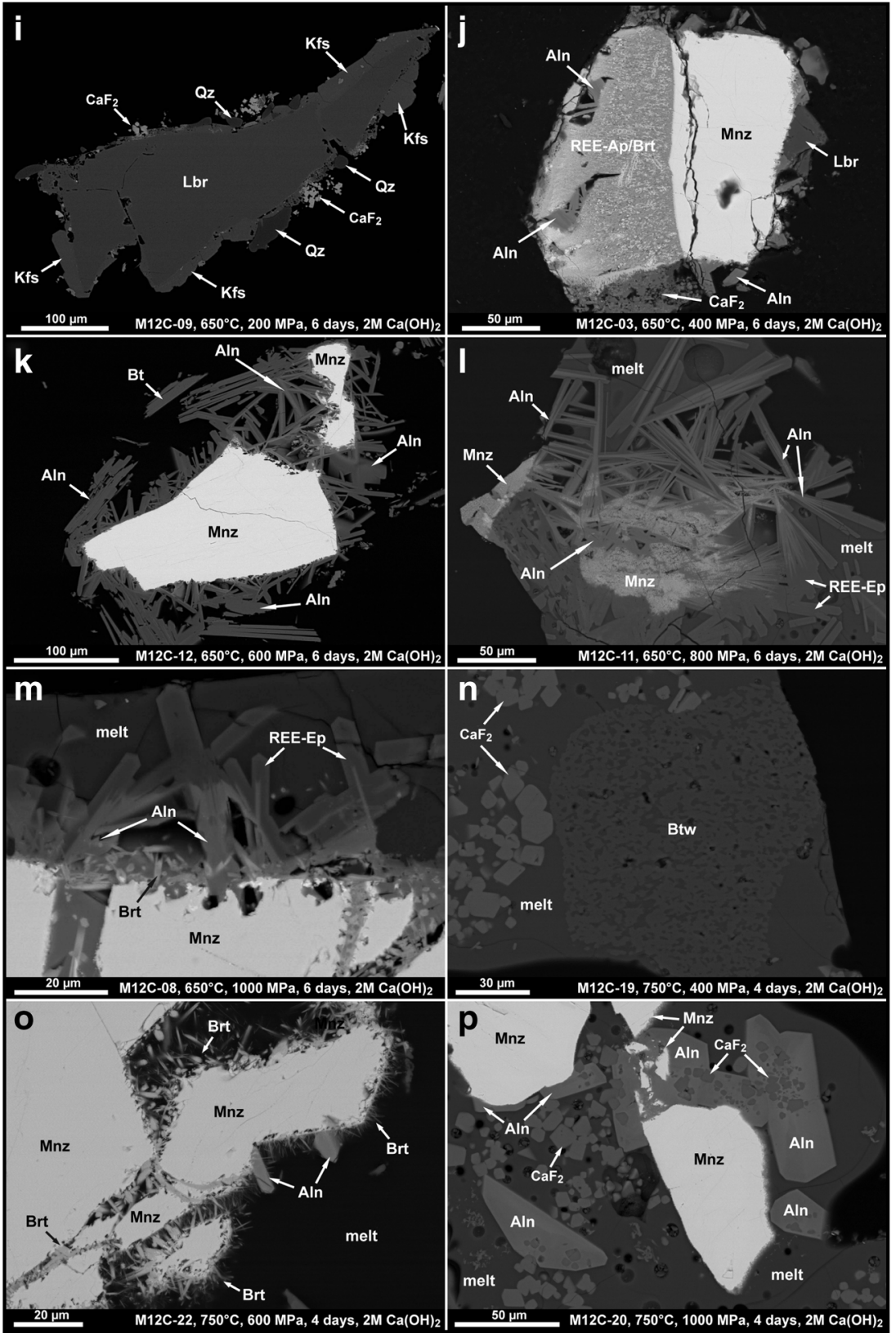

Fig. 3 (continued)

Amphibole formed in all runs with $\mathrm{Na}_{2} \mathrm{Si}_{2} \mathrm{O}_{5}+\mathrm{H}_{2} \mathrm{O}$. In experiments at 450,550 , and $650{ }^{\circ} \mathrm{C}$, needle-like crystals of amphibole were too small for EPMA measurements (Fig. 7a, $\mathrm{b}, \mathrm{d}-\mathrm{g}, \mathrm{j}$ and $\mathrm{k}$ ). SEM-EDS analyses indicate that these are $\mathrm{Na}-(\mathrm{Fe}-\mathrm{Mg})$ amphiboles, suggesting that $\mathrm{Na}_{2} \mathrm{Si}_{2} \mathrm{O}_{5}+\mathrm{H}_{2} \mathrm{O}$ and the micas were the main sources of elements for the amphibole. The highest P-T runs, at $750{ }^{\circ} \mathrm{C}, 600-1000 \mathrm{MPa}$, promoted the formation of amphibole crystals up to $20 \mu \mathrm{m}$ long and several microns across with a composition similar to ferritaramite (Leake et al. 1997; Fig. 7o; supplementary Table S9).

Melt formed in runs at $650{ }^{\circ} \mathrm{C}, 200$ and $600-1000 \mathrm{MPa}$ (Fig. $7 \mathrm{~g}-\mathrm{i}, \mathrm{k}$ and $\mathrm{m}$ ), and $750{ }^{\circ} \mathrm{C}, 200-1000 \mathrm{MPa}$ (Fig. $7 \mathrm{o}$ and p). It dominates the experimental products from runs at $750{ }^{\circ} \mathrm{C}$, in which the feldspars have totally disappeared. The melt contains $66.17-70.56 \mathrm{wt} . \% \mathrm{SiO}_{2}$ and is characterized by a peraluminous composition (ASI $=3.1-5.9$ ) defined by 13.40-15.65 wt.\% $\mathrm{Al}_{2} \mathrm{O}_{3}, 0.18-0.59$ wt.\% $\mathrm{CaO}, 0.88$ 2.18 wt. $\% \mathrm{Na}_{2} \mathrm{O}$, and 1.16-2.16 wt. $\% \mathrm{~K}_{2} \mathrm{O}$ (supplementary Table S7). The F content is $0.71-1.61$ wt.\%. The Qz-Ab-Or diagram (supplementary Fig. S1) demonstrates that the nongranitic melt is dominated by normative quartz with small amounts of normative albite and orthoclase.

Titanite also formed in most runs with melt (Table 3). Their small size did not allow for accurate EPMA measurements. 


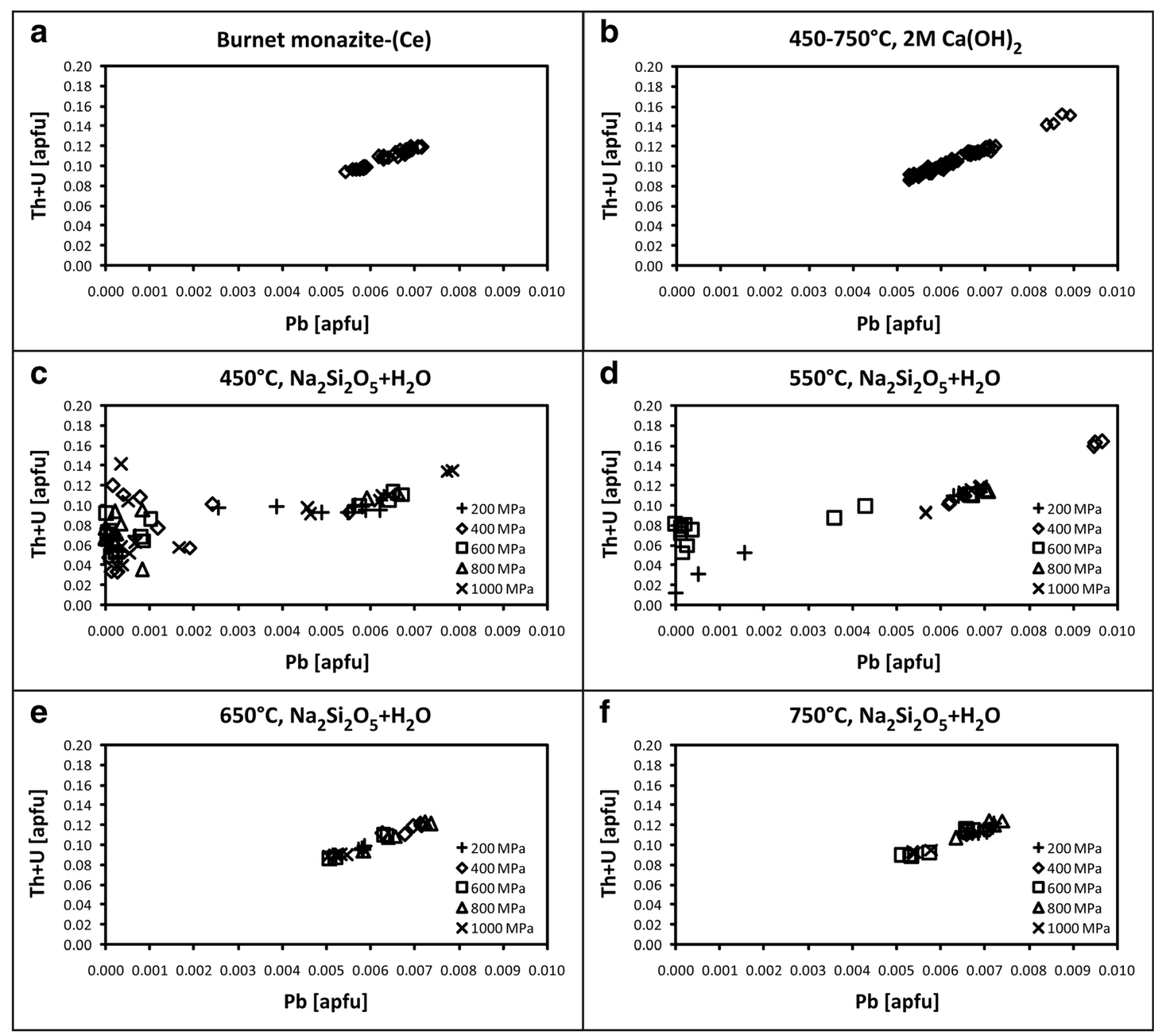

Fig. 4 Plots of $\mathrm{Pb}$ versus $\mathrm{Th}+\mathrm{U}$ contents in atoms per formula unit (apfu) showing similar patterns in the Burnet monazite-(Ce) (a), and monazite-(Ce) in products from all runs with $2 \mathrm{M} \mathrm{Ca}(\mathrm{OH})_{2}(\mathbf{b}) ; \mathbf{c}, \mathbf{d}$ the monazite-(Ce) from runs with $\mathrm{Na}_{2} \mathrm{Si}_{2} \mathrm{O}_{5}+\mathrm{H}_{2} \mathrm{O}$ at $450{ }^{\circ} \mathrm{C}$ and $550{ }^{\circ} \mathrm{C}$ shows significant depletion in $\mathrm{Pb}$, as well as in $\mathrm{Th}$ and $\mathrm{U}$, related to

compositional alterations in the monazite-(Ce) via fluid-mediated coupled dissolution-reprecipitation; $\mathbf{e}, \mathbf{f}$ the monazite-(Ce) from runs with $\mathrm{Na}_{2} \mathrm{Si}_{2} \mathrm{O}_{5}+\mathrm{H}_{2} \mathrm{O}$ under temperature conditions of $650{ }^{\circ} \mathrm{C}$ and $750{ }^{\circ} \mathrm{C}$ presents similar patterns as the original Burnet monazite-(Ce)

\section{Experiments with xenotime-( $(\mathrm{Y})$ and $2 \mathrm{M} \mathrm{Ca}(\mathrm{OH})_{2}$}

Xenotime-(Y) reacted in all runs with $2 \mathrm{M} \mathrm{Ca}(\mathrm{OH})_{2}$ (Table 4; Figs. 2c and 10). The remaining fluid in the capsule had a pH of 7 except in runs at $450{ }^{\circ} \mathrm{C}, 800-$ $1000 \mathrm{MPa}$; and $650{ }^{\circ} \mathrm{C}, 1000 \mathrm{MPa}$, where the $\mathrm{pH}$ was high (Table 1). Xenotime-(Y) grains from the $450{ }^{\circ} \mathrm{C}, 200 \mathrm{MPa}$ run show dissolution pits. A few, delicate, micron-sized crystals of Y-rich fluorcalciobritholite formed on the surface (Fig. 10a and b). Unreacted xenotime-(Y) surfaces are relatively common. In all other runs, the xenotime-(Y) is moderately to strongly reacted, with etching on the surface and overgrowth by numerous crystals of Y-rich fluorcalciobritholite (Fig. 10f and g). Strong dissolution occasionally resulted in the replacement of most of the xenotime-(Y) grain along grain fractures, by aggregates

of secondary, Y-rich fluorcalciobritholite with only a few remnants of xenotime-(Y) remaining (Fig. 10d). Although experiments at $450{ }^{\circ} \mathrm{C}$ and $200 \mathrm{MPa}$ resulted in the lowest degree of alteration, a few xenotime-(Y) grains occasionally remained unreacted even at $750{ }^{\circ} \mathrm{C}$ (Fig. 10p). Remnant xenotime-(Y) after the experiment showed no compositional alterations and preserved the composition of the original NWFP xenotime-(Y) (supplementary Table S10).

Yttrium-rich fluorcalciobritholite formed on the xenotime- $(\mathrm{Y})$ grain surface in all the runs and commonly grew along fractures in the xenotime- $(\mathrm{Y})$ grains. The elongated crystals of Y-rich fluorcalciobritholite, up to $20 \mu \mathrm{m}$ long and a few microns thick, show zoning with (Y,REE)-rich fluorapatite cores and Y-rich fluorcalciobritholite rims (Fig. $10 \mathrm{~g}$ ). Due to the small size of the Y-rich 


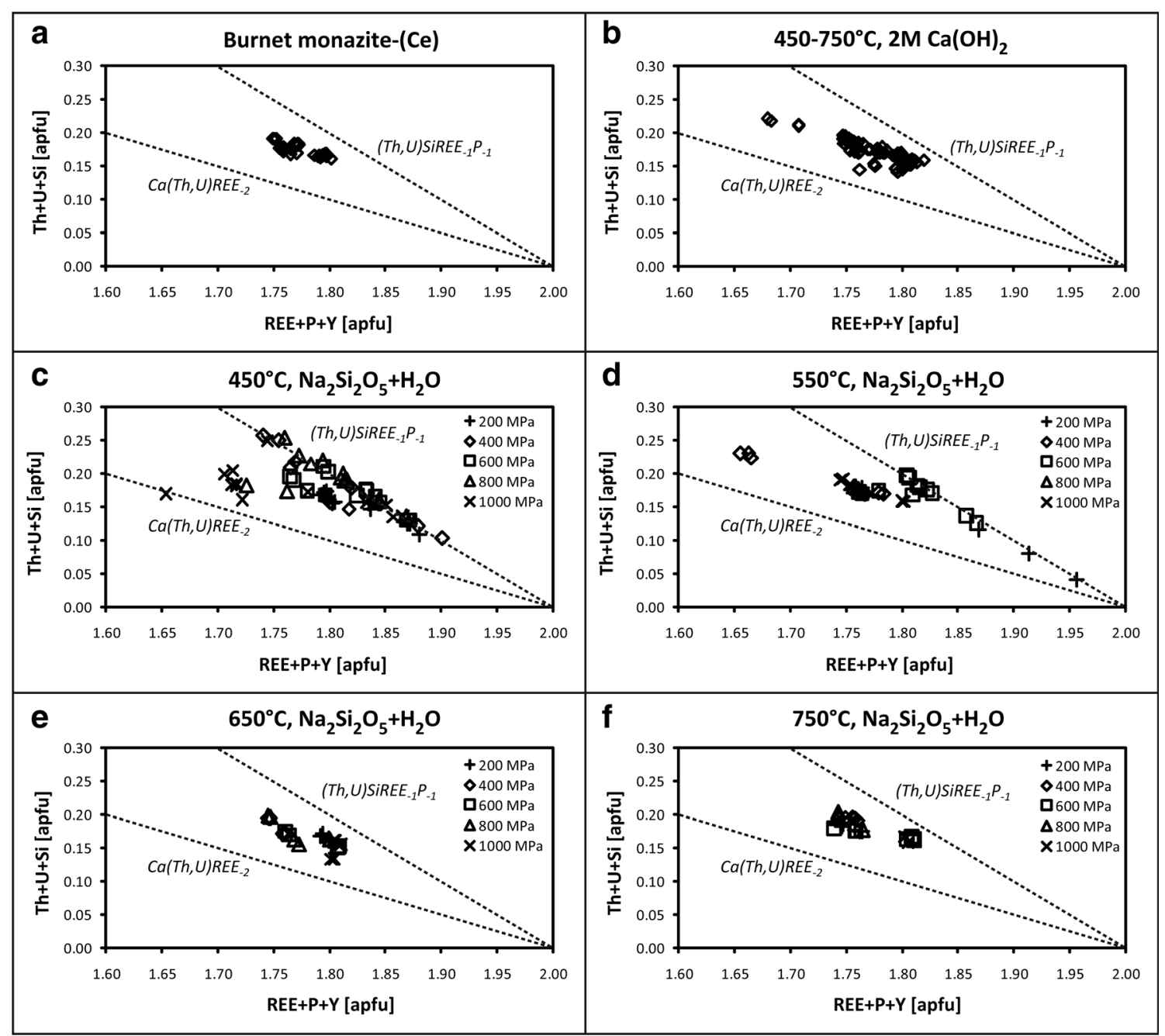

Fig. 5 Plots of formula proportions of $(\mathrm{REE}+\mathrm{Y}+\mathrm{P})$ vs. $(\mathrm{Th}+\mathrm{U}+\mathrm{Si})$ in the starting Burnet monazite-(Ce) and the monazite- $(\mathrm{Ce})$ from experimental products; dashed lines represent the huttonitic substitution (Th,U)SiREE ${ }_{-1} \mathrm{P}_{-1}$ and cheralitic substitution $\mathrm{Ca}(\mathrm{Th}, \mathrm{U}) \mathrm{REE}-2$ (Förster 1998; Linthout 2007)

fluorcalciobritholite crystals, EPMA measurements provide a mixed composition consisting of the cores and the rims (supplementary Table S11).

(Y,HREE)-rich epidote formed in three runs with $2 \mathrm{M}$ $\mathrm{Ca}(\mathrm{OH})_{2}$, i.e. at $550{ }^{\circ} \mathrm{C}, 800 \mathrm{MPa} ; 650{ }^{\circ} \mathrm{C}, 800 \mathrm{MPa}$; and $650{ }^{\circ} \mathrm{C}, 1000 \mathrm{MPa}$. The (Y,HREE)-rich epidote forms elongated crystals, up to $\sim 120 \mu \mathrm{m}$ long and $20 \mu \mathrm{m}$ thick, and is present as individual grains or grain aggregates not associated with xenotime-(Y) (Fig. 10h, k and l). The average $\mathrm{Y}$ and total REE contents in the (Y,HREE)-rich epidote are $4.06 \mathrm{wt} . \%$ $\mathrm{Y}_{2} \mathrm{O}_{3}$ and 1.71 wt. $\% \mathrm{REE}_{2} \mathrm{O}_{3}$ in the $650{ }^{\circ} \mathrm{C}, 1000 \mathrm{MPa}$ run; and 1.77 wt. $\% \mathrm{Y}_{2} \mathrm{O}_{3}$ and 0.54 wt. $\% \mathrm{REE}_{2} \mathrm{O}_{3}$ in the $650{ }^{\circ} \mathrm{C}$, $800 \mathrm{MPa}$ run (supplementary Table S12). According to the $\mathrm{Al}$ versus $\mathrm{Y}+$ REE plot in Fig. 11, the (Y,HREE)-rich epidote represents a solid solution between allanite, epidote, and clinozoisite.

Labradorite is present in the products of all runs at 450 , $550,650{ }^{\circ} \mathrm{C}$; and in the products of the $750{ }^{\circ} \mathrm{C}, 200$, $600 \mathrm{MPa}$ runs. Labradorite was rimmed by albite in two runs at $550{ }^{\circ} \mathrm{C}, 800$ and $1000 \mathrm{MPa}$ (supplementary Table S13). Secondary K-feldspar rims formed at $550{ }^{\circ} \mathrm{C}, 200$ and $400 \mathrm{MPa}$; and $550{ }^{\circ} \mathrm{C}, 200$ and $1000 \mathrm{MPa}$. The starting labradorite was not found in the experimental products at $750{ }^{\circ} \mathrm{C}$, 400,800 , and $1000 \mathrm{MPa}$, where the feldspar has a bytownite composition and melt-filled porosity. Remnants of the starting $\mathrm{K}$-feldspar were preserved in all the runs at 450,550 , and $650{ }^{\circ} \mathrm{C}$. K-feldspar was not found in the experimental products from the $750{ }^{\circ} \mathrm{C}$ runs.

Biotite is present in products from all runs at 450,550 , and $650{ }^{\circ} \mathrm{C}$. In runs at $750{ }^{\circ} \mathrm{C}$, secondary biotite formed (Fig. 10p), which is characterized by low Ti concentrations $\left(0.09-0.45\right.$ wt. $\left.\% \mathrm{TiO}_{2}\right)$ compared to the 4.09 wt. $\%$ $\mathrm{TiO}_{2}$ content in the starting biotite (supplementary Table S14). Muscovite is preserved in all runs at $450{ }^{\circ} \mathrm{C}$, three runs at $550{ }^{\circ} \mathrm{C}, 600-1000 \mathrm{MPa}$, and two runs at $650{ }^{\circ} \mathrm{C}, 600$ and $800 \mathrm{MPa}$. Small, 10-50 $\mu \mathrm{m}$ flakes of secondary muscovite formed at $650{ }^{\circ} \mathrm{C}$, $1000 \mathrm{MPa}$. In the remaining experimental products, i.e. 


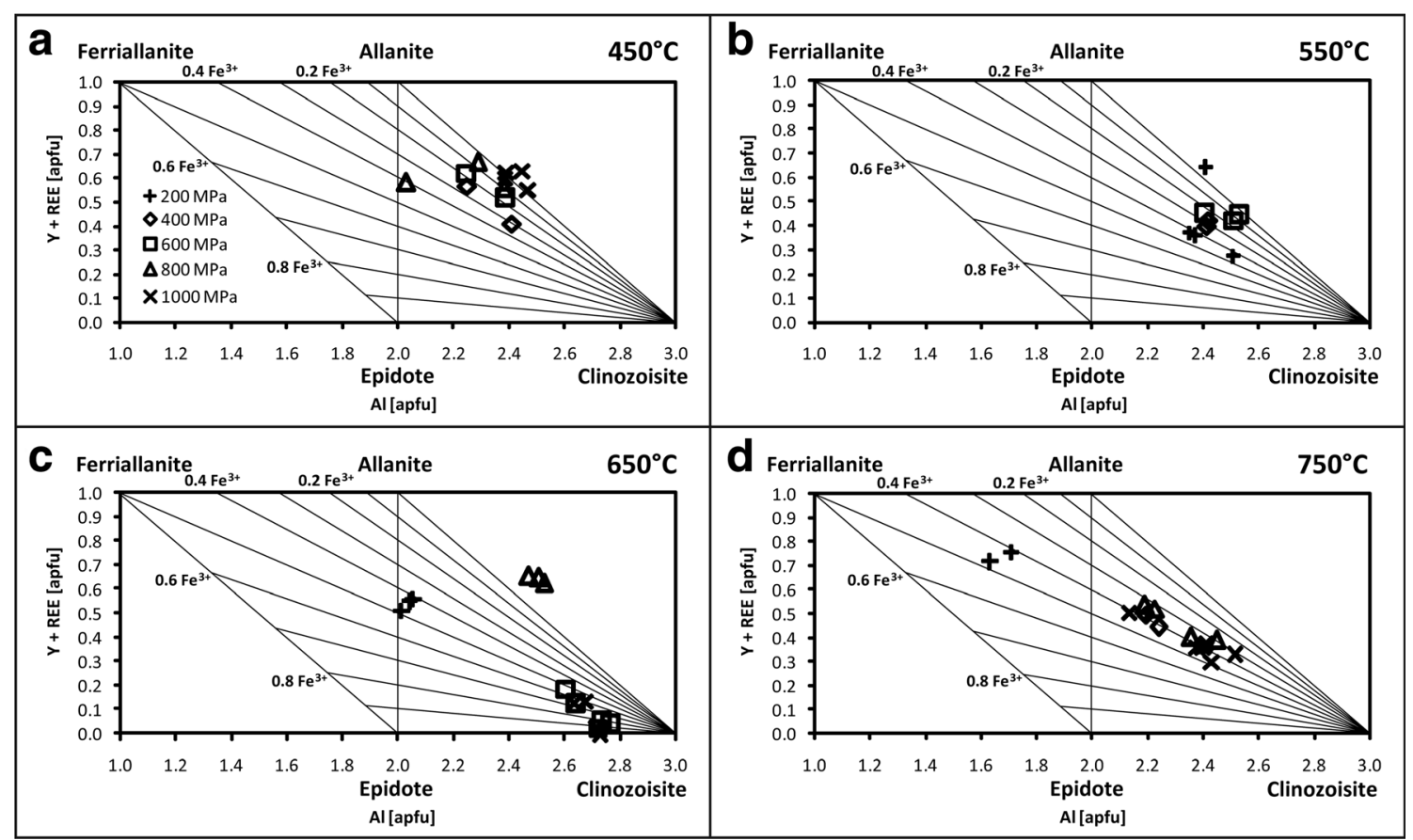

Fig. 6 Al versus Y + REE diagrams (after Petrík et al. 1995), which present compositional variations in the epidote-group minerals formed due to monazite-(Ce) breakdown in the experimental products from runs under temperature conditions of $450{ }^{\circ} \mathrm{C}(\mathbf{a}), 550{ }^{\circ} \mathrm{C}(\mathbf{b}), 650{ }^{\circ} \mathrm{C}(\mathbf{c})$, and $750{ }^{\circ} \mathrm{C}(\mathbf{d})$

$550{ }^{\circ} \mathrm{C}, 200$ and $400 \mathrm{MPa} ; 650{ }^{\circ} \mathrm{C}, 200$ and $400 \mathrm{MPa}$; and $750{ }^{\circ} \mathrm{C}, 200-1000 \mathrm{MPa}$, muscovite disappeared.

Garnet was preserved unreacted in all runs at 450,550, and $650{ }^{\circ} \mathrm{C}$ (supplementary Table S15). All experiments at $750^{\circ} \mathrm{C}, 200-1000 \mathrm{MPa}$ resulted in the breakdown of the garnet rims with partial replacement by low-Ti biotite (Fig. 10p). The remaining garnet cores preserved the original composition. Although the xenotime-(Y) experiments included garnet to test the partitioning of $\mathrm{Y}$ between xenotime-( $\mathrm{Y})$ and garnet in terms of geothermometric applications, no change in $\mathrm{Y}$ or HREE enrichment in garnet, compared to the original garnet, was found. This indicates that garnet was not a stable phase in the $750{ }^{\circ} \mathrm{C}$ experiments since it did not recrystallize and incorporate Y, HREE but rather broke down to biotite. In contrast, it was non-reactive in the lower temperature experiments either because it was a stable phase or more likely due to lower reaction rates such that the garnet was metastable.

Clinopyroxene formed in runs at $750{ }^{\circ} \mathrm{C}, 200-1000 \mathrm{MPa}$, where it occurs as euhedral crystals up to $4 \times 20 \mu \mathrm{m}$ in size (Fig. 10o). Titanite is found only in the high temperature runs with $2 \mathrm{M} \mathrm{Ca}(\mathrm{OH})_{2}$. It incorporates up to 3.91 wt. $\% \mathrm{Y}_{2} \mathrm{O}_{3}$ and 2.53 wt.\% $\mathrm{REE}_{2} \mathrm{O}_{3}$ (based on EDS analyses), presumably from the xenotime- $(\mathrm{Y})$.

Melt formed in runs at $650{ }^{\circ} \mathrm{C}, 200,800$, and $1000 \mathrm{MPa}$ (Fig. 10i and m); and in runs at $750{ }^{\circ} \mathrm{C}, 200-1000 \mathrm{MPa}$ (Fig. 10o and p). The melt composition consisted of 64.2671.45 wt. $\% \mathrm{SiO}_{2}, 10.58-14.79$ wt. $\% \mathrm{Al}_{2} \mathrm{O}_{3}, 0.20-4.66$ wt. $\%$ $\mathrm{CaO}, 0.08-1.32$ wt. $\% \mathrm{Na}_{2} \mathrm{O}$, and 0.77-1.94 wt. $\% \mathrm{~K}_{2} \mathrm{O}$, which defines a peraluminous character for the melt with an ASI $=$
2.6-4.0 (supplementary Table S16). The F content is 0.60 1.31 wt.\%. Similar to experiments with monazite-(Ce), the non-granitic melt is dominated by normative quartz (supplementary Fig. S1).

\section{Experiments with xenotime-(Y) and $\mathrm{Na}_{2} \mathrm{Si}_{2} \mathrm{O}_{5}+\mathrm{H}_{2} \mathrm{O}$}

All experiments with $\mathrm{Na}_{2} \mathrm{Si}_{2} \mathrm{O}_{5}+\mathrm{H}_{2} \mathrm{O}$ resulted in xenotime-(Y) breakdown and the formation of new phases (Table 3; Figs. 2, 12 and 13). The remaining fluid had a high $\mathrm{pH}$, except two runs in which the fluid had a neutral $\mathrm{pH}$ $\left(450{ }^{\circ} \mathrm{C}, 200 \mathrm{MPa}\right.$ and $550{ }^{\circ} \mathrm{C}, 400 \mathrm{MPa}$; Table 1$)$. Xenotime-(Y) shows dissolution pits and some etching on the surface. In all runs numerous crystals of Y-rich fluorcalciobritholite formed on the xenotime-(Y) surface as masses of individual grains, which overgrew and partially replaced the xenotime- $(\mathrm{Y})$ both on the surface and along internal fractures. In most of the $450-550{ }^{\circ} \mathrm{C}$ experiments, the xenotime-(Y) is occasionally preserved completely unreacted. In all runs, the remnant xenotime-(Y) reflects the composition of the starting NWFP xenotime-(Y), showing no compositional alteration (supplementary Table S10).

In all the runs, Y-rich fluorcalciobritholite formed euhedral to subhedral, hexagonal crystals whose size varied from a few microns in length to several microns thick and up to $100 \mu \mathrm{m}$ long. The size of crystals in the reaction rims was independent with respect to temperature conditions, whereas the amount of Y-rich fluorcalciobritholite formed increased with increasing temperature. Beside overgrowth and partial replacement of 

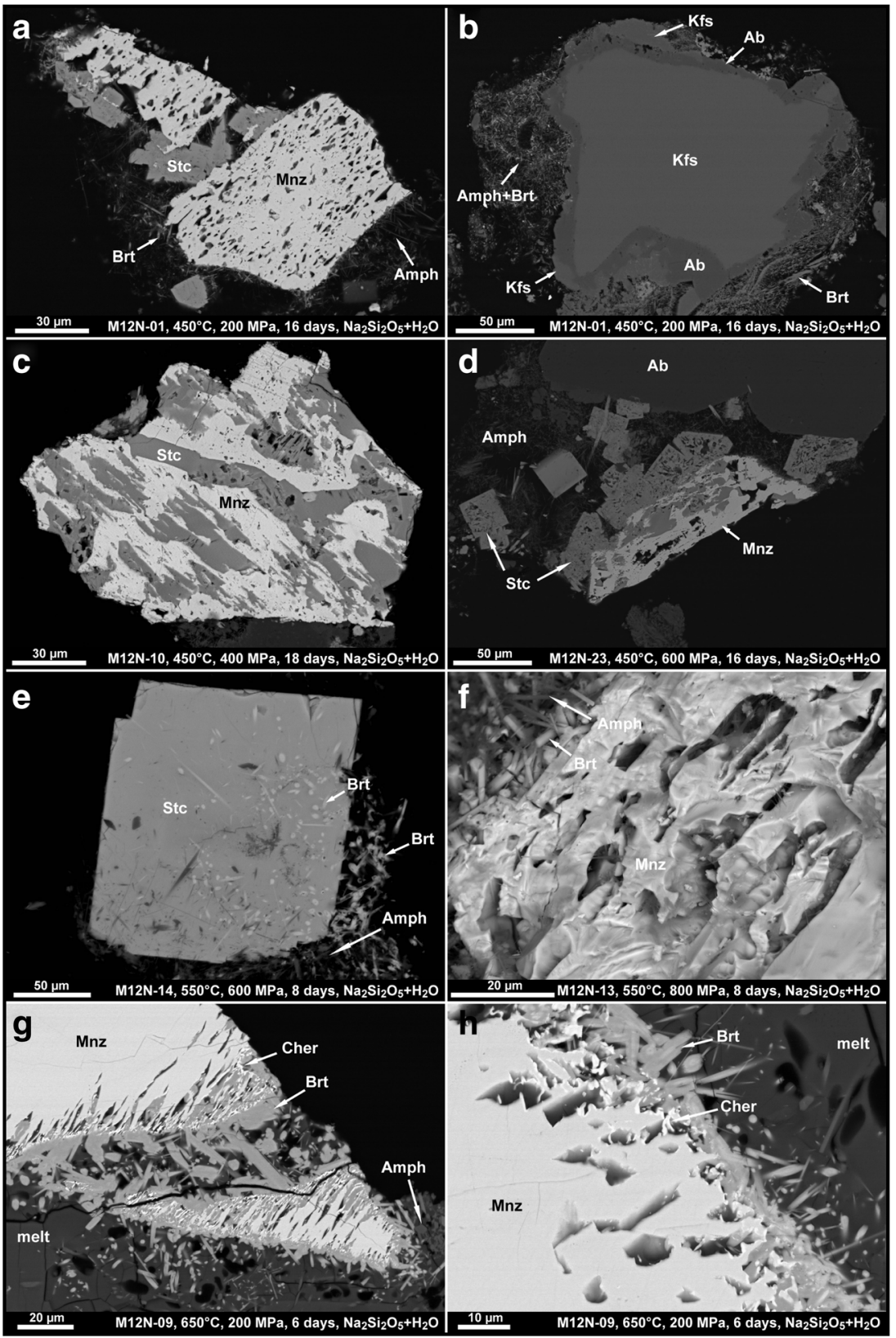

Fig. 7 BSE images presenting products from experiments with monazite-(Ce) and $\mathrm{Na}_{2} \mathrm{Si}_{2} \mathrm{O}_{5}+\mathrm{H}_{2} \mathrm{O}$; a altered monazite- $(\mathrm{Ce})$ with developed porosity, accompanied by secondary REE-rich steacyite and fluorcalciobritholite $\left(450^{\circ} \mathrm{C}, 200 \mathrm{MPa}, 16\right.$ days); b altered $\mathrm{K}$-feldspar with developed albite rim $\left(450{ }^{\circ} \mathrm{C}, 200 \mathrm{MPa}, 16\right.$ days); $\mathbf{c}$ altered monazite-(Ce) partially replaced by REE-rich steacyite $\left(450{ }^{\circ} \mathrm{C}, 400 \mathrm{MPa}\right.$, 18 days); d monazite-(Ce) partially replaced by REE-steacyite, which formed also individual crystals $\left(450{ }^{\circ} \mathrm{C}, 600 \mathrm{MPa}, 16\right.$ days); e large crystal of REE-rich steacyite with fluorcalciobritholite inclusions, formed at the expense of monazite-(Ce) $\left(550{ }^{\circ} \mathrm{C}, 600 \mathrm{MPa}, 8\right.$ days $)$; $\mathbf{f}$ altered surface of monazite-(Ce) overgrown by fluorcalciobritholite and amphibole; the porosity shows a rough parallel orientation $\left(550{ }^{\circ} \mathrm{C}, 800 \mathrm{MPa}\right.$, 8 days); $\mathbf{g}, \mathbf{h}$ altered monazite-(Ce) with a developed porosity oriented parallel to monazite- $(\mathrm{Ce})$ cleavage planes along the rims with

overgrowths of cheralite and fluorcalciobritholite $\left(650^{\circ} \mathrm{C}, 200 \mathrm{MPa}\right.$, 6 days); $\mathbf{i}$ altered monazite-(Ce) overgrown by fluorcalciobritholite prisms and partially mantled by melt $\left(650^{\circ} \mathrm{C}, 200 \mathrm{MPa}, 6\right.$ days $)$; j albite partially replaced by $\mathrm{K}$-feldspar with fluorcalciobritholite inclusions $\left(650{ }^{\circ} \mathrm{C}, 400 \mathrm{MPa}, 6\right.$ days); $\mathbf{k}, \mathbf{l}$ strongly altered monazite-(Ce) with oriented porosity, presumably along a preferred crystallographic direction or plane; the porosity is filled with secondary cheralite and fluorcalciobritholite $\left(650{ }^{\circ} \mathrm{C}, 1000 \mathrm{MPa}, 6\right.$ days); m sector zoning of REE-rich fluorapatite-fluorcalciobritholite prismatic crystals formed in melt at the expense of monazite-(Ce) $\left(650{ }^{\circ} \mathrm{C}, 1000 \mathrm{MPa}, 6\right.$ days); $\mathbf{n}$ altered monazite-(Ce) surface overgrown by REE-rich fluorapatitefluorcalciobritholite $\left(750{ }^{\circ} \mathrm{C}, 200 \mathrm{MPa}, 4\right.$ days); $\mathbf{0}$, p altered monazite(Ce) overgrown by fluorcalciobritholite mantled by melt $\left(750{ }^{\circ} \mathrm{C}\right.$, $1000 \mathrm{MPa}, 4$ days)

xenotime-(Y), Y-rich fluorcalciobritholite formed aggregates of individual grains commonly dispersed in the melt in the
650-750 ${ }^{\circ} \mathrm{C}$ runs (Fig. 12o). The Y-rich fluorcalciobritholite commonly shows sector zoning, related to crystal surface 

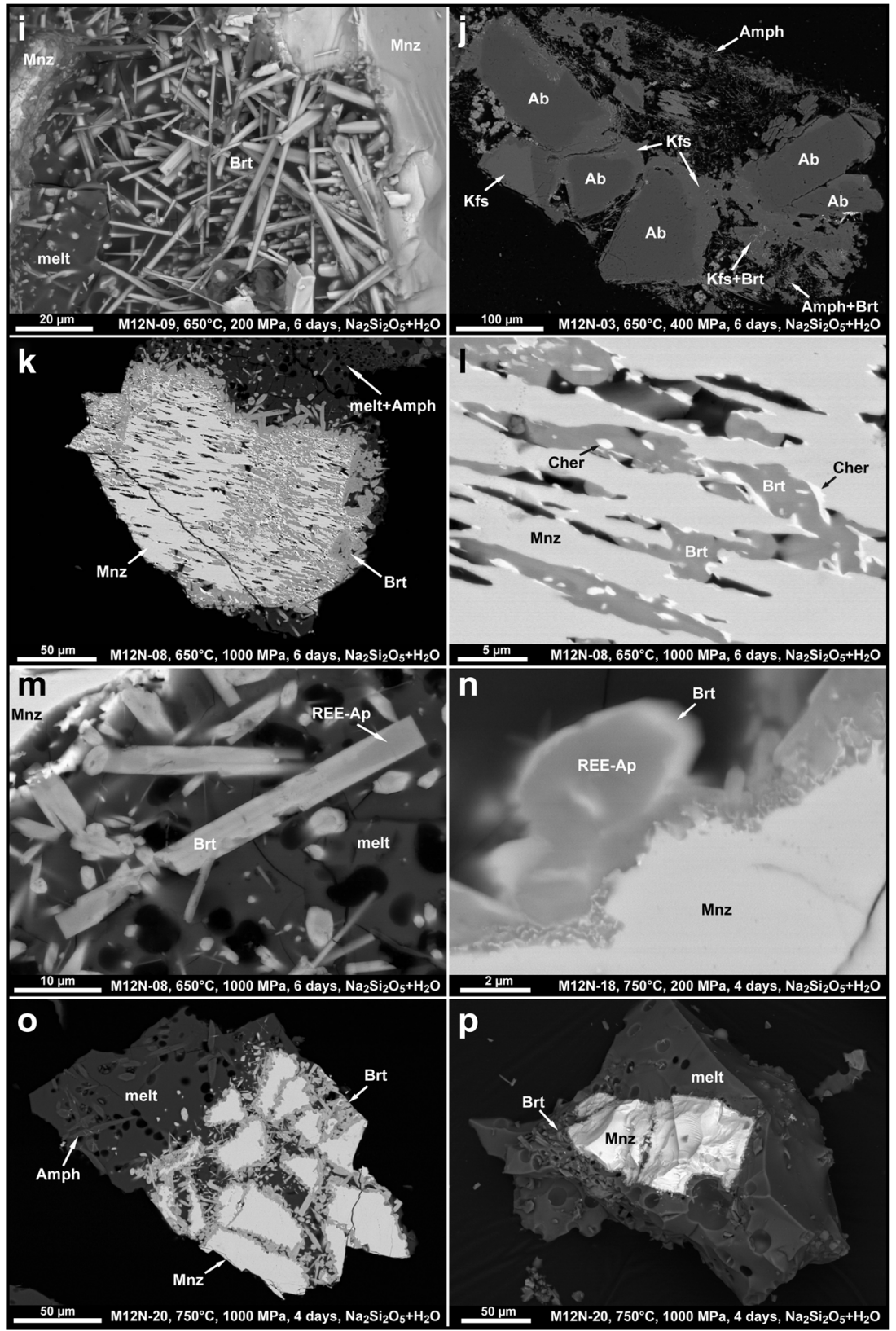

Fig. 7 (continued)

structure control of trace element incorporation (cf. Rakovan and Reeder 1996; Rakovan 2002), with (Y,REE)-rich fluorapatite cores and Y-rich fluorcalciobritholite rims (Fig. 12g and h; supplementary Table S11).

Albite was preserved in all the runs at 450, 550, and $650{ }^{\circ} \mathrm{C}$, but not in the $750{ }^{\circ} \mathrm{C}$ experiments. $\mathrm{K}$-feldspar rims formed on albite at $450{ }^{\circ} \mathrm{C}, 200-800 \mathrm{MPa}$; and at $550{ }^{\circ} \mathrm{C}, 200,600$, and $800 \mathrm{MPa}$ (supplementary Table S13). K-feldspar was found in the products from all 450,550 , and $6500^{\circ} \mathrm{C}$ runs, and in one run at $750{ }^{\circ} \mathrm{C}$, $600 \mathrm{MPa}$. Albite rims developed on K-feldspar in almost all the runs, i.e. $450{ }^{\circ} \mathrm{C}, 200-800 \mathrm{MPa} ; 550{ }^{\circ} \mathrm{C}, 200-$
$800 \mathrm{MPa} ; 650{ }^{\circ} \mathrm{C}, 400,800$, and $1000 \mathrm{MPa}$; and $750{ }^{\circ} \mathrm{C}$, $600 \mathrm{MPa}$ (supplementary Table S13).

Biotite is present unaltered in products from most runs. Only some starting biotite was preserved in the products from the $750{ }^{\circ} \mathrm{C}$ temperature experiments (Table 3). Secondary low-Ti biotite formed aggregates of small flakes in runs at $550{ }^{\circ} \mathrm{C}, 200 \mathrm{MPa} ; 650{ }^{\circ} \mathrm{C}$, 200-1000 MPa; and $750{ }^{\circ} \mathrm{C}, 200-1000 \mathrm{MPa}$ (Fig. 12k and $\mathrm{p}$; supplementary Table S14). Muscovite was present only in the products of four runs at $450{ }^{\circ} \mathrm{C}, 200$, 600,800 , and $1000 \mathrm{MPa}$, whereas it was not found in the products from the remaining experiments. 
Fig. 8 BSE image and compositional WDS X-ray maps of altered monazite-(Ce) from the $\mathrm{M} 12 \mathrm{~N}-23$ run at $450{ }^{\circ} \mathrm{C}$ and $600 \mathrm{MPa}$, with $\mathrm{Na}_{2} \mathrm{Si}_{2} \mathrm{O}_{5}+\mathrm{H}_{2} \mathrm{O}$; the monazite-(Ce) shows a porosity related to partial dissolution and patchy zoning formed due to fluid-mediated coupled dissolution-reprecipitation alteration; $A$ altered, $U$ unaltered

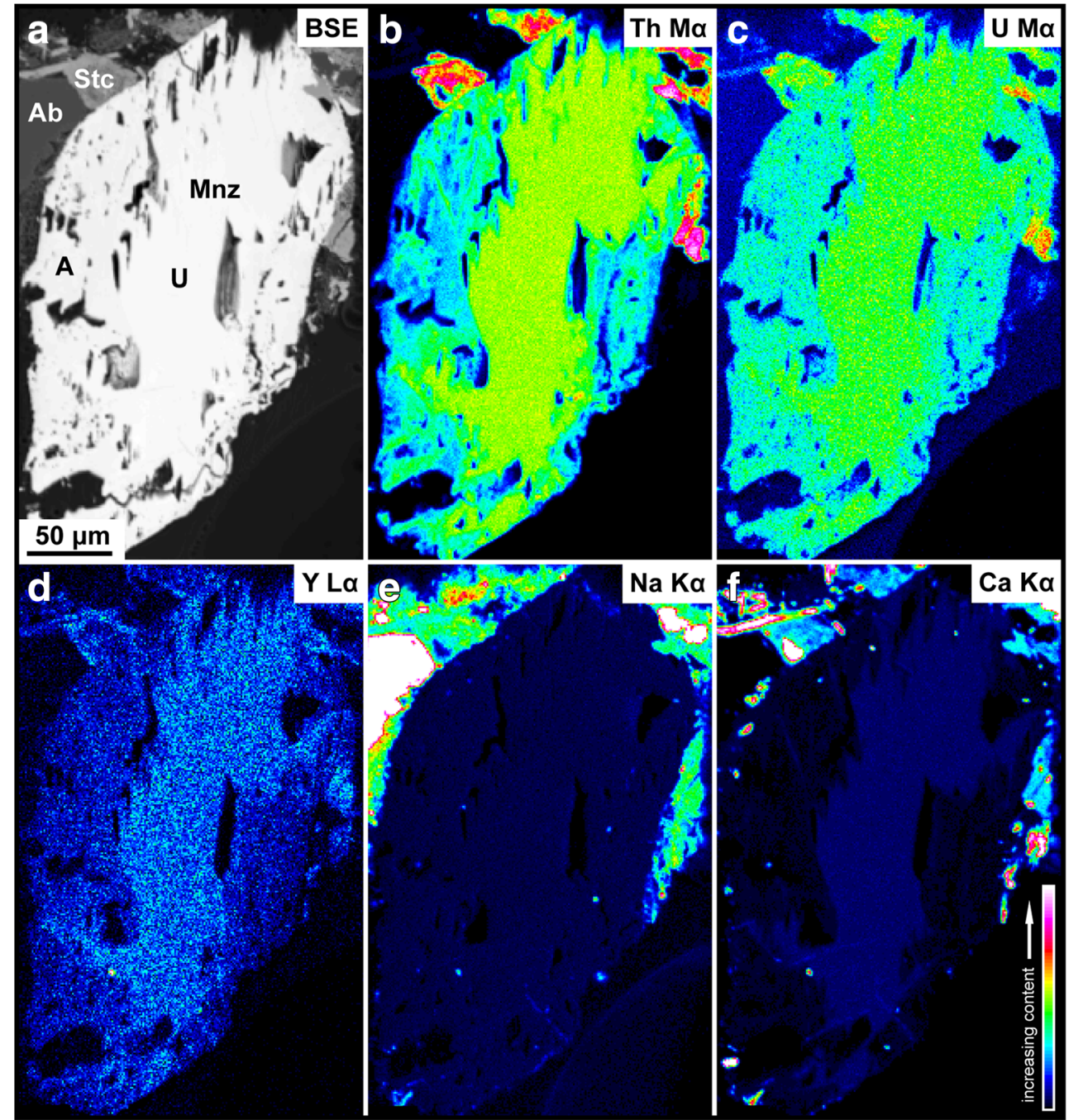

Garnet is preserved unaltered only in runs at $450{ }^{\circ} \mathrm{C}$, 200-1000 MPa. In runs at $550{ }^{\circ} \mathrm{C}$, the garnet grains reacted along the rims and fractures, with partial replacement by secondary low-Ti biotite, chlorite, and/or Na-K feldspar (Fig. 12c). The remaining garnet preserved the original composition (supplementary Table S15) indicating no recrystallization had occurred during partial alteration to biotite (supplementary Fig. S2). Garnet was not found in the products from runs at 650 and $750{ }^{\circ} \mathrm{C}$. Experiments under these temperature conditions resulted in complete breakdown of garnet judging from the presence of aggregates of secondary, low-Ti biotite and/or secondary albite occasionally forming post-garnet pseudomorphs.

Amphibole formed in all the runs. In runs at 450, 550, and $650{ }^{\circ} \mathrm{C}$, needle-like crystals of $\mathrm{Na}-(\mathrm{Fe}-\mathrm{Mg})$ amphiboles were identified using EDS analysis (Fig. 12a, b, g, $\mathrm{i}$ and 1). Experiments at $750{ }^{\circ} \mathrm{C}$ promoted the formation of amphibole grains up to $40 \mu \mathrm{m}$ across, with a composition similar to ferritaramite (Leake et al. 1997; Fig. 120 and p; supplementary Table S17).

Titanite was found in the products from experiments at $650{ }^{\circ} \mathrm{C}, 200,600,800$, and $1000 \mathrm{MPa}$; and $750{ }^{\circ} \mathrm{C}$, 200 and $1000 \mathrm{MPa}$. Commonly it forms small grains, although occasional grains, up to $150 \mu \mathrm{m}$ long and $40 \mu \mathrm{m}$ across, are present (Fig. 121). The titanite contains 5.07-6.30 wt.\% (Y + REE) ${ }_{2} \mathrm{O}_{3}$ (supplementary Table S18).

Melt formed in runs at $650{ }^{\circ} \mathrm{C}, 200,600,800$, and $1000 \mathrm{MPa}$ (Fig. 12g, h, k and 1), and $750{ }^{\circ} \mathrm{C}, 200$ $1000 \mathrm{MPa}$ (Fig. 12m-p). The non-granitic, peraluminous melt $(\mathrm{ASI}=1.9-4.7)$ contains $62.07-70.71$ wt. $\% \mathrm{SiO}_{2}$, 8.85-16.98 wt.\% $\mathrm{Al}_{2} \mathrm{O}_{3}, 0.15-1.96$ wt.\% $\mathrm{CaO}, 1.34$ 3.36 wt. $\% \mathrm{Na}_{2} \mathrm{O}$, and 1.46-2.07 $\mathrm{K}_{2} \mathrm{O}$ (supplementary Table S16). The F content is $0.86-2.06 \mathrm{wt} . \%$. The nongranitic melt is dominated by normative quartz with minor normative albite and orthoclase according to the QzAb-Or diagram (supplementary Fig. S1). 
Fig. 9 BSE image and compositional WDS X-ray maps of monazite-(Ce) partially replaced by REE-rich steacyite in experiment $\mathrm{M} 12 \mathrm{~N}-10$ at $450{ }^{\circ} \mathrm{C}$ and $400 \mathrm{MPa}$ with $\mathrm{Na}_{2} \mathrm{Si}_{2} \mathrm{O}_{5}+$ $\mathrm{H}_{2} \mathrm{O}$ fluid
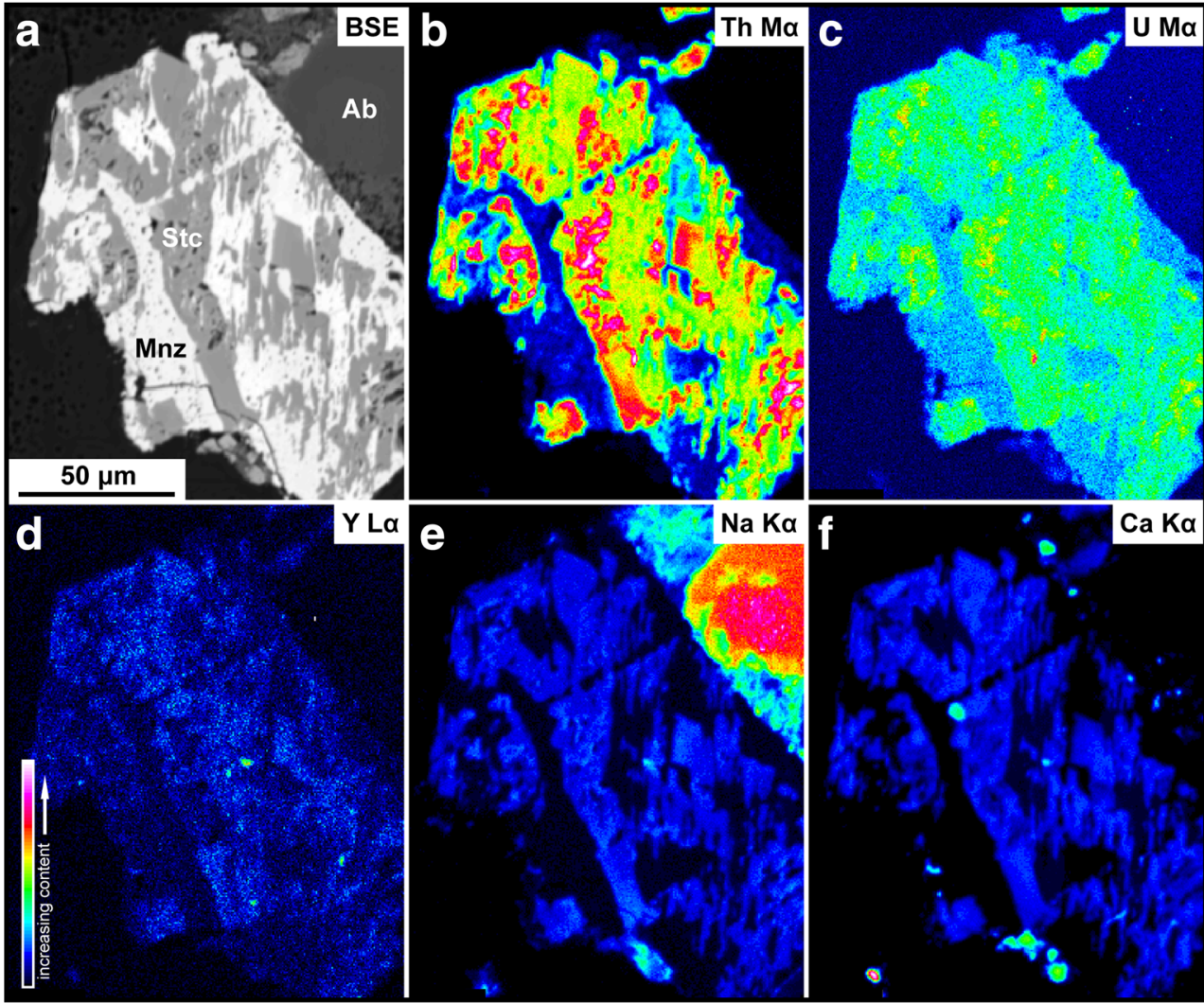

\section{Discussion}

\section{Interpretation of the experimental results: runs with monazite-(Ce)}

Similar to what was found in Budzyń et al. (2011), the results from these experiments demonstrate that the two fluids used were highly reactive with respect to both monazite-(Ce) and xenotime-(Y) over the broad P-T range considered. The neutral $\mathrm{pH}$ of the fluid in the $2 \mathrm{M} \mathrm{Ca}(\mathrm{OH})_{2}$ runs suggests that all of the $\mathrm{Ca}(\mathrm{OH})_{2}$ was used up as the main source of $\mathrm{Ca}$ for the apatites and REE-rich epidote-allanite-(Ce). This was the case except in the high pressure experiments at $450-550{ }^{\circ} \mathrm{C}$, where the remaining fluid still maintained a high $\mathrm{pH}$ suggesting slower reaction rates. In contrast, the high $\mathrm{pH}$ character of the remaining fluid from runs with $\mathrm{Na}_{2} \mathrm{Si}_{2} \mathrm{O}_{5}+\mathrm{H}_{2} \mathrm{O}$ indicates that not all the $\mathrm{Na}$ supplied by the $\mathrm{Na}_{2} \mathrm{Si}_{2} \mathrm{O}_{5}$ was used up.

Conversion of monazite-(Ce) to REE-rich epidote and allanite-(Ce), over the entire P-T range considered for the $2 \mathrm{M} \mathrm{Ca}(\mathrm{OH})_{2}$ experiments, indicates that the significantly increased Ca bulk content (10.08 wt.\% CaO; Table 2), compared to natural rocks of metapelitic to granitic composition [e.g. 2.17 wt.\% $\mathrm{CaO}$ for pelites; Shaw (1956)], was high enough to expand the stability field of allanite-(Ce) to at least $750{ }^{\circ} \mathrm{C}$ and $1000 \mathrm{MPa}$. At the same time, the relative size and abundance of the allanite-(Ce) grains increased with increasing temperature, though this was less dependent on pressure.
Here, monazite-(Ce) served as the source of REE for the REEepidote and allanite-(Ce). The chemical variability in either product phase is related to the coupled substitutions $\mathrm{REE}^{3+}$ $+\mathrm{Fe}^{2+}=\mathrm{Ca}^{2+}+\mathrm{Fe}^{3+}$ and $\mathrm{REE}^{3+}+\mathrm{Fe}^{2+}=\mathrm{Ca}^{2+}+\mathrm{Al}^{3+}($ Petrík et al. 1995). The data indicate high variations in the allanite-(Ce) REE content (Fig. 6), with significant enrichment in the $750{ }^{\circ} \mathrm{C}, 200 \mathrm{MPa}$ run.

REE-rich fluorapatite-fluorcalciobritholite also formed in most of the experiments due to the presence of monazite-(Ce) and $\mathrm{CaF}_{2}$. Differences in the apatite mineral chemistry and abundances in the experimental products are mainly related to the degree of monazite-(Ce) breakdown and the growth ratio of these phases, which are themselves related to increasing reaction kinetics with increasing temperature and pressure. Monazite-(Ce) breakdown to REE-rich fluorapatite-fluorcalciobritholite, and REE-epidoteallanite-(Ce), most likely occurred via the reaction monazite $-(\mathrm{Ce})+$ annite + quartz $+\mathrm{Ca}+\mathrm{F}$ (in fluid-I) $=$ fluorapatite + allanite-(Ce) + fluid-II (Broska and Siman 1998). Although in most of the runs biotite appears unaltered, some biotite, apart from the muscovite and feldspars, must have reacted as the primary source of $\mathrm{Fe}$ for the REEepidote and allanite-(Ce).

The unaltered monazite- $(\mathrm{Ce})$ cores demonstrate that the interior of the grains was shielded from fluid-aided alteration, except for partial dissolution near the surface, which occasionally progressed towards the cores of some of the 
Table 4 Overview of the products from runs with xenotime-(Y)

Set (3) xenotime- $(\mathrm{Y})+$ labradorite + sanidine + biotite + muscovite + garnet $+\mathrm{SiO}_{2}+\mathrm{CaF}_{2}+2 \mathrm{M} \mathrm{Ca}(\mathrm{OH})_{2}$

X12C-01, $450{ }^{\circ} \mathrm{C}, 200 \mathrm{MPa}, 16$ days. Xenotime-(Y) shows delicate dissolution, with small amounts of small crystals of Y-rich fluorcalciobritholite formed on the surface. Labradorite achieved Kfeldspar rims. K-feldspar, muscovite, biotite and garnet are preserved.

$\mathrm{X} 12 \mathrm{C}-10,450{ }^{\circ} \mathrm{C}, 400 \mathrm{MPa}, 18$ days. Xenotime-(Y) shows partial dissolution, with numerous small grains of Y-rich fluorcalciobritholite formed on the surface and in xenotime-(Y) fractures. Labradorite, $\mathrm{K}$ feldspar, biotite, muscovite and garnet are preserved.

$\mathrm{X} 12 \mathrm{C}-23,450{ }^{\circ} \mathrm{C}, 600 \mathrm{MPa}, 16$ days. Xenotime-(Y) shows partial dissolution, with small amounts of small crystals of Y-rich fluorcalciobritholite formed on the surface. Labradorite, K-feldspar, biotite, muscovite and garnet are preserved.

$\mathrm{X} 12 \mathrm{C}-16,450{ }^{\circ} \mathrm{C}, 800 \mathrm{MPa}, 16$ days. Xenotime-(Y) shows partial dissolution with small crystals of Y-rich fluorcalciobritholite formed on the surface. Occasionally most of the xenotime-(Y) is replaced by aggregate of Y-rich fluorcalciobritholite grains. Labradorite, K-feldspar, biotite, muscovite and garnet are preserved.

$\mathrm{X} 12 \mathrm{C}-17,450{ }^{\circ} \mathrm{C}, 1000 \mathrm{MPa}, 16$ days. Xenotime-(Y) shows partial dissolution, with small amounts of small crystals of Y-rich fluorcalciobritholite formed on the surface. Labradorite, K-feldspar, biotite, muscovite and garnet are preserved.

$\mathrm{X} 12 \mathrm{C}-06,550{ }^{\circ} \mathrm{C}, 200 \mathrm{MPa}, 12$ days. Xenotime-(Y) shows partial dissolution with Y-rich fluorcalciobritholite formed on the surface, partially replacing the xenotime-(Y). Labradorite achieved Kfeldspar rims. Starting biotite, K-feldspar and garnet are preserved. Muscovite is gone.

$\mathrm{X} 12 \mathrm{C}-02,550{ }^{\circ} \mathrm{C}, 400 \mathrm{MPa}, 6$ days. Xenotime-(Y) shows partial dissolution with Y-rich fluorcalciobritholite formed on the surface, partially replacing the xenotime-(Y). Labradorite achieved Kfeldspar rims. Starting biotite, K-feldspar and garnet are preserved. Muscovite is gone.

$\mathrm{X} 12 \mathrm{C}-14,550{ }^{\circ} \mathrm{C}, 600 \mathrm{MPa}, 8$ days. Xenotime-(Y) shows partial dissolution on the surface. High amounts of Y-rich fluorcalciobritholite formed on xenotime-(Y) surface, partially replacing the xenotime-(Y). Occasionally xenotime-(Y) is almost completely replaced by Y-rich fluorcalciobritholite. Starting labradorite, K-feldspar, biotite and garnet are preserved. Muscovite is gone.

$\mathrm{X} 12 \mathrm{C}-13,550{ }^{\circ} \mathrm{C}, 800 \mathrm{MPa}, 8$ days. Xenotime-(Y) shows partial dissolution on the surface. High amounts of Y-rich fluorcalciobritholite formed on xenotime-(Y) surface, partially replacing xenotime-(Y) along fractures. Several small grains of (Y,HREE)-rich epidote formed. Starting labradorite, Kfeldspar, biotite, muscovite and garnet are preserved. Occasionally labradorite achieved albite rims.

$\mathrm{X} 12 \mathrm{C}-07,550{ }^{\circ} \mathrm{C}, 1000 \mathrm{MPa}, 8$ days. Xenotime-(Y) shows partial dissolution on the surface. High amounts of Y-rich fluorcalciobritholite formed on xenotime-(Y) surface, partially replacing the xenotime-(Y). Starting labradorite, K-feldspar, biotite, muscovite and garnet are preserved. Occasionally labradorite achieved albite rims.

$\mathrm{X} 12 \mathrm{C}-09,650{ }^{\circ} \mathrm{C}, 200 \mathrm{MPa}, 6$ days. Xenotime-(Y) shows partial dissolution with high amounts of Y-rich fluorcalciobritholite formed on the surface, partially replacing the xenotime-(Y). Melt formed. Labradorite achieved K-feldspar rims. Garnet, biotite and $\mathrm{K}$-feldspar are preserved. Muscovite is gone.

$\mathrm{X} 12 \mathrm{C}-03,650{ }^{\circ} \mathrm{C}, 400 \mathrm{MPa}, 6$ days. Xenotime-(Y) shows partial dissolution with high amounts of Y-rich fluorcalciobritholite formed on the surface, partially replacing the xenotime-(Y). Labradorite, Kfeldspar, biotite and garnet are preserved. Muscovite is gone.
Table 4 (continued)

$\mathrm{X} 12 \mathrm{C}-12,650{ }^{\circ} \mathrm{C}, 600 \mathrm{MPa}, 6$ days. Xenotime-(Y) shows partial dissolution on the surface. High amounts of Y-rich fluorcalciobritholite formed on xenotime-(Y) surface, partially replacing the xenotime-(Y). Labradorite, K-feldspar, biotite, muscovite and garnet are preserved.

$\mathrm{X} 12 \mathrm{C}-11,650^{\circ} \mathrm{C}, 800 \mathrm{MPa}, 6$ days. High amounts of Y-rich fluorcalciobritholite formed on xenotime-(Y) surface, partially- to almost completely replacing the xenotime-(Y). Large grains of (Y,HREE)-rich epidote formed. Melt formed. Starting labradorite, K-feldspar, biotite, muscovite and garnet are preserved.

$\mathrm{X} 12 \mathrm{C}-08,650{ }^{\circ} \mathrm{C}, 1000 \mathrm{MPa}, 6$ days. Xenotime-(Y) shows partial dissolution on the surface. High amounts of Y-rich fluorcalciobritholite formed on xenotime-(Y) surface, partially replacing the xenotime-(Y). Large grains of (Y,HREE)-rich epidote formed. Melt formed. Aggregates of recrystallized muscovite are present. Some labradorite, K-feldspar, garnet and biotite are preserved.

$\mathrm{X} 12 \mathrm{C}-18,750{ }^{\circ} \mathrm{C}, 200 \mathrm{MPa}, 4$ days. Xenotime-(Y) shows partial dissolution on the surface. High amounts of Y-rich fluorcalciobritholite formed on xenotime-(Y) surface, partially replacing the xenotime-(Y). Melt formed. Single grains of pyroxene are present. Garnet rims are altered and replaced by secondary low-Ti biotite and Fe oxides. Some labradorite preserved. K-feldspar and muscovite are gone.

$\mathrm{X} 12 \mathrm{C}-19,750{ }^{\circ} \mathrm{C}, 400 \mathrm{MPa}, 4$ days. Xenotime-(Y) shows partial dissolution on the surface. High amounts of Y-rich fluorcalciobritholite formed on xenotime- $(\mathrm{Y})$ surface, partially replacing the xenotime-(Y). Melt formed. Feldspar with composition of bytownite forming porous grains filled with melt is present. Single grains of pyroxene are present. Some starting biotite preserved. Garnet rims display partial alteration and replacement by secondary low-Ti biotite. Altered labradorite developed porosity filled with melt. Labradorite, K-feldspar and muscovite are gone.

$\mathrm{X} 12 \mathrm{C}-22,7^{\circ}{ }^{\circ} \mathrm{C}, 600 \mathrm{MPa}, 4$ days. Xenotime-(Y) shows partial dissolution on the surface. High amounts of Y-rich fluorcalciobritholite formed on xenotime-(Y) surface, partially replacing the xenotime-(Y). Single grains of pyroxene are present. Some starting labradorite, biotite and garnet are preserved. Garnet rims display partial alteration and replacement by secondary low-Ti biotite/chlorite. K-feldspar and muscovite are gone.

$\mathrm{X} 12 \mathrm{C}-21,750{ }^{\circ} \mathrm{C}, 800 \mathrm{MPa}, 4$ days. Xenotime-(Y) shows partial dissolution on the surface. High amounts of Y-rich fluorcalciobritholite formed on xenotime-(Y) surface, partially replacing the xenotime-(Y). Melt formed. Feldspar with composition of bytownite forming porous grains filled with melt is present. Single grains of pyroxene are present. Some biotite preserved. Garnet rims display partial alteration and replacement by secondary low-Ti biotite. Labradorite, K-feldspar and muscovite are gone.

$\mathrm{X} 12 \mathrm{C}-20,750{ }^{\circ} \mathrm{C}, 1000 \mathrm{MPa}, 4$ days. Xenotime-(Y) shows partial dissolution on the surface. High amounts of Y-rich fluorcalciobritholite formed on xenotime-(Y) surface, partially replacing the xenotime-(Y). Melt formed. Feldspar with composition of bytownite forming porous grains filled with melt is present. Some biotite preserved. Garnet is partially altered, surrounded by secondary mica. Pyroxene and secondary low-Ti biotite formed. Labradorite, K-feldspar and muscovite are gone.

Set (4) xenotime-(Y) + albite + sanidine + biotite + muscovite + garnet $+\mathrm{SiO}_{2}+\mathrm{CaF}_{2}+\mathrm{Na}_{2} \mathrm{Si}_{2} \mathrm{O}_{5}+\mathrm{H}_{2} \mathrm{O}$

$\mathrm{X} 12 \mathrm{~N}-01,450{ }^{\circ} \mathrm{C}, 200 \mathrm{MPa}, 16$ days. Xenotime-(Y) shows partial dissolution on the surface. Small amounts of Y-rich fluorcalciobritholite formed on xenotime-(Y) surface. K-feldspar, garnet, biotite and muscovite are preserved. Albite achieved K-feldspar rims. Small grains of secondary feldspars with albite cores and K-feldspar rims formed. Delicate needle-like crystals of $\mathrm{Na}-(\mathrm{Fe}-\mathrm{Mg})$-amphibole are present. Garnet is not found.

$\mathrm{X} 12 \mathrm{~N}-10,450{ }^{\circ} \mathrm{C}, 400 \mathrm{MPa}, 18$ days. Xenotime-(Y) shows partial dissolution on the surface. Grains of (Y,REE)-rich fluorapatite and Y-rich fluorcalciobritholite formed, some on the surface of xenotime-(Y). Y-rich fluorcalciobritholite grains show sector 


\section{Table 4 (continued)}

zoning with (Y,REE)-rich fluorapatite cores and Y-rich fluorcalciobritholite rims. Garnet and biotite are preserved. Kfeldspar achieved albite rims. Albite achieved K-feldspar rims. Delicate needle-like crystals of $\mathrm{Na}-(\mathrm{Fe}-\mathrm{Mg})$-amphibole are present. Muscovite and garnet are not found.

$\mathrm{X} 12 \mathrm{~N}-23,450{ }^{\circ} \mathrm{C}, 600 \mathrm{MPa}, 16$ days. Xenotime-(Y) shows partial dissolution on the surface. Grains of (Y,REE)-rich fluorapatite and Y-rich fluorcalciobritholite formed, some on the surface of xenotime-(Y). Y-rich fluorcalciobritholite grains show sector zoning with (Y,REE)-rich fluorapatite cores and Y-rich fluorcalciobritholite rims. Garnet, biotite and muscovite are preserved. K-feldspar achieved albite rims. Albite achieved $\mathrm{K}$-feldspar rims. Delicate needle-like crystals of $\mathrm{Na}$-(Fe-Mg)-amphibole are present.

$\mathrm{X} 12 \mathrm{~N}-16,450{ }^{\circ} \mathrm{C}, 800 \mathrm{MPa}, 16$ days. Xenotime-(Y) shows partial dissolution on the surface. Y-rich fluorcalciobritholite formed on xenotime(Y) surface. Y-rich fluorcalciobritholite grains show sector zoning with (Y,REE)-rich fluorapatite cores and Y-rich fluorcalciobritholite rims. Garnet, biotite and muscovite are preserved. K-feldspar achieved albite rims. Albite achieved K-feldspar rims. Delicate needle-like crystals of Na-(Fe-Mg)-amphibole are present

$\mathrm{X} 12 \mathrm{~N}-17,450{ }^{\circ} \mathrm{C}, 1000 \mathrm{MPa}, 16$ days. Xenotime-(Y) shows partial dissolution on the surface. Y-rich fluorcalciobritholite formed on xenotime-(Y) surface, partially replacing the xenotime-(Y). Y-rich fluorcalciobritholite grains show sector zoning with (Y,REE)-rich fluorapatite cores and Y-rich fluorcalciobritholite rims. Starting albite, Kfeldspar, biotite, muscovite and garnet are present. Delicate needle-like crystals of $\mathrm{Na}-(\mathrm{Fe}-\mathrm{Mg})$-amphibole are present.

$\mathrm{X} 12 \mathrm{~N}-06,550{ }^{\circ} \mathrm{C}, 200 \mathrm{MPa}, 12$ days. Xenotime-(Y) shows partial dissolution on the surface. Y-rich fluorcalciobritholite formed on xenotime-(Y) surface, partially replacing the xenotime-(Y). Biotite is preserved. K-feldspar achieved albite rims. Albite achieved K-feldspar rims. Garnet achieved secondary mica rims. Delicate needle-like crystals of $\mathrm{Na}-(\mathrm{Fe}-\mathrm{Mg})$-amphibole are present. Muscovite is gone.

$\mathrm{X} 12 \mathrm{~N}-02,550{ }^{\circ} \mathrm{C}, 400 \mathrm{MPa}, 6$ days. Xenotime-(Y) shows partial dissolution on the surface. Y-rich fluorcalciobritholite formed on xenotime- $(\mathrm{Y})$ surface, partially replacing the xenotime- $(\mathrm{Y})$. Biotite is preserved. Albite achieved K-feldspar rims. K-feldspar achieved albite rims. Garnet rims are altered and partially replaced by secondary mica. Delicate needle-like crystals of $\mathrm{Na}-(\mathrm{Fe}-\mathrm{Mg})$-amphibole are present. Muscovite is gone.

$\mathrm{X} 12 \mathrm{~N}-14,550{ }^{\circ} \mathrm{C}, 600 \mathrm{MPa}, 8$ days. Xenotime-(Y) shows partial dissolution on the surface. Y-rich fluorcalciobritholite formed on xenotime-(Y) surface, partially replacing the xenotime-(Y). Y-rich fluorcalciobritholite grains show sector zoning with (Y,REE)-rich fluorapatite cores and Y-rich fluorcalciobritholite rims. Biotite is preserved. Albite is partially replaced by K-feldspar. K-feldspar achieved albite rims. Garnet is partially altered, with secondary mica and $\mathrm{Na}-\mathrm{K}$ feldspar formed. Delicate needle-like crystals of Na-(Fe-Mg)-amphibole are present. Muscovite is gone.

$\mathrm{X} 12 \mathrm{~N}-13,550{ }^{\circ} \mathrm{C}, 800 \mathrm{MPa}, 8$ days. Xenotime-(Y) shows partial dissolution on the surface. High amounts of Y-rich fluorcalciobritholite formed on xenotime-(Y) surface, partially replacing the xenotime-(Y). Y-rich fluorcalciobritholite grains show sector zoning with (Y,REE)-rich fluorapatite cores and Y-rich fluorcalciobritholite rims. Garnet and biotite are preserved. Albite rims are strongly corroded with developed porosity. K-feldspar achieved albite rims. Delicate needle-like crystals of $\mathrm{Na}-(\mathrm{Fe}-\mathrm{Mg})$ amphibole are present. Muscovite is gone.

$\mathrm{X} 12 \mathrm{~N}-07,550{ }^{\circ} \mathrm{C}, 1000 \mathrm{MPa}, 8$ days. Xenotime-(Y) shows partial dissolution on the surface. High amounts of Y-rich fluorcalciobritholite formed on xenotime-(Y) surface, partially replacing the xenotime-(Y). Yrich fluorcalciobritholite grains show sector zoning with (Y,REE)-rich fluorapatite cores and Y-rich fluorcalciobritholite rims. Albite, K-feldspar and biotite are preserved. Some K-feldspar achieved albite rims. Delicate
Table 4 (continued)

needle-like crystals of $\mathrm{Na}-(\mathrm{Fe}-\mathrm{Mg})$-amphibole are present. Muscovite is gone.

$\mathrm{X} 12 \mathrm{~N}-09,650{ }^{\circ} \mathrm{C}, 200 \mathrm{MPa}, 6$ days. Xenotime-(Y) shows partial dissolution on the surface. High amounts of Y-rich fluorcalciobritholite formed on xenotime-(Y) surface, partially replacing the xenotime-(Y). Yrich fluorcalciobritholite grains show sector zoning with (Y,REE)-rich fluorapatite cores and Y-rich fluorcalciobritholite rims. Melt formed. Some starting albite, K-feldspar and biotite are preserved. Albite achieved $\mathrm{Na}-\mathrm{K}$ feldspar rims. Titanite formed. Aggregates of secondary low-Ti biotite and secondary albite form post-garnet pseudomorphs. Delicate needle-like crystals of $\mathrm{Na}-(\mathrm{Fe}-\mathrm{Mg})$-amphibole are present. Garnet and muscovite are gone.

$\mathrm{X} 12 \mathrm{~N}-03,650{ }^{\circ} \mathrm{C}, 400 \mathrm{MPa}, 6$ days. Xenotime-(Y) shows partial dissolution on the surface. Y-rich fluorcalciobritholite formed on xenotime(Y) surface, partially replacing the xenotime-(Y). Biotite is preserved. Albite achieved K-feldspar rims. K-feldspar achieved albite rims. Aggregates of secondary low-Ti biotite and secondary albite form post-garnet pseudomorphs. Delicate needle-like crystals of $\mathrm{Na}-(\mathrm{Fe}-\mathrm{Mg})$-amphibole are present. Garnet and muscovite are gone.

$\mathrm{X} 12 \mathrm{~N}-12,650{ }^{\circ} \mathrm{C}, 600 \mathrm{MPa}, 6$ days. Xenotime-(Y) shows partial dissolution on the surface. High amounts of Y-rich fluorcalciobritholite formed on xenotime-(Y) surface, partially replacing the xenotime-(Y). Melt formed. Some starting albite, K-feldspar and biotite are preserved. Aggregates of secondary low-Ti biotite are present in melt. Titanite formed. Delicate needle-like crystals of $\mathrm{Na}-(\mathrm{Fe}-\mathrm{Mg})$-amphibole are present. Garnet and muscovite are gone.

$\mathrm{X} 12 \mathrm{~N}-11,650{ }^{\circ} \mathrm{C}, 800 \mathrm{MPa}, 6$ days. Xenotime-(Y) shows partial dissolution on the surface. High amounts of Y-rich fluorcalciobritholite formed on xenotime-(Y) surface, partially replacing the xenotime-(Y). Yrich fluorcalciobritholite grains show sector zoning with (Y,REE)-rich fluorapatite cores and Y-rich fluorcalciobritholite rims. Albite and biotite are preserved. Some K-feldspar is preserved with developed albite rims. Melt formed. Aggregates of secondary low-Ti biotite are present in melt. Titanite formed. Delicate needle-like crystals of $\mathrm{Na}-(\mathrm{Fe}-\mathrm{Mg})$-amphibole are present. Garnet and muscovite are gone.

$\mathrm{X} 12 \mathrm{~N}-08,650{ }^{\circ} \mathrm{C}, 1000 \mathrm{MPa}, 6$ days. Xenotime-(Y) shows partial dissolution on the surface. High amounts of Y-rich fluorcalciobritholite formed on xenotime-(Y) surface, partially replacing the xenotime-(Y). Melt formed. Some albite, garnet and biotite are preserved. Some Kfeldspar is preserved with developed albite rims. Aggregates of secondary low-Ti biotite are present in melt. Titanite formed. Delicate needle-like crystals of $\mathrm{Na}-(\mathrm{Fe}-\mathrm{Mg})$-amphibole are present. Garnet and muscovite are gone.

$\mathrm{X} 12 \mathrm{~N}-18,750{ }^{\circ} \mathrm{C}, 200 \mathrm{MPa}, 4$ days. Xenotime-(Y) shows partial dissolution on the surface. Y-rich fluorcalciobritholite formed on xenotime(Y) surface, partially replacing the xenotime-(Y). Melt formed. Some starting biotite preserved. Secondary low-Ti biotite and pyroxene formed. Small crystals with composition of $\mathrm{Na}-(\mathrm{Fe}-\mathrm{Mg})$-amphibole are present. K-feldspar, albite, garnet, and muscovite are gone.

$\mathrm{X} 12 \mathrm{~N}-19,750{ }^{\circ} \mathrm{C}, 400 \mathrm{MPa}, 4$ days. Xenotime-(Y) shows partial dissolution on the surface. Y-rich fluorcalciobritholite formed on xenotime-(Y) surface, partially replacing the xenotime-(Y). Melt formed. Some starting biotite preserved. Secondary low-Ti biotite formed. Small crystals with composition of $\mathrm{Na}-(\mathrm{Fe}-\mathrm{Mg})$-amphibole are present. $\mathrm{K}$-feldspar, albite, garnet and muscovite are gone.

$\mathrm{X} 12 \mathrm{~N}-22,750{ }^{\circ} \mathrm{C}, 600 \mathrm{MPa}, 4$ days. Xenotime-(Y) shows partial dissolution on the surface. Y-rich fluorcalciobritholite formed on xenotime-(Y) surface, partially replacing the xenotime-(Y). Melt formed. Aggregates of secondary low-Ti biotite are present in melt. Some starting albite preserved. Small crystals of amphibole with composition close to ferri-taramite are present. K-feldspar, garnet and muscovite are gone.

$\mathrm{X} 12 \mathrm{~N}-21,750{ }^{\circ} \mathrm{C}, 800 \mathrm{MPa}, 4$ days. Xenotime-(Y) shows partial dissolution on the surface. Y-rich fluorcalciobritholite formed on 
Table 4 (continued)

xenotime-(Y) surface, partially replacing the xenotime-(Y). Melt formed. Pyroxene crystals are present in melt. Small crystals of amphibole with composition close to ferri-taramite are present. K-feldspar, albite, garnet and muscovite are gone.

$\mathrm{X} 12 \mathrm{~N}-20,750^{\circ} \mathrm{C}, 1000 \mathrm{MPa}, 4$ days. Xenotime-(Y) shows partial dissolution on the surface. High amounts of Y-rich fluorcalciobritholite formed on xenotime-(Y) surface, partially replacing the xenotime-(Y). Melt formed. Aggregates of secondary biotite are present in melt. Titanite formed. Small crystals of amphibole with composition close to ferritaramite are present. K-feldspar, albite, garnet, and muscovite are gone.

monazite-(Ce) grains from the 650 and $750{ }^{\circ} \mathrm{C}$ runs (Fig. 31). These alteration textures are the result of coupled dissolutionreprecipitation, which is induced by a fluid front infiltrating the parent phase, and leaving behind a chemically altered phase (Putnis 2002, 2009; Harlov et al. 2011; Putnis and Austrheim 2012). In nature, coupled dissolutionreprecipitation is widely recognized as being responsible for mineral replacement reactions and pseudomorphism (Putnis 2002, 2009). The pseudomorphic replacement of the monazite-(Ce) by REE-rich fluorapatite-fluorcalciobritholite required a supply of external components $(\mathrm{Si}, \mathrm{Ca}, \mathrm{F})$ from the fluid into the altered areas of the monazite-(Ce). The textural setting of the reaction phases replacing monazite-(Ce) (Fig. 3e, g, h and $\mathrm{m}$ ) indicates that local REE, Th, and $\mathrm{U}$, released from the altered monazite-(Ce), were incorporated into the newly formed apatites.

Partial replacement of monazite-(Ce) grains in these experiments, occasionally takes the form of a succession of REE-bearing minerals in the form of a corona (Fig. $3 \mathrm{~m}$ ). In this succession, REE-rich fluorapatitefluorcalciobritholite forms in close contact to the monazite-(Ce), followed by allanite-(Ce). The outer part of corona-like texture consists of REE-rich epidote overgrowing the allanite-(Ce). The corona demonstrates the limited distance over which REE mobilization occurs as reflected by the decreasing REE content in the sequence of secondary phases surrounding the monazite-(Ce). Similar conclusions have been made for natural examples of the partial- to complete replacement of monazite by a sequence of apatite, allanite, and epidote zones in metamorphosed granitic rocks and pelites (e.g. Broska and Siman 1998; Finger et al. 1998; Broska et al. 2005; Majka and Budzyń 2006; Petrík et al. 2006; Budzyń et al. 2010; Ondrejka et al. 2012; Budzyń and Jastrzębski 2016; Finger et al. 2016; Lo Pò et al. 2016). The occurrence of $\mathrm{ThSiO}_{4}$ or $\mathrm{ThO}_{2}$ only in the inner zone mantling the monazite, as inclusions in apatite (Finger et al. 1998; Ondrejka et al. 2012; Budzyń et al. 2010), indicates that Th transport occurs over a much more limited distance from the monazite compared to the REEs.
The similar form and size of REE-rich fluorapatitefluorcalciobritholite crystals in all the experiments indicate that their growth is relatively independent of the P-T conditions, although higher amounts of these crystals formed in high temperature runs with $\mathrm{Na}_{2} \mathrm{Si}_{2} \mathrm{O}_{5}+\mathrm{H}_{2} \mathrm{O}$, where REErich fluorapatite-fluorcalciobritholite were the primary phases replacing monazite-(Ce) (cf. Figs. 7a and e vs. 7f-p). REE enrichment in the product apatites is the result of two coupled substitution reactions $\mathrm{REE}^{3+}+\mathrm{Si}^{4+}=\mathrm{Ca}^{2+}+\mathrm{P}^{5+}$ and $\mathrm{REE}^{3+}+$ $\mathrm{Na}^{+}=2 \mathrm{Ca}^{2+}$ (Pan and Fleet 2002). REE substitution into apatites from the $2 \mathrm{M} \mathrm{Ca}(\mathrm{OH})_{2}$ experiments is dominated by $\mathrm{Si}\left(12.23-15.59\right.$ wt. $\% \mathrm{SiO}_{2},<0.01$ wt. $\left.\% \mathrm{Na}_{2} \mathrm{O}\right)$, whereas both REE substitutions occur in apatites from the runs with $\mathrm{Na}_{2} \mathrm{Si}_{2} \mathrm{O}_{5}+\mathrm{H}_{2} \mathrm{O}\left(0.82-15.62\right.$ wt. $\% \mathrm{SiO}_{2}, 0.58-4.52$ wt. $\%$ $\mathrm{Na}_{2} \mathrm{O}$; supplementary Table $\mathrm{S} 3$ ). An increase in the REE concentration in apatite from the $2 \mathrm{M} \mathrm{Ca}(\mathrm{OH})_{2}$ experiments from 27.66 to 44.09 wt. $\%(\mathrm{Y}+\mathrm{REE})_{2} \mathrm{O}_{3}$ in runs from 450 to $750{ }^{\circ} \mathrm{C}$ (supplementary Table S3) indicates a direct correlation with increasing temperature conditions. The apatites from the experiments with $\mathrm{Na}_{2} \mathrm{Si}_{2} \mathrm{O}_{5}+\mathrm{H}_{2} \mathrm{O}$ show similar increase from 14.25 to $39.47 \mathrm{wt} . \%(\mathrm{Y}+\mathrm{REE})_{2} \mathrm{O}_{3}$ in the $450-550{ }^{\circ} \mathrm{C}$ runs to 36.94-42.60 wt. \% $(\mathrm{Y}+\mathrm{REE})_{2} \mathrm{O}_{3}$ in the $650-750{ }^{\circ} \mathrm{C}$ runs (supplementary Table S3). These results also support those of Krenn et al. (2012) in a series of monazite-allanitefluorapatite experiments. Krenn et al. (2012) documented an increase in the $\mathrm{Na}_{2} \mathrm{O}-\mathrm{SiO}_{2}-(\mathrm{Y}+\mathrm{REE})_{2} \mathrm{O}_{3}$ content in fluorapatite [0.17-4.86 wt. $\% \mathrm{SiO}_{2}, 0.47-3.38$ wt. $\% \mathrm{Na}_{2} \mathrm{O}$, 2.53-29.19 wt. $\%(\mathrm{Y}+\mathrm{REE})_{2} \mathrm{O}_{3}$ ] with an increase in the pressure and temperature from 0.5 to $4 \mathrm{GPa}$ and 650 to $900{ }^{\circ} \mathrm{C}$. These experiments, along with the results from this study, support previous work suggesting that high activities of $\mathrm{Si}$ and $\mathrm{Na}$ in the fluid/melt promote the incorporation of REEs into apatite ( $\mathrm{Pan}$ and Fleet 2002).

In the $\mathrm{Na}_{2} \mathrm{Si}_{2} \mathrm{O}_{5}+\mathrm{H}_{2} \mathrm{O}$ experiments, the altered domains in the monazite-(Ce) are characterized by a fluid-induced, pervasive, interconnected nano- and micro-porosity (Figs. 7a and c and 8), which is characteristic of a coupled dissolutionreprecipitation process (Putnis 2002, 2009; Harlov et al. 2007, 2011; Putnis and Austrheim 2012). These domains are also characterized by depletion in Th and $\mathrm{U}$, and the almost complete removal of $\mathrm{Pb}$ (supplementary Table S1) in runs at $450{ }^{\circ} \mathrm{C}, 200-1000 \mathrm{MPa}$; and $550^{\circ} \mathrm{C}, 200-600 \mathrm{MPa}$. In runs at higher P-T conditions, a fluid-induced porosity occurs, along with numerous tiny inclusions of cheralite, apparently oriented parallel to a specific crystallographic plane in the monazite-(Ce) (Fig. 7g, k and 1). The Burnet monazite-(Ce) (11.43 wt. $\% \mathrm{ThO}_{2}, 0.34$ wt. $\% \mathrm{UO}_{2}, 0.59$ wt. $\% \mathrm{PbO}$ ), used in these experiments, is relatively rich in Th, which would imply a greater degree of metamictization, and therefore a greater susceptibility to fluid-aided alteration via coupled dissolution-reprecipitation.

In the experiments utilizing $\mathrm{Na}_{2} \mathrm{Si}_{2} \mathrm{O}_{5}+\mathrm{H}_{2} \mathrm{O}$, altered domains in the monazite-(Ce) from the $450-550{ }^{\circ} \mathrm{C}$ experiments 

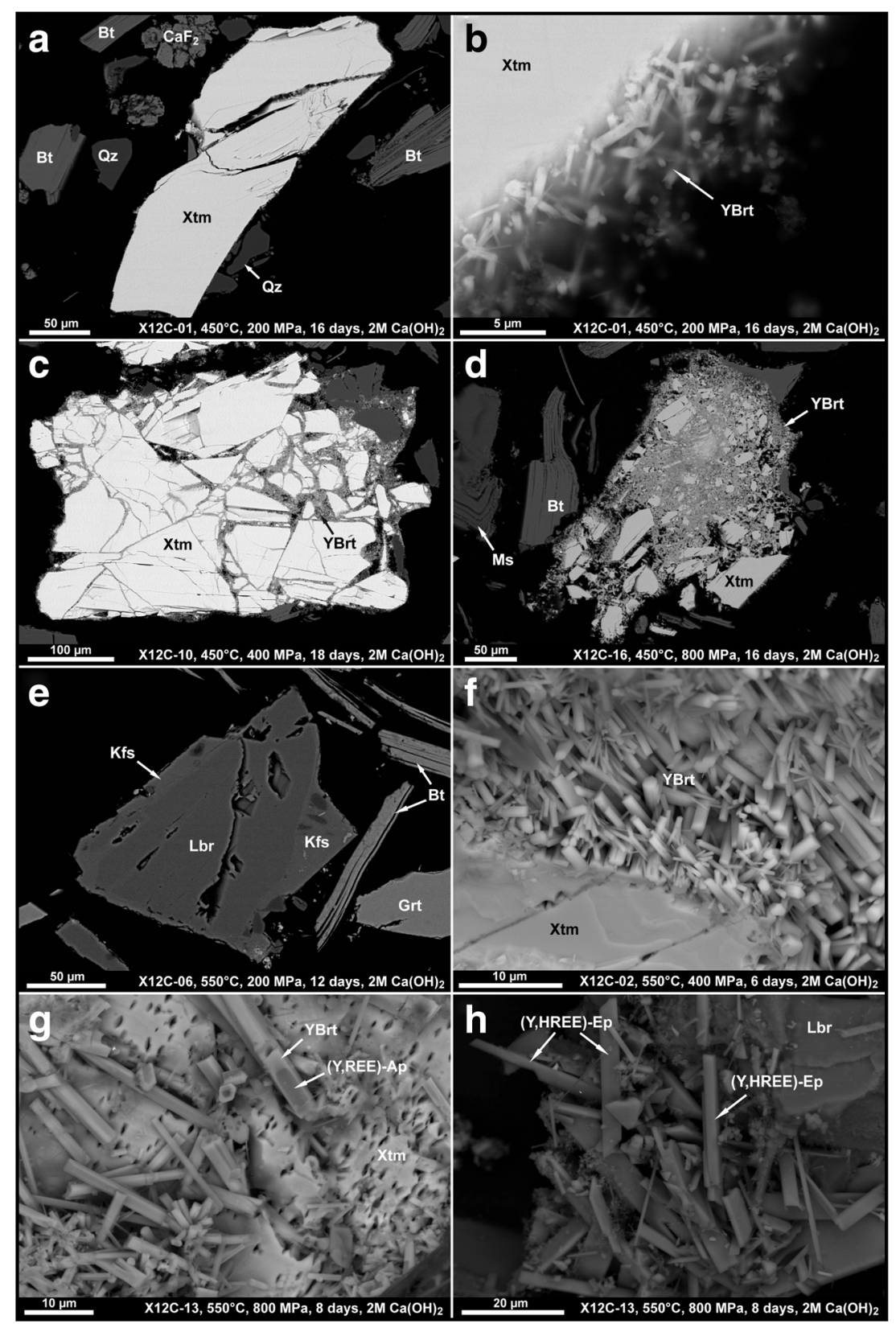

Fig. 10 BSE images of run products from experiments with xenotime(Y) and $2 \mathrm{M} \mathrm{Ca}(\mathrm{OH})_{2}$; a, b slightly altered xenotime-( $\mathrm{Y}$ ) overgrown by small crystals of Y-rich fluorcalciobritholite $\left(450{ }^{\circ} \mathrm{C}, 200 \mathrm{MPa}, 16\right.$ days); c fractured xenotime-(Y) with Y-rich fluorcalciobritholite filling the fractures $\left(450{ }^{\circ} \mathrm{C}, 400 \mathrm{MPa}, 18\right.$ days); $\mathbf{d}$ Y-rich fluorcalciobritholite almost completely replacing altered xenotime-(Y) $\left(450{ }^{\circ} \mathrm{C}, 800 \mathrm{MPa}, 16\right.$ days); e labradorite partially replaced by K-feldspar $\left(550^{\circ} \mathrm{C}, 200 \mathrm{MPa}, 12\right.$ days $) ; \mathbf{f}$ numerous hexagonal prisms of Y-rich fluorcalciobritholite formed on the surface of the xenotime-(Y) $\left(550{ }^{\circ} \mathrm{C}, 400 \mathrm{MPa}, 6\right.$ days); $\mathbf{g}$ hexagonal, sector-zoned, prismatic crystals of (Y,REE)-rich fluorapatite and Y-rich fluorcalciobritholite, which have formed on the xenotime-(Y) surface $\left(550{ }^{\circ} \mathrm{C}, 800 \mathrm{MPa}, 8\right.$ days); $\mathbf{h}$ (Y,HREE)-rich epidote formed at the expense of altered xenotime-(Y) (hexagonal prisms of Y-rich

fluorcalciobritholite formed on the xenotime-(Y) surface $\left(550{ }^{\circ} \mathrm{C}\right.$, $800 \mathrm{MPa}, 8$ days); $\mathbf{i}, \mathbf{j}$ Y-rich fluorcalciobritholite overgrowths on altered xenotime-(Y) $\left(650{ }^{\circ} \mathrm{C}, 200 \mathrm{MPa}, 6\right.$ days); $\mathbf{k}$ (Y,HREE)-rich epidote formed at the expense of altered xenotime-(Y) in experiments at $650{ }^{\circ} \mathrm{C}, 800 \mathrm{MPa}, 6$ days (k) and $650{ }^{\circ} \mathrm{C}, 1000 \mathrm{MPa}, 6$ days (l); $\mathbf{m}$ altered xenotime-(Y) overgrown by Y-rich fluorcalciobritholite $\left(650^{\circ} \mathrm{C}\right.$, $1000 \mathrm{MPa}, 6$ days); $\mathbf{n}$ recrystallized muscovite in run at $650{ }^{\circ} \mathrm{C}$, $1000 \mathrm{MPa}, 6$ days; 0 small crystals of pyroxene formed in melt $\left(750{ }^{\circ} \mathrm{C}, 1000 \mathrm{MPa}, 4\right.$ days); $\mathbf{p}$ slightly altered xenotime-(Y) with overgrowths of minute Y-rich fluorcalciobritholite crystals $\left(750^{\circ} \mathrm{C}, 200 \mathrm{MPa}\right.$, 4 days); altered garnet is partially replaced by an aggregate of secondary low-Ti biotite and iron oxides

supplied Th and REE to the REE-rich steacyite, REE-rich fluorapatite, and Y-rich fluorcalciobritholite. The textural setting indicates that the Th was either transported by the fluid to form individual crystals of REE-rich steacyite, or that transport of Th was limited and REE-rich steacyite partially replaced monazite-(Ce). In the experimental replacement of 

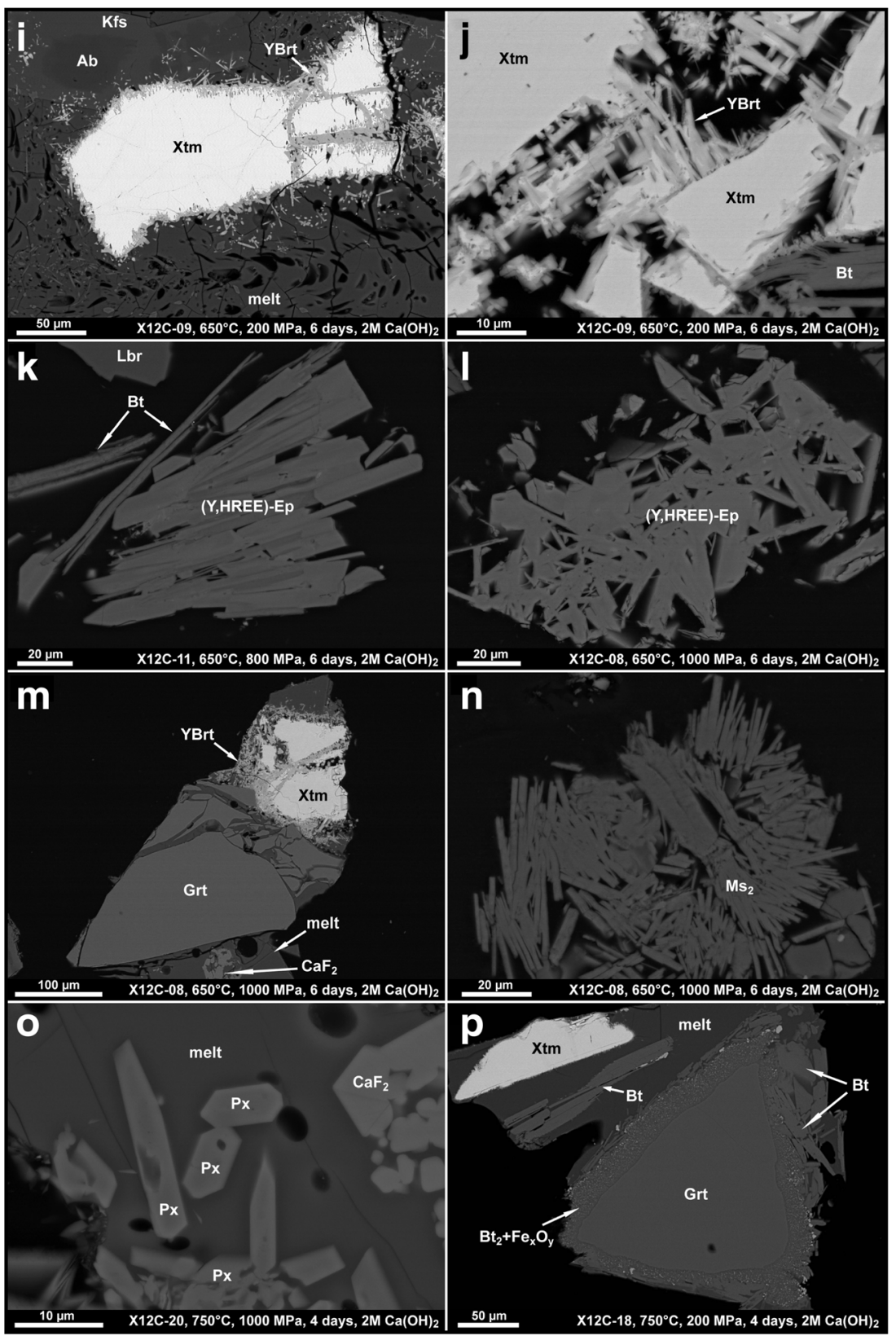

Fig. 10 (continued)

monazite-(Ce), mobility of Th has also been documented by the formation of REE-rich steacyite at $250-350{ }^{\circ} \mathrm{C}$ and 200 $400 \mathrm{MPa}$ by Budzyń et al. (2015) or turkestanite $\left\{(\mathrm{K}, \square)(\mathrm{Ca}, \mathrm{Na})_{2}(\mathrm{Th}, \mathrm{U})\left[\mathrm{Si}_{8} \mathrm{O}_{20}\right] \mathrm{nH}_{2} \mathrm{O}\right\}$ at $450-500{ }^{\circ} \mathrm{C}, 450$ $610 \mathrm{MPa}$ (Budzyń et al. 2011). Natural occurrences of steacyite and turkestanite are known from several alkaline complexes (Pautov et al. 1997, 2004; Kabalov et al. 1998; Petersen et al. 1999; Vilalva and Vlach 2010).

In $\mathrm{Na}_{2} \mathrm{Si}_{2} \mathrm{O}_{5}+\mathrm{H}_{2} \mathrm{O}$ experiments at $650-750{ }^{\circ} \mathrm{C}$, reacted areas in the monazite-(Ce) are characterized by a REE-rich fluorapatite-, Y-rich fluorcalciobritholite- and cheralite-filled lenticular porosity (Fig. 7f, g, $\mathrm{k}$ and l). The lenticular shape of the pores (Fig. 71) suggests preferred dissolution along a certain crystallographic direction (or crystallographic plane) in the monazite-(Ce). Cheralite formation, along inner pore surfaces in the reacted monazite-(Ce), indicates that Th transport occurred over only short distances, whereas REE were mobilized across the pore volumes to form REE-rich fluorapatite and Y-rich fluorcalciobritholite.

The experiments also document the albitization of Kfeldspar grain rims (Figs. $3 \mathrm{i}$ and $7 \mathrm{~b}$ and $\mathrm{j}$ ) via coupled dissolution-reprecipitation (e.g. Putnis 2002, 2009; Norberg et al. 2011, 2013). The re-equilibrated albitic domains in the $\mathrm{K}$-feldspar are characterized by both a micro-porosity and the 
Fig. 11 Al versus $Y+R E E$ diagram (after Petrík et al. 1995), which shows compositional variations in the epidote-group minerals formed due to the alteration of xenotime-(Y) in experiments at $650{ }^{\circ} \mathrm{C}, 800 \mathrm{MPa}$, and $650^{\circ} \mathrm{C}$, $1000 \mathrm{MPa}$

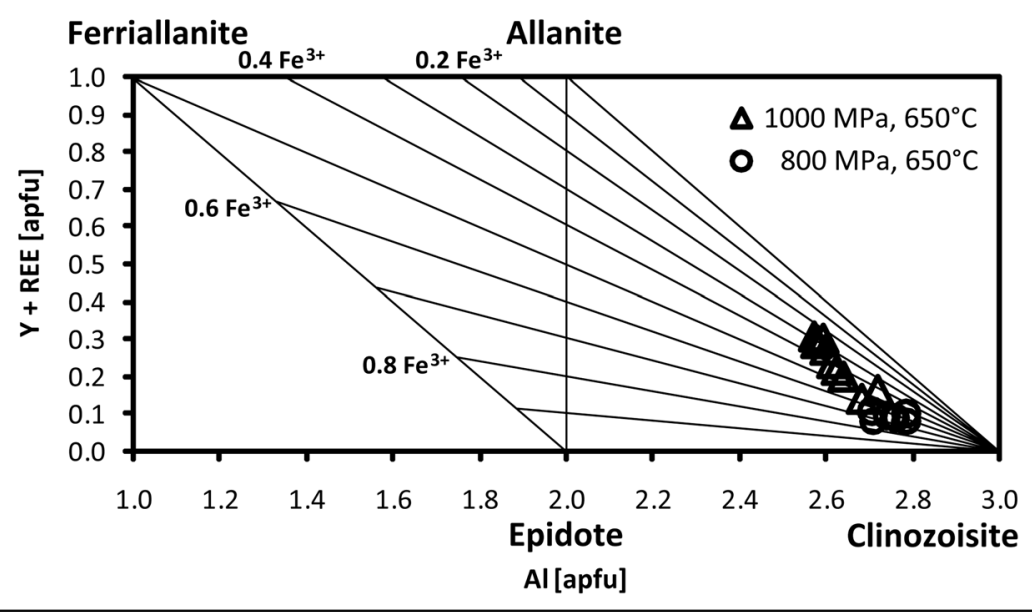

presence of REE-rich fluorapatite or fluorcalciobritholite inclusions. These suggest fluid aided mass transfer of $\mathrm{P}, \mathrm{Ca}$, and REE from the outside the feldspar structure into the albitized regions, which would have then allowed for these inclusions to form.

Previous experimental data have shown that monazite solubility increases in felsic melts under water-saturated conditions (Montel 1993), whereas it is low in peraluminous melts (Montel 1986; Wolf and London 1995). In a series of monazite alteration experiments, Harlov et al. (2011) showed that an increase in the $\mathrm{Al}$ content in the fluid/melt limits the reactivity of monazite. In the experiments from this study, feldspars and micas partially to completely broke down to provide the components for a peraluminous melt in the high temperature experiments (supplementary Tables S7, S16). However no decrease in the reactivity of monazite-(Ce) was seen despite the melt composition. This would imply that the dissolution and reactivity of monazite is mostly related to the actual fluid/melt chemistry with no direct dependence on the $\mathrm{Al}$ content.

The results from this study have implications with regard to monazite Th-U-Pb geochronology. Previous experiments have shown that fluid-aided coupled dissolutionreprecipitation alteration can disturb the $\mathrm{Th}-\mathrm{U}-\mathrm{Pb}$ system in monazite (Teufel and Heinrich 1997; Seydoux-Guillaume et al. 2002; Harlov et al. 2007, 2011; Harlov and Hetherington 2010; Hetherington et al. 2010; Grand'Homme et al. 2016). In experiments utilizing $\mathrm{Na}_{2} \mathrm{Si}_{2} \mathrm{O}_{5}+\mathrm{H}_{2} \mathrm{O}$, partial loss of $\mathrm{Pb}$ in the altered areas of the monazite-(Ce) was seen at 250-350 ${ }^{\circ} \mathrm{C}, 200-400 \mathrm{MPa}$ (Budzyń et al. 2015). Here, for the same mineral assemblage and fluid $\left(\mathrm{Na}_{2} \mathrm{Si}_{2} \mathrm{O}_{5}+\mathrm{H}_{2} \mathrm{O}\right), \mathrm{Pb}$ in altered areas of the monazite- $(\mathrm{Ce})$ is almost completely removed for experiments at $450{ }^{\circ} \mathrm{C}, 200-1000 \mathrm{MPa}$ and $550{ }^{\circ} \mathrm{C}, 200-600 \mathrm{MPa}$ (Fig. 4c and d; supplementary Table S1), which is in good agreement with similar results reported by Williams et al. (2011). These temperatures are far below the diffusional closure temperature for $\mathrm{Pb}$ (i.e. above 800-900 ${ }^{\circ} \mathrm{C}$; Cherniak et al. 2004; Gardes et al. 2006). However in both the $2 \mathrm{M} \mathrm{Ca}(\mathrm{OH})_{2}$ and $\mathrm{Na}_{2} \mathrm{Si}_{2} \mathrm{O}_{5}+\mathrm{H}_{2} \mathrm{O}$ experiments, the unreacted monazite-(Ce) cores show no evidence of having experienced solid-state diffusion over the entire range of temperatures and pressures considered in these experiments. This indicates that significant dissolution, alteration, and partial replacement of the monazite-(Ce) grain by altered monazite-(Ce) or new phases does not affect the composition of the core over the duration of the experiment, even under conditions of $650-750{ }^{\circ} \mathrm{C}$ and subsequent partial melting of the initial mineral mix. Instead, the monazite-(Ce) core (or unaltered domains in patchy zoned grains) retains its original composition, within EPMA detection limits, in an alkalirich fluid environment in a $\mathrm{P}-\mathrm{T}$ window from 450 to at least $750{ }^{\circ} \mathrm{C}$, and 200 to $1000 \mathrm{MPa}$.

\section{Interpretation of the experimental results: runs with xenotime-(Y)}

Similar to the experiments involving monazite-(Ce), the experiments involving xenotime-(Y) indicate that it is highly reactive with both $2 \mathrm{M} \mathrm{Ca}(\mathrm{OH})_{2}$ and $\mathrm{Na}_{2} \mathrm{Si}_{2} \mathrm{O}_{5}+$ $\mathrm{H}_{2} \mathrm{O}$ and that the reaction products are relatively similar to those found for experiments involving monazite-(Ce) over the same P-T range (Tables 1 and 3). Yttrium-rich fluorcalciobritholite always formed either as individual crystals or, more commonly, formed overgrowths on xenotime-(Y) grains indicating relatively high mobilization of $\mathrm{Y}+\mathrm{REE}$, more specifically $\mathrm{Y}+\mathrm{HREE}$. However, $\mathrm{Y}+\mathrm{REE}$ abundances in Y-rich fluorcalciobritholite show no obvious pattern relative to the $\mathrm{P}-\mathrm{T}$ conditions (supplementary Table S11) unlike the apatites from the experiments involving monazite-(Ce). The higher abundance of unaltered xenotime-(Y) grains in the low temperature run products, compared to the paucity of unreacted 

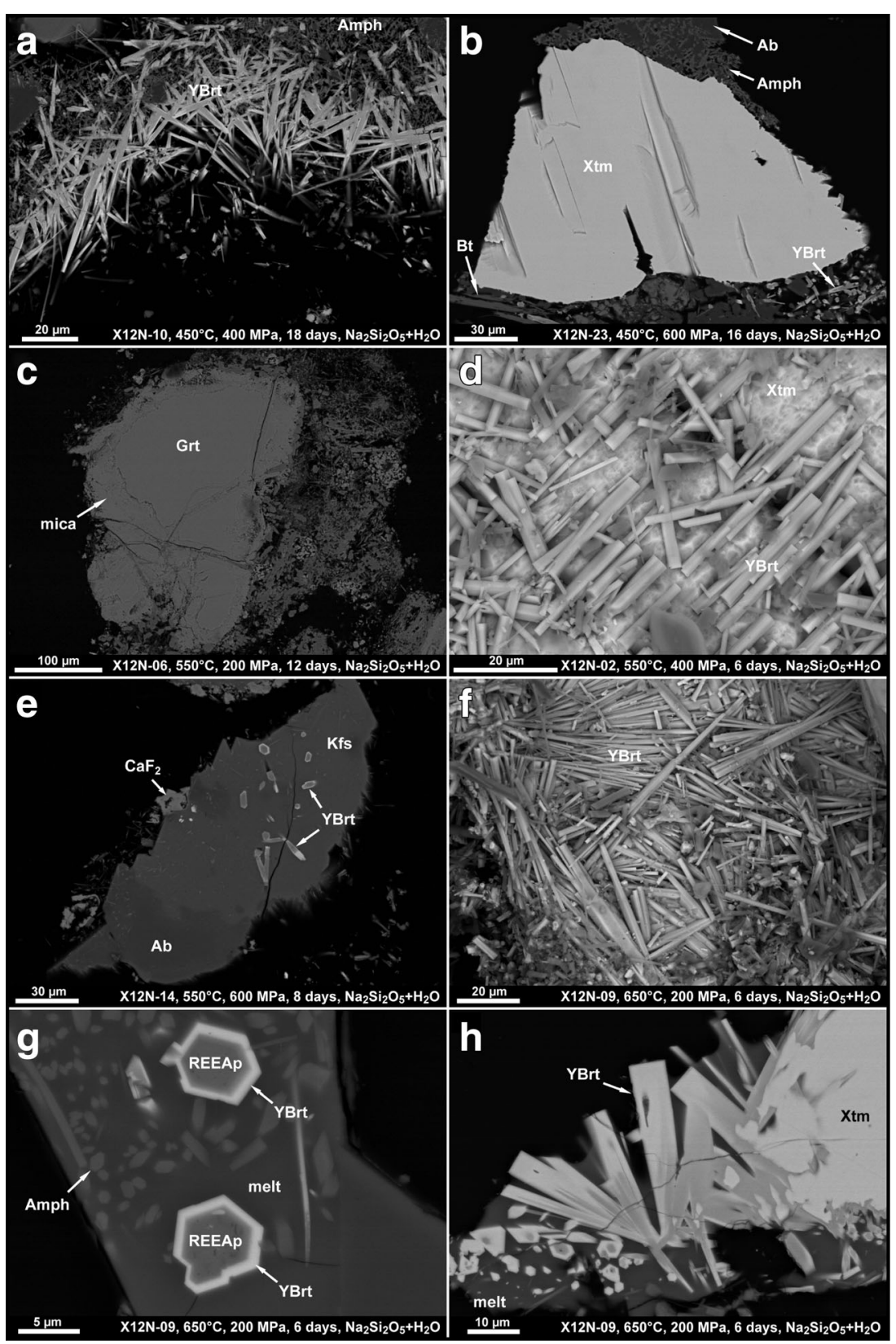

Fig. 12 BSE images of run products from experiments with xenotime(Y) and $\mathrm{Na}_{2} \mathrm{Si}_{2} \mathrm{O}_{5}+\mathrm{H}_{2} \mathrm{O}$; a aggregate of Y-rich fluorcalciobritholite prisms from the experiment at $450{ }^{\circ} \mathrm{C}, 400 \mathrm{MPa}$, and 18 days; b xenotime-(Y) crystal showing delicate dissolution and formation of some Y-rich fluorcalciobritholite crystals $\left(450^{\circ} \mathrm{C}, 600 \mathrm{MPa}, 16\right.$ days); $\mathbf{c}$ altered garnet partially replaced by secondary mica $\left(550^{\circ} \mathrm{C}, 200 \mathrm{MPa}, 12\right.$ days $)$; d hexagonal prismatic crystals of Y-rich fluorcalciobritholite formed on the altered xenotime-(Y) surface $\left(550^{\circ} \mathrm{C}, 400 \mathrm{MPa}, 6\right.$ days); e altered albite almost completely replaced by $\mathrm{K}$-feldspar with inclusions of Y-rich fluorcalciobritholite with REE-rich fluorapatite cores $\left(550^{\circ} \mathrm{C}, 600 \mathrm{MPa}\right.$, 8 days); $\mathbf{f}$ aggregate of hexagonal prismatic, crystals of Y-rich fluorcalciobritholite $\left(650^{\circ} \mathrm{C}, 200 \mathrm{MPa}, 6\right.$ days); $\mathrm{g}$ zoned crystals of REE-rich fluorapatite and Y-rich fluorcalciobritholite in melt $\left(650{ }^{\circ} \mathrm{C}\right.$, $200 \mathrm{MPa}, 6$ days); $\mathbf{h}$ sector-zoned crystals of REE-rich fluorapatite and

Y-rich fluorcalciobritholite, partially overgrowing altered xenotime-(Y) $\left(650{ }^{\circ} \mathrm{C}, 200 \mathrm{MPa}, 6\right.$ days); i altered xenotime-(Y) partially replaced by REE-rich fluorapatite and Y-rich fluorcalciobritholite $\left(650^{\circ} \mathrm{C}, 600 \mathrm{MPa}\right.$, 6 days); j Y-rich fluorcalciobritholite almost completely replacing altered xenotime-(Y) $\left(650^{\circ} \mathrm{C}, 1000 \mathrm{MPa}, 6\right.$ days $)$; $\mathbf{k}$ secondary biotite formed at the expense of garnet breakdown $\left(650{ }^{\circ} \mathrm{C}, 1000 \mathrm{MPa}, 6\right.$ days $)$; I large crystals of REE-rich titanite $\left(650^{\circ} \mathrm{C}, 1000 \mathrm{MPa}, 6\right.$ days); m altered xenotime-(Y) overgrown by Y-rich fluorcalciobritholite $\left(750{ }^{\circ} \mathrm{C}\right.$, $400 \mathrm{MPa}, 4$ days); $\mathbf{n}$ secondary, low-Ti biotite formed at the expense of garnet breakdown $\left(750^{\circ} \mathrm{C}, 600 \mathrm{MPa}, 4\right.$ days); 0 altered xenotime-(Y) overgrown by Y-rich fluorcalciobritholite $\left(750{ }^{\circ} \mathrm{C}, 800 \mathrm{MPa}, 4\right.$ days); $\mathbf{p}$ secondary, low-Ti biotite formed at the expense of garnet breakdown $\left(750{ }^{\circ} \mathrm{C}, 1000 \mathrm{MPa}, 4\right.$ days)

grains in high $\mathrm{P}-\mathrm{T}$ runs, suggests that xenotime-(Y) reactivity is relatively temperature dependent. Some experiments also

document partial replacement of the xenotime-(Y) by Y-rich fluorcalciobritholite, which could be interpreted as having been 


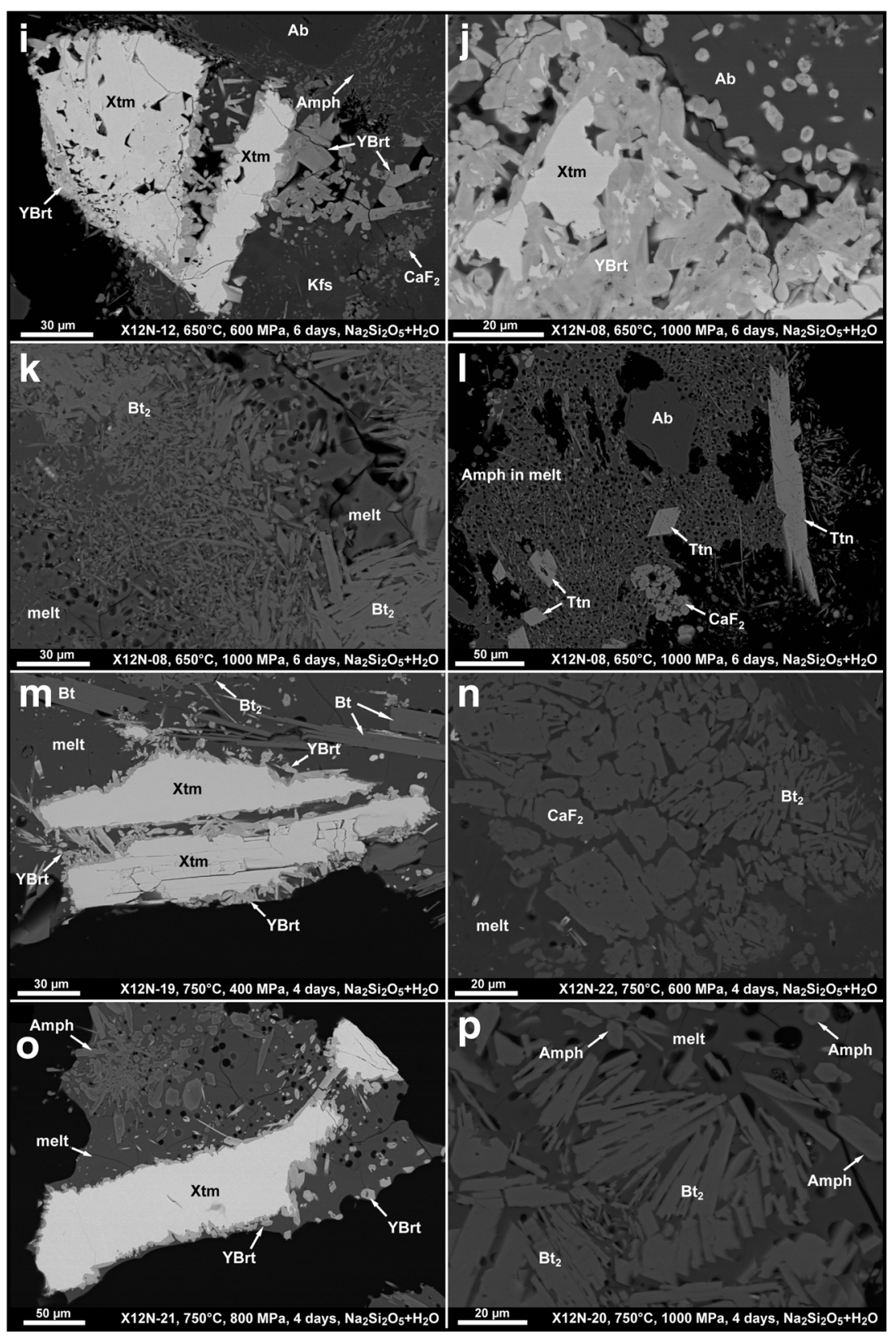

Fig. 12 (continued)

driven, at least partially, by coupled dissolution-reprecipitation (Figs. 10c and $\mathrm{i}$ and $12 \mathrm{i}$ and $\mathrm{m}$ ).

Previous experiments involving the metasomatic alteration of xenotime-( $(\mathrm{Y})$ in the presence of alkali-bearing fluids $\left(\mathrm{Na}_{2} \mathrm{Si}_{2} \mathrm{O}_{5}+\mathrm{H}_{2} \mathrm{O}, \mathrm{NaF}+\mathrm{H}_{2} \mathrm{O}\right)$, along with the addition of $\mathrm{SiO}_{2}, \mathrm{Al}_{2} \mathrm{O}_{3}, \mathrm{ThO}_{2}$, and $\mathrm{ThSiO}_{4}$, has documented enrichment in $\mathrm{ThSiO}_{4}$ in altered areas of the xenotime-(Y) via coupled dissolution-reprecipitation (Harlov and Wirth 2012). More recent experiments at $250-350{ }^{\circ} \mathrm{C}$ and $200-400 \mathrm{MPa}$ have also resulted in the strong alteration of xenotime- $(\mathrm{Y})$ in the presence of $\mathrm{Na}_{2} \mathrm{Si}_{2} \mathrm{O}_{5}+\mathrm{H}_{2} \mathrm{O}$ (Budzyń and Kozub-Budzyń 2015). In the experiments from this study, altered areas within the xenotime-(Y), enriched or depleted in REE, were not observed. This indicates that the components released from the altered xenotime-(Y) were incorporated primarily into the Y-rich fluorcalciobritholite.

Although the $2 \mathrm{M} \mathrm{Ca}(\mathrm{OH})_{2}$ fluid was highly aggressive in all runs, only three runs $\left(550{ }^{\circ} \mathrm{C}, 800 \mathrm{MPa} ; 650{ }^{\circ} \mathrm{C}, 800\right.$ and $1000 \mathrm{MPa}$ ) resulted in the formation of (Y,HREE)-rich epidote, which suggests certain differences in the stability relations between xenotime-(Y) - (Y,HREE)-rich epidote compared to monazite - allanite. The experimental data first indicate that the P-T conditions are a crucial factor in controlling the relative stabilities between xenotime- $(\mathrm{Y})$ and (Y,HREE)rich epidote. Furthermore, the $(\mathrm{Y}+\mathrm{REE})_{2} \mathrm{O}_{3}$ content in (Y,HREE)-rich epidote increases from $2.31 \mathrm{wt} \%$ at 
Fig. 13 BSE image and compositional X-ray maps of xenotime- $(\mathrm{Y})$ altered in a $\mathrm{Na}_{2} \mathrm{Si}_{2} \mathrm{O}_{5}+\mathrm{H}_{2} \mathrm{O}$ fluid from the $\mathrm{X} 12 \mathrm{~N}-08$ run at $650{ }^{\circ} \mathrm{C}$, $1000 \mathrm{MPa}$ over 6 days

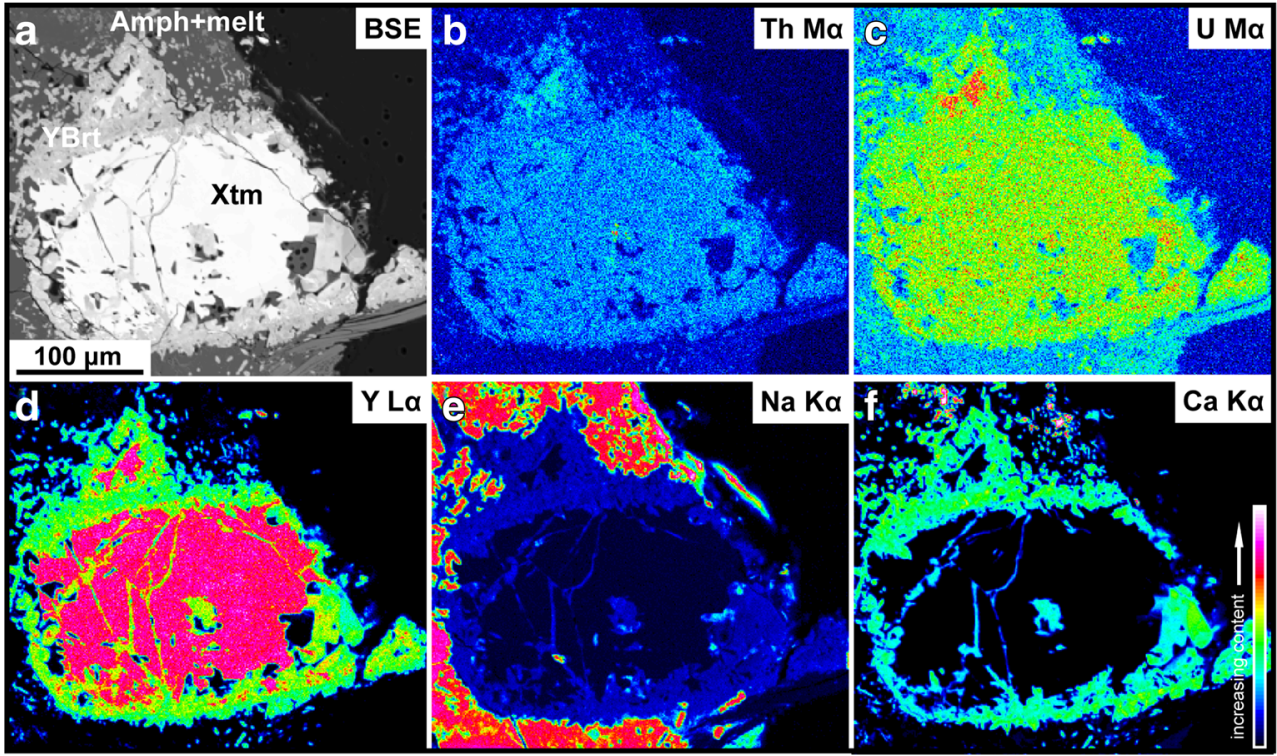

$800 \mathrm{MPa}$ to $5.76 \mathrm{wt} \%$ at $1000 \mathrm{MPa}$ (supplementary Table S12). This suggests that the substitution of these elements is to some degree a function of pressure. However, because of the small crystal size, accurate analyses of (Y,HREE)-rich epidote could only be obtained in two runs. Hence these experimental results should be used only as a guide when applied to natural interpretations.

\section{Monazite - allanite - fluorapatite and xenotime-(Y) - (Y,HREE)-rich epidote - (Y,HREE)-rich fluorapatite assemblages in nature}

The influence of the Ca activity on the stability relations between monazite, allanite, and fluorapatite has been previously described in various rocks of granitic composition (Lee and Dodge 1964; Lee and Bastron 1967; Bea 1996; Bingen et al. 1996; Broska and Siman 1998; Finger et al. 1998; Broska et al. 2000, 2005; Claeson 2002) and metapelites (Janots et al. 2008, 2009). Temperature conditions controlling monazite-allanite phase relations have been constrained to $\sim 400$ $450{ }^{\circ} \mathrm{C}$ in metapelites, where progressive metamorphic reactions involve the breakdown of monazite to form allanite (Smith and Barreiro 1990; Wing et al. 2003; Janots et al. 2006, 2008). In some cases these breakdown reactions were later followed by a reversed reaction resulting in the formation of monazite at the andalusite or kyanite isograd (Wing et al. 2003 ) or under temperature conditions of $\sim 550-650{ }^{\circ} \mathrm{C}$ (Janots et al. 2008; Finger et al. 2016). Thermodynamic modeling by Spear (2010), utilizing Shaw's (1956) average pelite bulk composition, predicted that increasing $\mathrm{CaO}$ from 2.17 to 4.34 wt.\% would shift the allanite-(Ce) to monazite-(Ce) transition from $400{ }^{\circ} \mathrm{C}$ at $200 \mathrm{MPa}$ and $550{ }^{\circ} \mathrm{C}$ at $1000 \mathrm{MPa}$, to $480{ }^{\circ} \mathrm{C}$ at $200 \mathrm{MPa}$ and $750{ }^{\circ} \mathrm{C}$ at $1000 \mathrm{MPa}$ (Fig. 6 in Spear 2010).
The experiments with $2 \mathrm{M} \mathrm{Ca}(\mathrm{OH})_{2}$ confirm that a high $\mathrm{CaO}$ bulk content (10.08 wt.\%, Table 2 ) shifts the stability of allanite-(Ce) towards higher temperatures and pressures up to the limits set by these experiments, i.e. $750{ }^{\circ} \mathrm{C}$ and $1000 \mathrm{MPa}$. In contrast, the experiments with $\mathrm{Na}_{2} \mathrm{Si}_{2} \mathrm{O}_{5}+\mathrm{H}_{2} \mathrm{O}$, also characterized by a high $5.91 \mathrm{wt}$ \% $\mathrm{CaO}$ bulk content, produced no REE-rich epidote or allanite-(Ce) indicating that, depending on the bulk composition, a high $\mathrm{Ca}$ content is not necessarily one of the main factors controlling the monazite-(Ce)-toallanite-(Ce) transition. Spear's (2010) thermodynamic modeling also demonstrated the significant impact of $\mathrm{Al}$, showing that the temperature of the allanite-(Ce)-to-monazite-(Ce) transition increases with a decrease in the $\mathrm{Al}_{2} \mathrm{O}_{3}$ bulk content. Hence, the increased stability of allanite-(Ce) in the experiments to high temperatures might also have been promoted by the low $\mathrm{Al}_{2} \mathrm{O}_{3}$ bulk content [10.04 and $7.74 \mathrm{wt}$.\% in experimental sets (1) and (2), respectively, Table 2] compared to 16.57 wt. $\% \mathrm{Al}_{2} \mathrm{O}_{3}$ in Shaw's average pelite.

However, in general, the whole rock activity of $\mathrm{Na}$, relative to that of $\mathrm{Ca}$, appears to be one of the major factors in controlling the relative stabilities of monazite vs. allanite and xenotime-(Y) vs. (Y,HREE)-rich epidote. For example, in amphibolite-facies Alpine metapelites, both temperature and the bulk $\mathrm{CaO} / \mathrm{Na}_{2} \mathrm{O}$ ratio control the relative stabilities of allanite, monazite, and xenotime-(Y) (Janots et al. 2008). An increase in temperature to above $586{ }^{\circ} \mathrm{C}$, during progressive metamorphism, resulted in the total breakdown of allanite and the formation of monazite and xenotime-(Y) for $\mathrm{CaO} / \mathrm{Na}_{2} \mathrm{O}<$ 0.54 , while allanite remained stable up to $610{ }^{\circ} \mathrm{C}$ for $\mathrm{CaO} /$ $\mathrm{Na}_{2} \mathrm{O}>0.93$ (Janots et al. 2008). In this study, the $\mathrm{CaO} / \mathrm{Na}_{2} \mathrm{O}$ ratios in the experimental runs with monazite- $(\mathrm{Ce})$ and xenotime-(Y) and $2 \mathrm{M} \mathrm{Ca}(\mathrm{OH})_{2}$ were 13.3 and 13.7 , respectively (Table 2), which is much higher than that found to the Alpine metapelites (0.09-3.32 CaO/ $\mathrm{Na}_{2} \mathrm{O}$; Janots et al. 2008). 
Consequently, the allanite-(Ce) stability field was shifted to higher temperatures up to and probably higher than $750{ }^{\circ} \mathrm{C}$. In contrast, neither epidote nor allanite-(Ce) formed in the monazite- $(\mathrm{Ce})$ and xenotime- $(\mathrm{Y}) \mathrm{Na}_{2} \mathrm{Si}_{2} \mathrm{O}_{5}+\mathrm{H}_{2} \mathrm{O}$ experiments with significantly lower $\mathrm{CaO} / \mathrm{Na}_{2} \mathrm{O}$ ratios of 1.0 , though still high concentrations of 5.91 and $5.56 \mathrm{wt} . \% \mathrm{CaO}$, and low concentrations of 7.74 and 9.25 wt. $\% \mathrm{Al}_{2} \mathrm{O}_{3}$ (Table 2), respectively, compared to Spear's (2010) model. The results from these experiments demonstrate that while the $\mathrm{CaO} / \mathrm{Na}_{2} \mathrm{O}$ ratio is important, the total whole rock composition is also important. This implies that the monazite-(Ce)-allanite-(Ce)-fluorapatite thermodynamic model of Spear (2010) should be only applied to those rocks whose whole rock composition approximates Shaw's (1956) average pelite bulk composition.

Compared to numerous studies on monazite, little has been described regarding the alteration of xenotime- $(\mathrm{Y})$ in nature. The fluid-mediated breakdown and replacement of xenotime-(Y) by (Y,HREE)-rich fluorapatite and (Y,HREE)rich epidote have been documented in metamorphosed granitic rocks (Broska et al. 2005). However, the P-T conditions of such alterations remain a matter of some speculation. Fluid-aided, compositional alteration of xenotime-(Y) at $450{ }^{\circ} \mathrm{C}$ has been described in a quartz-muscovite-chlorite schist, which included metamorphic overgrowths on detrital xenotime-(Y) (Rasmussen et al. 2011). In Alpine metapelites, xenotime-(Y) has been described as being replaced by HREE-rich epidote and fluorapatite at $450-528{ }^{\circ} \mathrm{C}$, followed by a reverse reaction at $560-610^{\circ} \mathrm{C}$, depending on the $\mathrm{CaO}$ bulk content and $\mathrm{Ca} / \mathrm{Na}$ ratios (Janots et al. 2008). These observations are confirmed by the breakdown of xenotime-(Y) to (Y,HREE)-rich epidote in the same temperature range in the $2 \mathrm{M} \mathrm{Ca}(\mathrm{OH})_{2}$ experiments (Fig. 2c; Table 3). In general, the results from the xenotime-(Y) experiments in this study could potentially provide important data for petrological constraints regarding xenotime-(Y) breakdown to (Y,HREE)-rich apatite and (Y,HREE)-rich epidote during the formation of the Veporic nappe system in the Tatric unit, Tribeč Mountains (Broska et al. 2014).

The partitioning of REE and actinides between monazite-(Ce), fluorapatite, and fluorcalciobritholite played a significant role in the experiments. In nature, fluorapatite is an important carrier of REE and actinides with increasing metamorphic grade (Bingen et al. 1996; Spear and Pyle 2002; Finger and Krenn 2007; Hansen and Harlov 2007; Krenn et al. 2009, 2012). The results from this study show that REE can substitute into fluorapatite in extensive amounts under conditions replicating medium- to high-grade metamorphism. However, only minor amounts of REE-rich fluorapatite formed in the experiments, whereas fluorcalciobritholite or Y-rich fluorcalciobritholite were the main products due to high $\mathrm{Y}+\mathrm{REE}$ bulk content. In nature, these phases are relatively uncommon, and have been reported in post-magmatic assemblages including britholite-(Y), fluorbritholite-(Y), fluorcalciobritholite, secondary monazite, and REE carbonate minerals formed during low-temperature alteration of primary magmatic fluorapatite and allanite-(Ce) in A-type granites from the Western Carpathians in Slovakia (Uher et al. 2015). Britholites also occur in various alkaline rocks such as alkali granites (Lyalina et al. 2014), pegmatites associated with peralkaline granites (Pekov et al. 2011), nepheline syenites (Liferovich and Mitchell 2006; DumańskaSłowik et al. 2012), and carbonatites (Ahijado et al. 2005; Doroshkevich et al. 2009). The predominance of fluorcalciobritholite or Y-rich fluorcalciobritholite in the products from these experiments appears to have been related to the high percentage of monazite- $(\mathrm{Ce})$ and xenotime- $(\mathrm{Y})$ in the starting mineral mix, as well as the high alkalinity of the starting bulk composition, which includes the fluids used, i.e. $2 \mathrm{M} \mathrm{Ca}(\mathrm{OH})_{2}$ and $\mathrm{Na}_{2} \mathrm{Si}_{2} \mathrm{O}_{5}+\mathrm{H}_{2} \mathrm{O}$. High compositional variations in the REE-rich fluorapatite and fluorcalciobritholite prevent us from making speculations regarding P-T control of REE substitution in the fluorapatite and britholite phases.

The experimental results from this study should be treated with caution when applied to interpretations of natural processes. This is mainly due to the high Y + REE bulk content [8.2-9.4 wt.\% $(\mathrm{Y}+\mathrm{REE})_{2} \mathrm{O}_{3}$; Table 2] due to the predominance of monazite-(Ce) or xenotime-(Y) in the system, the specific whole rock bulk composition of the starting mineral mix + fluids, and the fact that fluids are in excess compared to natural rock systems. Future experiments should more closely replicate the bulk rock composition used by Spear (2010), i.e. 2.17 to 4.34 wt. $\% \mathrm{CaO}$ and 1.73 wt. $\% \mathrm{Na}_{2} \mathrm{O}$. This will require significantly lowering the bulk rock $\mathrm{CaO}$ and $\mathrm{Na}_{2} \mathrm{O}$ and raising the bulk rock $\mathrm{Al}_{2} \mathrm{O}_{3}$ over the $\mathrm{P}-\mathrm{T}$ range considered by Spear (2010). Further lowering of the bulk $\mathrm{CaO} / \mathrm{Na}_{2} \mathrm{O}$ ratio to less than 0.5 , which corresponds to Alpine metapelites of Janots et al. (2008), should also help to increase the stability field of monazite relative to that of allanite and hopefully go some way in helping to experimentally map out the allanitemonazite transition as a function of P-T-X.

Acknowledgments The project was funded by the National Science Center of Poland, grant no. 2011/01/D/ST10/04588. The authors are grateful to I. Petrík and two anonymous reviewers for their valuable and constructive comments, and L. Nasdala for editorial handling the manuscript. B. Budzyń acknowledges W. Heinrich for the access to the experimental laboratories of the Deutsche GeoForschungsZentrum, Potsdam. Scanning electron microscope BSE imaging and analyses were performed in the Institute of Geological Sciences, Jagiellonian University, Kraków. A. Zagórska is appreciated for assistance in sample preparation. The Burnet monazite-(Ce) was provided by M.J. Jercinovic and M.L. Williams.

Open Access This article is distributed under the terms of the Creative Commons Attribution 4.0 International License (http:// creativecommons.org/licenses/by/4.0/), which permits unrestricted use, distribution, and reproduction in any medium, provided you give appropriate credit to the original author(s) and the source, provide a link to the Creative Commons license, and indicate if changes were made. 


\section{References}

Ahijado A, Casillas R, Nagy G, Fernández C (2005) Sr-rich minerals in a carbonatite skarn, Fuerteventura, Canary Islands (Spain). Mineral Petrol 84:107-127

Åmli R, Griffin W (1975) Microprobe analysis of REE minerals using empirical correction factors. Am Mineral 60:599-606

Anderson JL, Bender EE (1989) Nature and origin of Proterozoic A-type granitic magmatism in the southwestern United States of America. Lithos 23:19-52

Andrehs G, Heinrich W (1998) Experimental determination of REE distributions between monazite and xenotime: potential for temperature-calibrated geochronology. Chem Geol 149:83-96

Aranovich LY, Newton RC, Manning CE (2013) Brine-assisted anatexis: experimental melting in the system haplogranite- $\mathrm{H} 2 \mathrm{O}-\mathrm{NaCl}-\mathrm{KCl}$ at deep-crustal conditions. Earth Planet Sci Lett 374:111-120

Bea F (1996) Residence of REE, Y, Th and U in granites and crustal protoliths; implications for the chemistry of crustal melts. J Petrol 37:521-552

Bingen B, Demaiffe D, Hertogen J (1996) Redistribution of rare earth elements, thorium, and uranium over accessory minerals in the course of amphibolite to granulite facies metamorphism: the role of apatite and monazite in orthogneisses from southwestern Norway. Geochim Cosmochim Acta 60(8):1341-1354

Broska I, Petrík I (2015) Variscan thrusting in I- and S-type granitic rocks of the Tribeč Mountains, Western Carpathians (Slovakia): evidence from mineral compositions and monazite dating. Geol Carpath 66(6):455-471

Broska I, Siman P (1998) The breakdown of monazite in the WestCarpathian Veporic orthogneisses and Tatric granites. Geol Carpath 49:161-167

Broska I, Petrík I, Williams T (2000) Coexisting monazite and allanite in peraluminous granitoids of the Tribeč Mountains, Western Carpathians. Am Mineral 85:22-32

Broska I, Williams CT, Janák M, Nagy G (2005) Alteration and breakdown of xenotime-(Y) and monazite-(Ce) in granitic rocks of the Western Carpathians, Slovakia. Lithos 82:71-83

Broska I, Uher P, Krogh Ravna E, Janák M, Kullerud K, Luptáková J, Bačík P, Vojtko P, Madarás J (2014) Apatite stability in examples from low- to high-metamorphic conditions. In: Bagiński B, Grafka O, Matyszczak W, Macdonald R (eds) Workshop on accessory minerals. University of Warsaw, September, 2014, pp 13-15

Budzyń B, Jastrzębski M (2016) Monazite stability and the maintenance of Th-U-total $\mathrm{Pb}$ ages during post-magmatic processes in granitoids and host metasedimentary rocks: a case study from the Sudetes (SW Poland). Geol Quat 60(1):106-123

Budzyń B, Kozub-Budzyń GA (2015) The stability of xenotime in high $\mathrm{Ca}$ and $\mathrm{Ca}-\mathrm{Na}$ systems, under experimental conditions of 250 $350{ }^{\circ} \mathrm{C}$ and $200-400 \mathrm{MPa}$ : the implications for fluid-mediated low-temperature processes in granitic rocks. Geol Quat 59(2):316324

Budzyń B, Hetherington CJ, Williams ML, Jercinovic MJ, Michalik M (2010) Fluid-mineral interactions and constraints on monazite alterations during metamorphism. Mineral Mag 74(4):633-655

Budzyń B, Harlov DE, Williams ML, Jercinovic MJ (2011) Experimental determination of stability relations between monazite, fluorapatite, allanite, and REE-epidote as a function of pressure, temperature, and fluid composition. Am Mineral 96:1547-1567

Budzyń B, Konečný P, Kozub-Budzyń GA (2015) Stability of monazite and disturbance of the $\mathrm{Th}-\mathrm{U}-\mathrm{Pb}$ system under experimental conditions of $250-350^{\circ} \mathrm{C}$ and 200-400 MPa. Ann Soc Geol Pol 85:405424

Cherniak DJ (2006) $\mathrm{Pb}$ and rare earth elements diffusion in xenotime. Lithos 88:1-14
Cherniak DJ, Watson EB, Grove M, Harrison TM (2004) Pb diffusion in monazite: a combined RBS/SIMS study. Geochim Cosmochim Acta 68:829-840

Chew DM, Spikings RA (2015) Geochronology and thermochronology using apatite: time and temperature, lower crust to surface. Elements 11:189-194

Claeson DT (2002) Stability of REE-bearing minerals in a metaluminous leucotonalite from the Eriksberg gabbro, Transscandinavian Igneous Belt, Sweden. Neues Jb Miner Abh 177:277-291

Darling JR, Storey CD, Engi M (2012) Allanite U-Th-Pb geochronology by laser ablation ICPMS. Chem Geol 292-293:103-115

Doroshkevich AG, Viladkar AG, Ripp GS, Burtseva MV (2009) Hydrothermal REE mineralization in the Amba Dongar carbonatite complex, Gujarat, India. Can Mineral 47:1105-1116

Dumańska-Słowik M, Budzyń B, Heflik W, Sikorska M (2012) Stability relationships of REE-bearing phosphates in an alkali-rich system (nepheline syenite from the Mariupol Massif, SE Ukraine). Acta Geol Pol 62:247-265

Finger F, Krenn E (2007) Three metamorphic monazite generations in a high-pressure rock from the Bohemian Massif and the potentially important role of apatite in stimulating polyphase monazite growth along a PT loop. Lithos 95:103-115

Finger F, Broska I, Roberts MP, Schermaier A (1998) Replacement of primary monazite by apatite-allanite-epidote coronas in an amphibolite facies granite gneiss from the eastern Alps. Am Mineral 83: $248-258$

Finger F, Krenn E, Schulz B, Harlov D, Schiller D (2016) "Satellite monazites" in polymetamorphic basement rocks of the Alps: their origin and petrological significance. Am Mineral 101:1094-1103

Förster HJ (1998) The chemical composition of REE-Y-Th-U-rich accessory minerals in peraluminous granites of the ErzgebirgeFichtelgebirge region, Germany, Part I: the monazite-(Ce)brabantite solid solution series. Am Mineral 83:259-272

Förster HJ, Rhede D, Stein HJ, Romer RL, Tischendorf G (2012) Paired uraninite and molybdenite dating of the Königshain granite: implications for the onset of late-Variscan magmatism in the Lausitz Block. Int J Earth Sci (Geol Rundsch) 101:57-67

Gardes E, Jaoul O, Montel JM, Seydoux-Guillaume AM, Wirth R (2006) $\mathrm{Pb}$ diffusion in monazite: an experimental study of $\mathrm{Pb}^{2+}+\mathrm{Th}^{4+} \leftrightarrow$ $2 \mathrm{Nd}^{3+}$ interdiffusion. Geochim Cosmochim Acta 70:2325-2336

Grand'Homme A, Janots E, Seydoux-Guillaume AM, Guillaume D, Bosse V, Magnin V (2016) Partial resetting of the U-Th-Pb systems in experimentally altered monazite: nanoscale evidence of incomplete replacement. Geology 44(6):431-434

Gratz R, Heinrich W (1997) Monazite-xenotime thermobarometry: experimental calibration of the miscibility gap in the binary system $\mathrm{CePO}_{4}-\mathrm{YPO}_{4}$. Am Mineral 82:772-780

Gregory CJ, Rubatto D, Allen CM, Williams IS, Hermann J, Ireland T (2007) Allanite micro-geochronology: A LA-ICP-MS and SHRIMP U-Th-Pb study. Chem Geol 245:162-182

Hansen EC, Harlov DE (2007) Whole-rock, phosphate, and silicate compositional trends across an amphibolite- to granulite-facies transition, Tamil Nadu, India. J Petrol 48:1641-1680

Harlov DE (2015) Apatite: a fingerprint for metasomatic processses. Elements 11:171-176

Harlov DE, Hetherington CJ (2010) Partial high-grade alteration of monazite using alkali-bearing fluids: experiment and nature. Am Mineral 95:1105-1108

Harlov DE, Milke R (2002) Stability of corundum + quartz relative to kyanite and sillimanite at high temperature and pressure. Am Mineral 87:424-432

Harlov DE, Wirth R (2012) Experimental incorporation of Th into xenotime at middle to lower crustal P-T utilizing alkali-bearing fluids. Am Mineral 97:641-652

Harlov DE, Wirth R, Hetherington CJ (2007) The relative stability of monazite and huttonite at $300-900{ }^{\circ} \mathrm{C}$ and $200-1000 \mathrm{MPa}$ : 
metasomatism and the propagation of metastable mineral phases. Am Mineral 92:1652-1664

Harlov DE, Wirth R, Hetherington CJ (2011) Fluid-mediated partial alteration of monazite: the role of fluids during apparent solid state element mass transfer. Contrib Mineral Petrol 162:329-348

Heinrich W, Andrehs G, Franz G (1997) Monazite-xenotime miscibility gap thermometry. I. an empirical calibration. J Metamorph Geol 15: $3-16$

Hetherington CJ, Jercinovic MJ, Williams ML, Mahan K (2008) Understanding geologic processes with xenotime: composition, chronology, and a protocol for electron microprobe microanalysis. Chem Geol 254:133-147

Hetherington CJ, Harlov DE, Budzyń B (2010) Experimental initiation of dissolution-reprecipitation reactions in monazite and xenotime: the role of fluid composition. Mineral Petrol 99:165-184

Janots E, Negro F, Brunet F, Goffé B, Engi M, Bouybaouène ML (2006) Evolution of the REE mineralogy in HP-LT metapelites of the Sebtide complex, Rif, Morocco: monazite stability and geochronology. Lithos 87:214-234

Janots E, Brunet F, Goffé B, Poinssot C, Burchard M, Cemic L (2007) Thermochemistry of monazite-(La) and dissakisite-(La): implications for monazite and allanite stability in metapelites. Contrib Mineral Petrol 154:1-14

Janots E, Engi M, Berger A, Allaz J, Schwarz JO, Spandler C (2008) Prograde metamorphic sequence of REE minerals in pelitic rocks of the Central Alps: implications for allanite-monazite-xenotime phase relations from 250 to $610^{\circ} \mathrm{C}$. J Metamorph Geol 26:509-526

Janots E, Engi M, Rubatto D, Berger A, Gregory C, Rahn M (2009) Metamorphic rates in collisional orogeny from in situ allanite and monazite dating. Geology 37:11-14

Janoušek V, Farrow CM, Erban V (2006) Interpretation of whole-rock geochemical data in igneous geochemistry: introducing Geochemical Data Toolkit (GCDkit). J Petrol 47:1255-1259

Johannes W (1973) Eine vereinfachte Piston-Zylinder-Apparatur hoher Genauigkeit. Neues Jb Miner Monat 7(8):337-351

Johannes W, Bell PM, Mao HK, Boettcher AL, Chipman EW, Hays JF, Newton RC, Siefert F (1971) An interlaboratory comparison of piston cylinder pressure calibration using the albite-breakdown reaction. Contrib Mineral Petrol 32:24-38

Kabalov YK, Sokolova EV, Pautov LA, Schneider J (1998) Crystal structure of a new mineral turkestanite: a calcium analogue of steacyite. Crystallog Rep 43:584-588 [Translated from Russian in: Kristallografiya+ 43(4):632-636]

Krenn E, Janák M, Finger F, Broska I, Konečný P (2009) Two types of metamorphic monazite with contrasting $\mathrm{La} / \mathrm{Nd}$, Th, and $\mathrm{Y}$ signatures in an ultrahigh-pressure metapelite from the Pohorje Mountains, Slovenia: indications for pressure-dependent REE exchange between apatite and monazite? Am Mineral 94:801-815

Krenn E, Harlov DE, Finger F, Wunder B (2012) LREE-redistribution among fluorapatite, monazite, and allanite at high pressures and temperatures. Am Mineral 97:1881-1890

Leake BE, Woolley AR, Arps CES, Birch WD, Gilbert MC, Grice JD, Hawthorne FC, Kato A, Kisch HJ, Krivovichev VG, Linthout K, Laird J, Mandarino JA, Maresch WV, Nickel EH, Rock NMS, Schumacher JC, Smith DC, Stephenson NCN, Ungaretti L, Whittaker EJW, Youzhi G (1997) Nomenclature of amphiboles: report of the subcommittee on amphiboles of the international mineralogical association, commission on new minerals and mineral names. Can Mineral 35:219-246

Lee DE, Bastron H (1967) Fractionation of rare-earth elements in allanite and monazite as related to geology of the Mt. Wheeler mine area, Nevada. Geochim Cosmochim Acta 31:339-356

Lee DE, Dodge FCW (1964) Accessory minerals in some granitic rocks in California and Nevada as a function of calcium content. Am Mineral 49:1660-1669
Liferovich RP, Mitchell RH (2006) Apatite-group minerals from nepheline syenite, Pilansberg alkaline complex, South Africa. Mineral Mag 70:463-484

Linthout $\mathrm{K}$ (2007) Tripartite division of the system $2 \mathrm{REEPO}_{4}$ $\mathrm{CaTh}\left(\mathrm{PO}_{4}\right)_{2}-2 \mathrm{ThSiO}_{4}$, discreditation of brabantite, and recognition of cheralite as the name for members dominated by $\mathrm{CaTh}\left(\mathrm{PO}_{4}\right)_{2}$. Can Mineral 45:503-508

Lo Pò D, Braga R, Massonne HJ, Molli G, Montanini A, Theye T (2016) Fluid-induced breakdown of monazite in medium-grade metasedimentary rocks of the Pontremoli basement (Northern Apennines, Italy). J Metamorph Geol 34:63-84

Lyalina LM, Zozulya DR, Savchenko YE, Tarasov MP, Selivanova EA, Tarasova E (2014) Fluorbritholite-(Y) and Yttrialite-(Y) from Silexites of the Keivy Alkali Granites, Kola Peninsula. Geol Ore Deposits 56:589-602

Majka J, Budzyń B (2006) Monazite breakdown in metapelites from Wedel Jarlsberg Land, Svalbard - preliminary results. Mineral Pol 37(1):61-69

Majka J, Pršek J, Budzyń B, Bačík P, Barker A, Łodziński M (2011) Fluorapatite-hingganite-( $(\mathrm{Y})$ coronas as products of fluid induced xenotime-(Y) breakdown in the Skoddefjellet pegmatite (Svalbard). Mineral Mag 75:159-167

Montel JM (1986) Experimental determination of the solubility of Cemonazite in $\mathrm{SiO}_{2}-\mathrm{Al}_{2} \mathrm{O}_{3}-\mathrm{K}_{2} \mathrm{O}-\mathrm{Na}_{2} \mathrm{O}$ melts at $800{ }^{\circ} \mathrm{C}, 2 \mathrm{kbar}$, under $\mathrm{H}_{2} \mathrm{O}$-saturated conditions. Geology 14:659-662

Montel JM (1993) A model for monazite/melt equilibrium and application to the generation of granitic magmas. Chem Geol 110:127-146

Nekvasil H (1988) Calculated effect of anorthite component on the crystallization paths of $\mathrm{H}_{2} \mathrm{O}$-undersaturated haplogranitic melts. Am Mineral 73:966-981

Norberg N, Neusser G, Wirth R, Harlov D (2011) Microstructural evolution during experimental albitization of K-rich alkali feldspar. Contrib Mineral Petrol 162:531-546

Norberg N, Harlov D, Neusser G, Wirth R, Rhede D, Morales L (2013) Experimental development of patch perthite from synthetic cryptoperthite: microstructural evolution and chemical re-equilibration. Am Mineral 98:1429-1441

Ondrejka M, Uher P, Putiš M, Broska I, Bačík P, Konečný P, Schmiedt I (2012) Two-stage breakdown of monazite by post-magmatic and metamorphic fluids: an example from the Veporic orthogneiss, Western Carpathians, Slovakia. Lithos 142-143:245-255

Pan Y, Fleet ME (2002) Composition of the apatite-group minerals: substitution mechanisms and controlling factors. In: Kohn MJ, Rakovan J, Hughes JM (Eds) Phosphates: geochemical, geobiological, and materials importance. Rev Mineral Geochem 48:13-49

Pasero M, Kampf A, Ferraris C, Pekov IV, Rakovan J, White TJ (2010) Nomenclature of the apatite supergroup minerals. Eur J Mineral 22: 163-179

Pautov LA, Agakhanov AA, Sokolova EV, Kabalov YK (1997) Turkestanite $-\mathrm{Th}(\mathrm{Ca}, \mathrm{Na})_{2}\left(\mathrm{~K}_{1-\mathrm{x}}, \square_{\mathrm{x}}\right)\left(\mathrm{Si}_{8} \mathrm{O}_{20}\right) \cdot \mathrm{nH}_{2} \mathrm{O}$ : A new mineral with Si-O rings. Zap Vses Mineral O-va 126:45-55

Pautov LA, Agakhanov AA, Sokolova E, Hawthorne FC (2004) Maleevite, $\mathrm{BaB}_{2} \mathrm{Si}_{2} \mathrm{O}_{8}$, and pekovite, $\mathrm{SrB}_{2} \mathrm{Si}_{2} \mathrm{O}_{8}$, new mineral species from the Dara-i-Pioz alkaline massif, Northern Tajikistan: description and crystal structure. Can Mineral 42:107-119

Pekov IV, Zubkova NV, Chukanov NV, Husdal TA, Zadov E, Pushcharovsky DY (2011) Fluorbritholite-(Y), (Y, Ca, Ln $)_{5}[(\mathrm{Si}$, P) $\left.\mathrm{O}_{4}\right]_{3} \mathrm{~F}$, a new mineral of the britholite group. Neues $\mathrm{Jb}$ Miner Abh 188(2):191-197

Petersen OV, Johnsen O, Micheelsen HI (1999) Turkestanite from the Ilímaussaq alkaline complex, South Greenland. Neues Jb Miner Monat 9:424-432

Petrík I, Broska I, Lipka J, Siman P (1995) Granitoid Allanite-(Ce) substitution relations, redox conditions and REE distributions (on an Example of I-Type Granitoids, Western Carpathians, Slovakia). Geol Carpath 46:79-94 
Petrík I, Konečný P, Kováčik M, Holický I (2006) Electron microprobe dating of monazite from the Nizke Tatry Mountains orthogneisses (Western Carpathians, Slovakia). Geol Carpath 57:227-242

Putnis A (2002) Mineral replacement reactions: from macroscopic observations to microscopic mechanisms. Mineral Mag 66:689-708

Putnis A (2009) Mineral replacement reactions. In: Putirka KD, Tepley III FJ (Eds) Minerals, inclusions and volcanic processes. Rev Mineral Geochem 70:87-124

Putnis A, Austrheim H (2012) Mechanisms of metasomatism and metamorphism on the local mineral scale: the role of dissolutionreprecipitation during mineral re-equilibration. In: Harlov DE, Austrheim H (eds) Metasomatism and the chemical transformation of rock, lecture notes in earth system sciences. Springer, Berlin, pp $141-170$

Pyle JM, Spear FS, Rudnick RL, McDonough WF (2001) Monazitexenotime-garnet equilibrium in metapelites and a new monazitegarnet thermometer. J Petrol 42:2083-2107

Rakovan J (2002) Growth and surface properties of apatite. In: Kohn MJ, Rakovan J, Hughes JM (Eds) Phosphates: geochemical, geobiological, and materials importance. Rev Mineral Geochem 48:51-86

Rakovan J, Reeder RJ (1996) Intracrystalline rare earth element distributions in apatite: surface structural influences on incorporation during growth. Geochim Cosmochim Acta 60:4435-4445

Rasmussen B (2005) Radiometric dating of sedimentary rocks: the application of diagenetic xenotime geochronology. Earth-Sci Rev 68: 197-243

Rasmussen B, Muhling JR (2007) Monazite begets monazite: evidence for dissolution of detrital monazite and reprecipitation of syntectonic monazite during low-grade regional metamorphism. Contrib Mineral Petrol 154:675-689

Rasmussen B, Fletcher IR, Muhling JR (2011) Response of xenotime to prograde metamorphism. Contrib Mineral Petrol 162:1259-1277

Seydoux-Guillaume AM, Paquette JL, Wiedenbeck M, Montel JM, Heinrich W (2002) Experimental resetting of the U-Th-Pb systems in monazite. Chem Geol 191:165-181

Shaw DM (1956) Geochemistry of pelitic rocks. Part III: major elements and general geochemistry. Geol Soc Am Bull 67:919-934

Smith HA, Barreiro B (1990) Monazite U-Pb dating of staurolite grade metamorphism in pelitic schists. Contrib Mineral Petrol 105:602-615
Spear FS (2010) Monazite-allanite phase relations in metapelites. Chem Geol 279:55-62

Spear FS, Pyle JM (2002) Apatite, Monazite, and Xenotime in Metamorphic Rocks. In: Kohn MJ, Rakovan J, Hughes JM (Eds) Phosphates: geochemical, geobiological, and materials importance. Rev Mineral Geochem 48:293-335

Teufel S, Heinrich W (1997) Partial resetting of the U-Pb isotope system in monazite through hydrothermal experiments: an SEM and U-Pb isotope study. Chem Geol 137:273-281

Uher P, Ondrejka M, Bačík P, Broska I, Konečný P (2015) Britholite, monazite, REE carbonates, and calcite: Products of hydrothermal alteration of allanite and apatite in A-type granite from Stupné, Western Carpathians, Slovakia. Lithos 236-237:212-225

Vilalva FCJ, Vlach SRF (2010) Major- and trace-element composition of REE-rich turkestanite from peralkaline granites of the Morro Redondo Complex, Graciosa Province, south Brasil. Mineral Mag 74:645-658

Villa IM, Williams ML (2013) Geochronology of Metasomatic Events. In: Harlov DE, Austrheim H (eds) Metasomatism and the chemical transformation of rock, lecture notes in earth system sciences. Springer, Berlin, pp 171-202

Washington HS (1917) Chemical analyses of igneous rocks. United States Geological Survey Professional Paper 99, 1201 p.

Whitney DL, Evans BW (2010) Abbreviations for names of rock-forming minerals. Am Mineral 95:185-187

Williams ML, Jercinovic MJ, Hetherington CJ (2007) Microprobe monazite geochronology: understanding geologic processes by integrating composition and chronology. Annu Rev Earth Planet Sci 35: $137-175$

Williams ML, Jercinovic MJ, Harlov DE, Budzyń B, Hetherington CJ (2011) Resetting monazite ages during fluid-related alteration. Chem Geol 283:218-225

Wing B, Ferry JM, Harrison TM (2003) Prograde destruction and formation of monazite and allanite during contact and regional metamorphism of pelites: petrology and geochronology. Contrib Mineral Petrol 145:228-250

Wolf MB, London D (1995) Incongruent dissolution of REE- and Sr-rich apatite in peraluminous granitic liquids: Differential apatite, monazite, and xenotime solubilities during anatexis. Am Mineral 80:765-775 